THE RELATIONSHIP BETWEEN

THE HIGH SCHOOL PRINCIPAL'S USE OF POWER AND

THE TEACHERS' SELF-PERCEPTION OF PROFESSIONALISM

A Dissertation
presented to
the Faculty of the Graduate School
at the University of Missouri - Columbia
In Partial Fulfillment
of the Requirements for the Degree
Doctor of Education
Mr. Cynthia MacGregor, Dissertation Supervisor
MAY 2015
DIS WILLIAM GRAHAM




\section{APPROVAL PAGE}

The undersigned, appointed by the dean of the Graduate School, have examined the dissertation entitled

\section{THE RELATIONSHIP BETWEEN THE HIGH SCHOOL PRINCIPAL'S USE OF POWER AND THE TEACHERS' SELF-PERCEPTION OF PROFESSIONALISM}

presented by Travis W. Graham

a candidate for the degree of doctor of education, and hereby certify that, in their opinion, is worthy of acceptance.

Cynthia MacGregor, Ed. D.

Robert Watson, Ed.D.

William J. Agnew, Ph.D.

Kevin Kopp, Ed.D. 


\section{DEDICATION}

I dedicate this dissertation to the love of my life, Jamie Graham. Without her patience, understanding, support, encouragement, and most of all love, the completion of this work would not have been possible. 


\section{ACKNOWLEDGEMENTS}

The doctoral journey has been one filled with great growth and many challenges, both personally and professionally. I would like to first thank my committee members for their guidance and support. Their input and feedback through the writing process provided me opportunity to gain perspective and insight into the research process and enriched my experience greatly. I would like to say a special thank you to Dr. Cynthia MacGregor who sparked my interest in research several years ago while I was working on my master's degree in educational administration. Dr. MacGregor's passion for excellence and ability to encourage and support scholarly exploration provided me with the courage to move forward in pursuing my doctorate. I would also like to thank Dr. Robert Watson for his insight and personalization of the educational process.

Furthermore, I would like to express my appreciation for those who were the "iron-that-sharpens-iron," and who shared with me their many gifts and talents on this journey: Katy Rudolph, Jeremy Schenk, David Schmitz, Garrett Prevo, Jeremey Wolfe, and Kevin Elliott. Thank you for your willingness to share your experiences with me and for your support and encouragement through the doctoral program. I am blessed and have been made a better leader because of the time I have spent with each of you and look forward to keeping in touch. 


\section{TABLE OF CONENTS}

ACKNOWLEDGMENTS ii

LIST OF TABLES viii

LIST OF FIGURES ix

ABSTRACT

\section{CHAPTER}

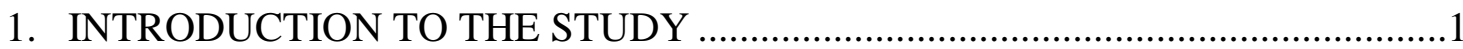

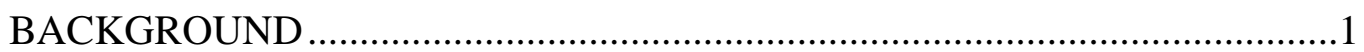

STATEMENT OF THE PROBLEM..................................................................

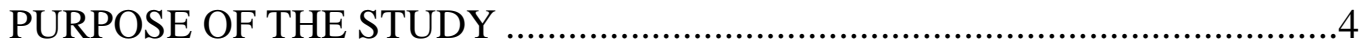

RESEARCH QUESTIONS ……………………………….....................

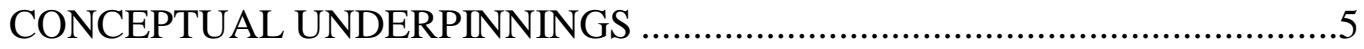

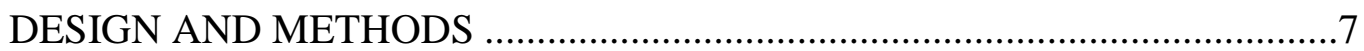

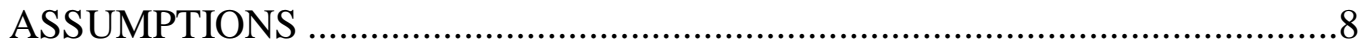

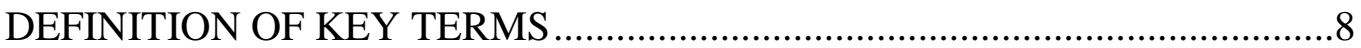

SIGNIFICANCE OF THE STUDY ……………………..............................12

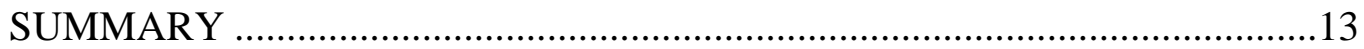

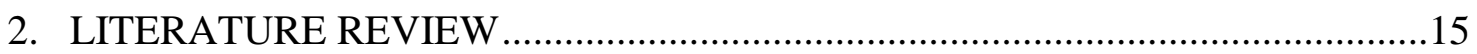

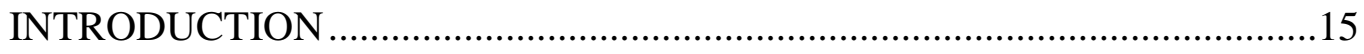

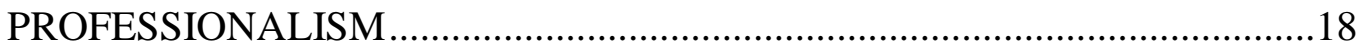

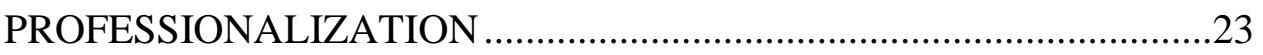

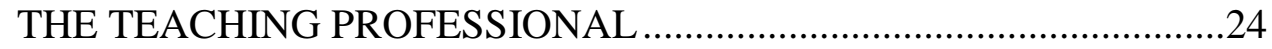


DEPROFESSIONALIZATION.

POWER

BASES OF POWER ....................................................................... 31

THE EXERCISE OF POWER...........................................................34

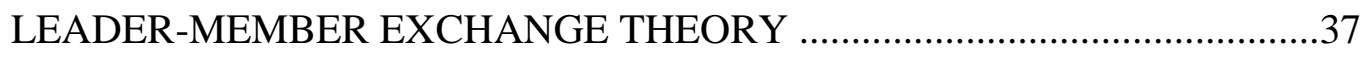

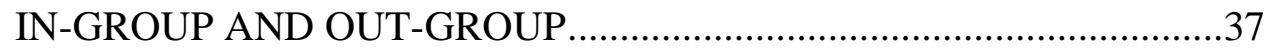

LMX-THEORY AND PROFESSIONALISM .......................................39

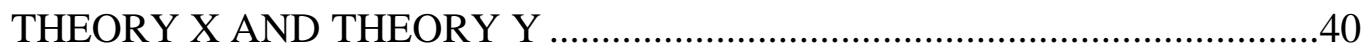

THEORY X/Y AND PROFESSIONALISM ....................................41

PRINCIPALS AND POWER ..............................................................42

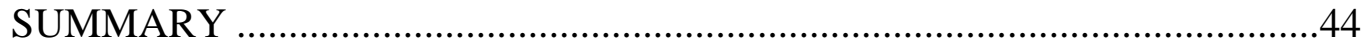

3. RESEARCH DESIGN AND METHODOLOGY .............................................47

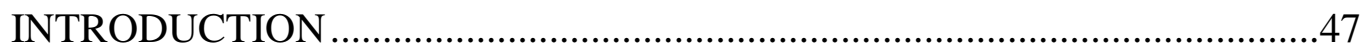

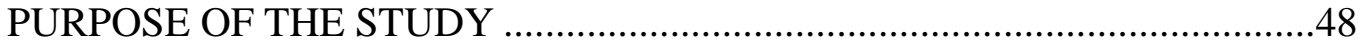

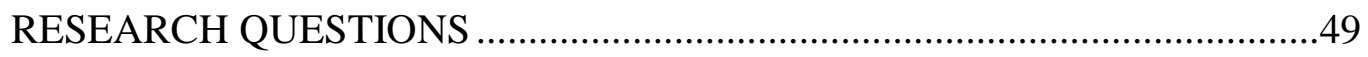

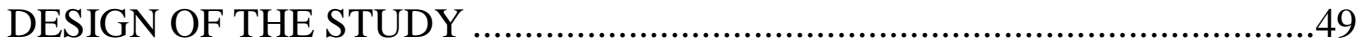

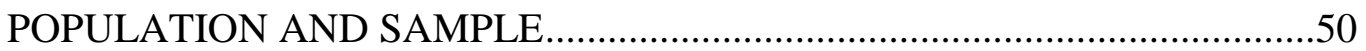

DATA COLLECTION AND INSTRUMENTATION ..................................51

DATA COLLECTION AND PROCEDURES .....................................51

SURVEY INSTRUMENTS.....................................................52

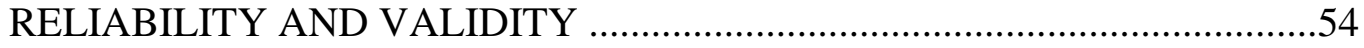

HUMAN SUBJECTS PROTECTION ....................................................55

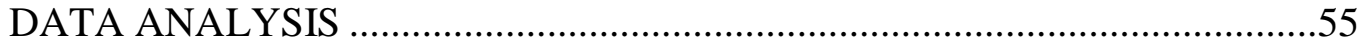


RESEARCH QUESTION ONE ………………………………….......56

RESEARCH QUESTION TWO.........................................................56

RESEARCH QUESTION THREE.....................................................56

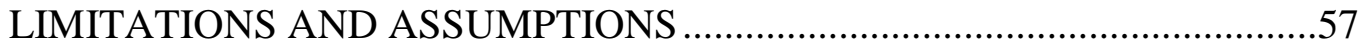

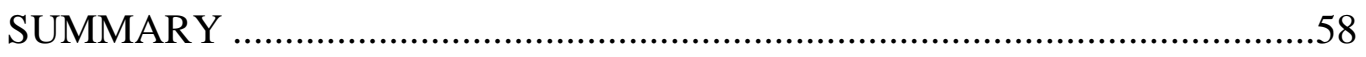

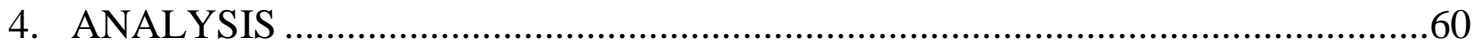

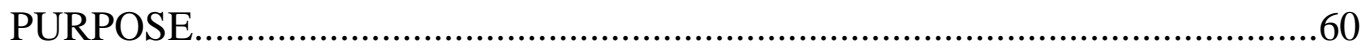

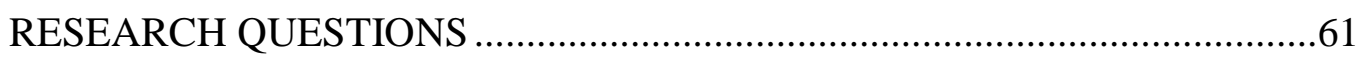

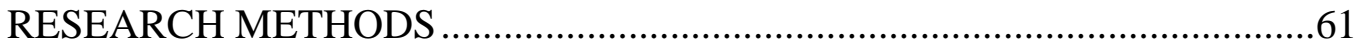

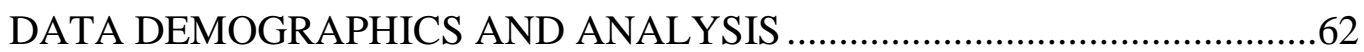

DATA RESULTS FOR RESEARCH QUESTION ONE...................................65

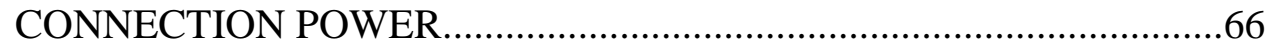

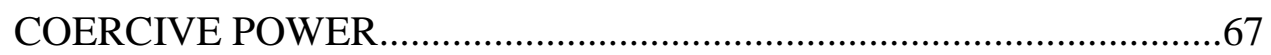

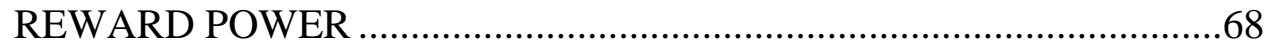

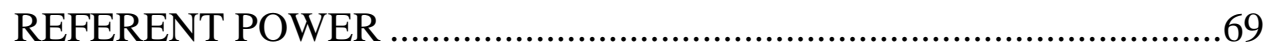

INFORMATION POWER ....................................................................

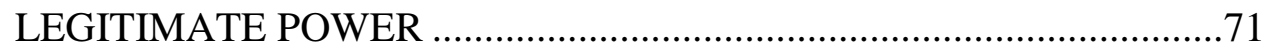

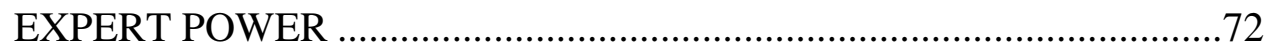

SUMMARY FOR RESEARCH QUESTIONS ONE ................................73

DATA RESULTS FOR RESEARCH QUESTION TWO …………...................74

COMMITMENT TO CHANGE AND IMPROVEMENT .........................75

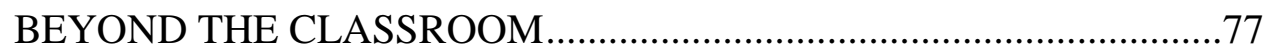

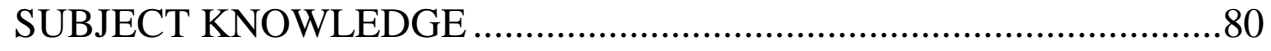




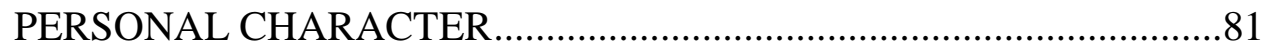

SUMMARY FOR RESEARCH QUESTIONS TWO................................83

DATA RESULTS FOR RESEARCH QUESTION THREE .................................86

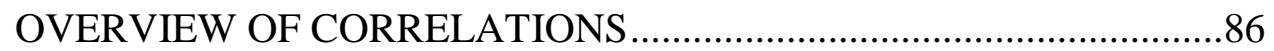

DIRECT RELATIONSHIP WITH PROFESSIONALISM........................87

INVERSE RELATIONSHIP WITH PROFESSIONALSIM .....................88

SUMMARY FOR RESEARCH QUESTIONS THREE ...........................89

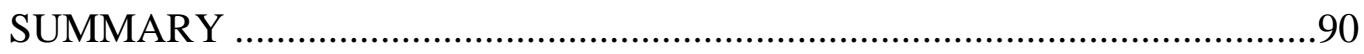

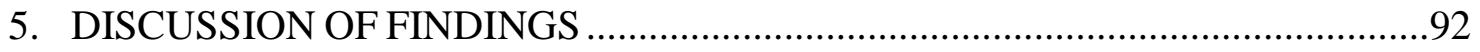

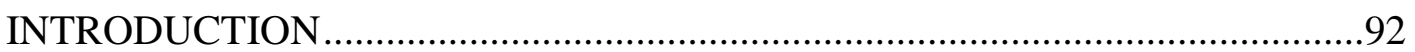

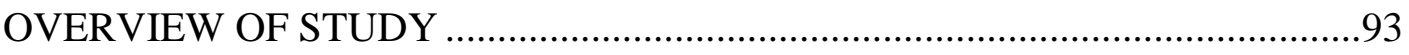

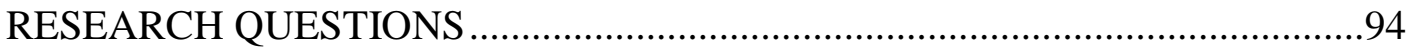

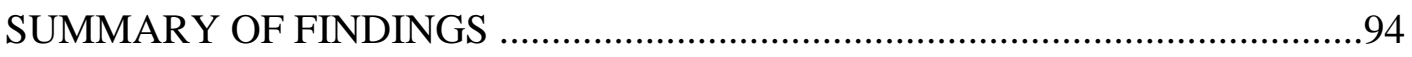

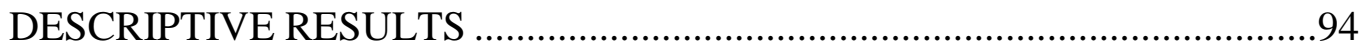

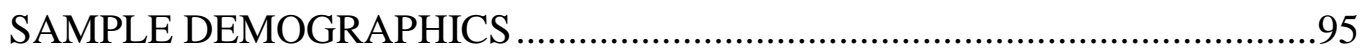

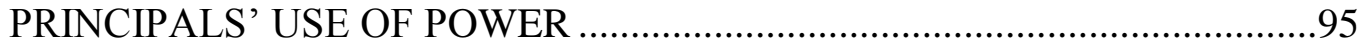

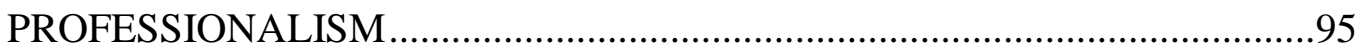

RESEARCH QUESTION ONE .....................................................................

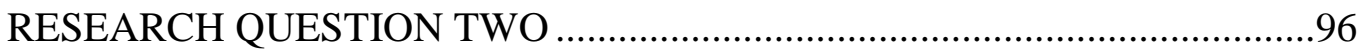

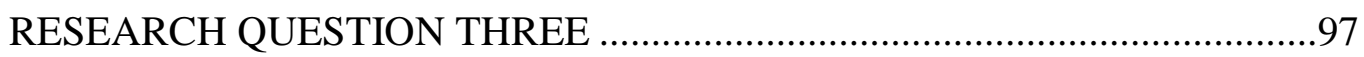

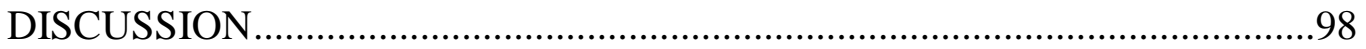

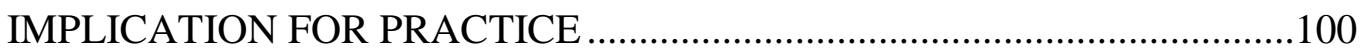

RECOMMENDATION FOR FUTURE RESEARCH ..........................................102 


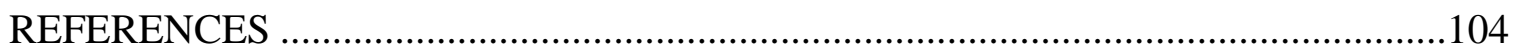

APPENDIX

A. POWER AND PROFESSIONALISM INVENTORY .........................................109

B. TEACHER PROFESSIOINALISM INVENTORY - SELF ..................................110

C. POWER PERCEPTION PROFILE-PERCEPTION OF OTHER …………….......113

D. INTRODUCTORY LETTER TO PRINCIPAL ................................................115

E. INTRODUCTORY LETTER/INFORMED CONSENT TO TEACHER.............116

F. INFORMED CONSENT TO PRINCIPAL ....................................................117

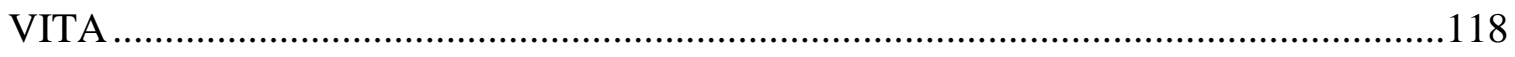




\section{LIST OF TABLES}

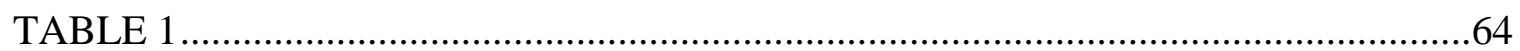

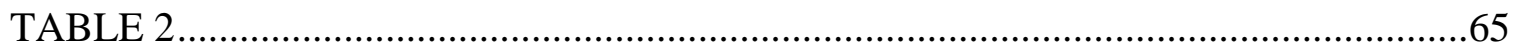

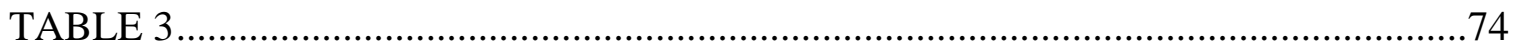

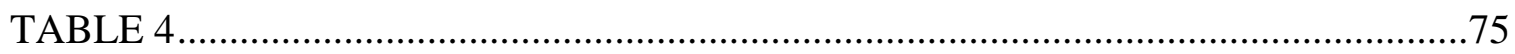

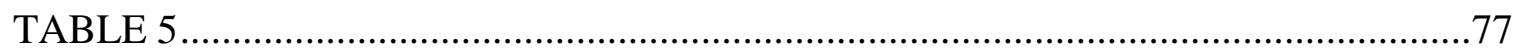

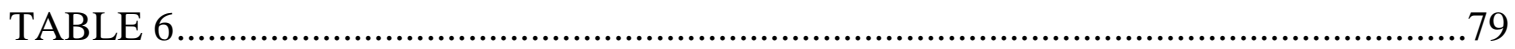

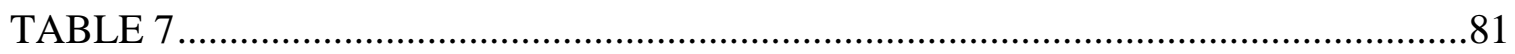

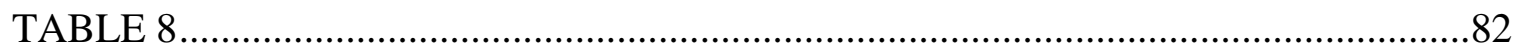

TABLE 9

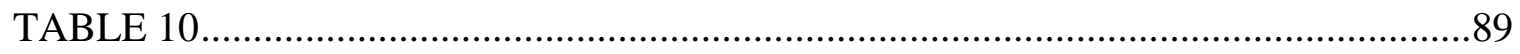




\section{LIST OF FIGURES}

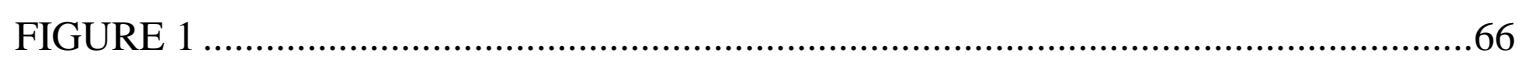

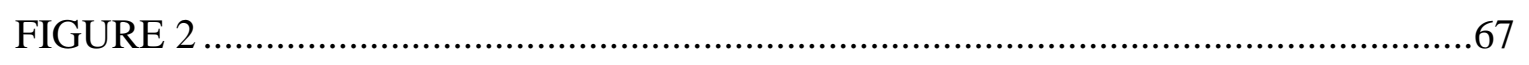

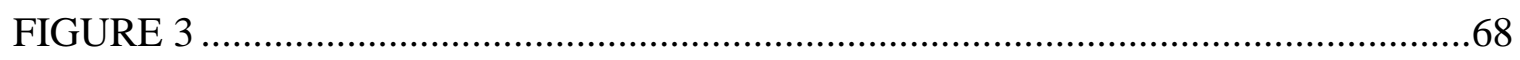

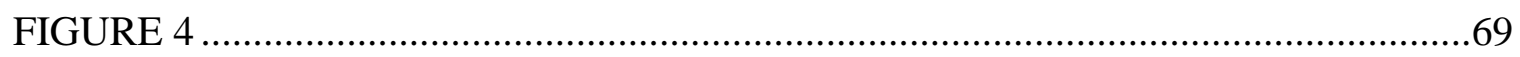

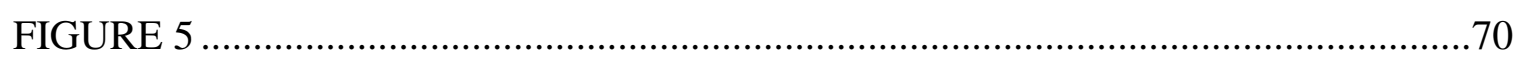

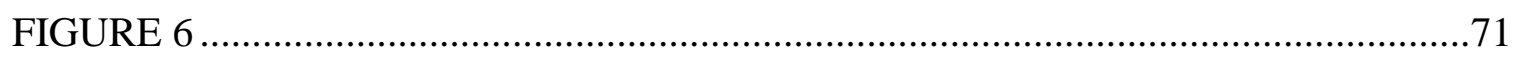

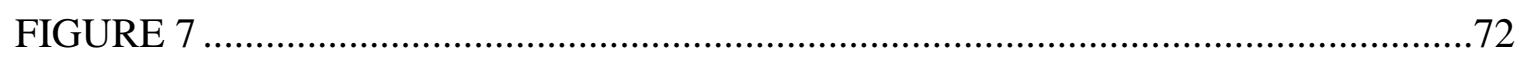

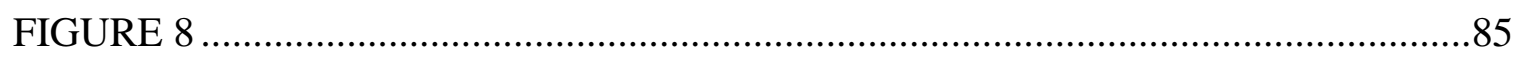


THE RELATIONSHIP BETWEEN

THE PRINCIPAL'S USE OF POWER AND

THE TEACHERS' SELF-PERCEPTION OF PROFESSIONALISM

\author{
Travis W. Graham \\ Dr. Cynthia MacGregor, Dissertation Supervisor
}

\begin{abstract}
The purpose of this study was to examine the relationship between the high school principals' use of power and teacher's self-perception of professionalism. Seven bases of power were explored during this study: (a) reward power, (b) coercive power, (c) legitimate power, (d) referent power, (e) expert power, (f) information power, and (g) connection power. Four dimensions of professionalism were identified as subscales and were: (a) personal characteristics, (b) commitment to change and continuous improvement, (c) subject and pedagogical knowledge, and (d) activities beyond the classroom.
\end{abstract}

The quantitative study combined two data collection tools, the Power Perception Profile-Perception of Other and the Teacher Professionalism Inventory-Self, to provide opportunity for teachers to describe their current perceptions of their principals' use of power and their self-perception of professionalism. While no relationships were identified as being statistically significant, findings did suggest that teachers' selfperception of professionalism was both directly and inversely related to the principals' use of power. Principals who understand how their use of power grows or hinders their 
teacher's sense of professionalism equips them with the necessary tools to foster professional development that is both positive and beneficial to the teachers. 


\section{CHAPTER ONE \\ INTRODUCTION TO THE STUDY}

\section{Background}

Since the dawn of the human resource movement, the relationship between superior and subordinate has been closely examined. Hundreds of studies ranging from human relations (Agarwala, 2002; Sun, Aryee, \& Law, 2007), leadership theory, and organizational management, have added greatly to the body of knowledge in the arena of educational leadership and administration (Cramer, 1996). Organizational theories and leadership theories have provided both qualitative and quantitative data pertaining to the effects and outcomes leadership practices have on both the educational institution as an organization and the teachers, as individuals, professionally.

The human resource movement found its footing in the contributions of Frederick Winslow Taylor's (1916) scientific management model and reached its pinnacle with Elton Mayo's (1933) work when he conducted a multiyear study at the Hawthorn plant of the Western Electric Company beginning in 1927. Through such work the understanding of how humans interacted with, and were impacted by, organizations became more prevalent. With the knowledge gained of how humans best work, the belief that the worker lived to serve the purposes of the organization and meet its needs quickly dwindled, beginning the establishment of the human resource theory.

Through the understanding gained from Taylor (1916) and Mayo (1933) the human component existent in the educational arena became more prevalent. No longer were schools operating using the mass production model of the factory. Rather, 
educational leaders began to understand that when teachers gained satisfaction from what they did, they worked harder. This understanding began to impact the means by which school leaders influenced their teachers, ultimately impacting the student body.

Douglas Murray McGregor (1960), one of the leaders of the human resource movement, considered the contrasting means of management and introduced his Theory $\mathrm{X}$ and Theory $\mathrm{Y}$. Theory $\mathrm{X}$ represented the worker who was lazy and unmotivated, demanding that management coerce or bribe production, and Theory Y described the worker desired to do well and was self-motivated.

Psychologically, the individual who operates under the tenants of the Theory $\mathrm{X}$ manager receives no motivation and has no desire to go above and beyond-his or her needs are not being met. However, the Theory $\mathrm{Y}$ worker is self-motivated and understands that his/her organization is an advocate for his/her development professionally. The Theory Y manager provides opportunity for the worker to explore ideas and share findings with the team (McGregor, 1960). Within the human resource theory a symbiotic relationship between human and organization was developed with an emphasis placed on mutual benefices gained when human psychological needs are met.

The human resource frame, as articulated by Bolman and Deal (2008), provides a lens for leaders in the educational arena to gain understanding concerning how the human components impacts the organization. Imbedded within this frame are four major tenants (a) organizations exist to serve and meet the needs of people, (b) people and organization are interdependent, (c) if fit between individual and organization is poor both suffer, and (d) a good fit benefits both (Bolman \& Deal, 2008). The first tenant, that organizations exist to serve and meet the needs of people, is often only partially fulfilled 
by educational leaders. While the educational arena exists to serve and meet the needs of students, it also exists to serve and meet the needs of the teachers.

Principals can, at times, impose programs, committees, curricular implementations, and agendas on teachers, disregarding how such things will impact the teachers. Teachers are informed by principals that such impositions are what is best for the students and so teachers are expected to implement changes with rigor. The principals' means of communicating and enforcing such implementations can often times impact how teachers employ the requests. Furthermore, the means by which school leaders communicate and influence teachers to do tasks can affect the teacher's job satisfaction and self-perception of professionalism.

\section{Statement of the Problem}

Probably the most influential agent of the educational arena is the classroom teacher (DuFour \& Eaker, 1998; McMahon, 2007). While this may be true, it is only recently that an emphasis has been placed on the teacher as a professional. The face of education in Missouri is changing, and principals, school leaders, and teachers are faced with the daunting task of "preparing every child for success in school and in life" (DESE, 2013, p. 1). With such an emphasis placed on the performance of the student, the teacher's development as a professional has often been overlooked. Principals provide professional development for the teachers centralized around meeting the needs of the students, but what do principals do to meet the professional needs of the teacher?

While teachers may be the most influential agent within the educational arena, that influence predominately reaches to the student. Principals and school leaders, however, significantly impact teachers and how they relate to the profession, not merely 
how they relate to the students. Goodson and Hargreaves (1996) noted that, "what teachers think about professionalism or what they experience under its name are addressed too rarely" (p. vii). Research is limited both in addressing how teachers perceive themselves as professionals and examining how the principal impacts such an awareness through their use of power. Principals and school leaders need to be aware of the significant impact they have on teachers and how teachers view themselves as professionals. Principals who possess an awareness of how they impact their teachers' sense of professionalism and operationalize that awareness are school leaders who empower their teachers to be active leaders within their educational organization. Furthermore, the school leader provides opportunity for the teaching professional to contribute productively to not only the educational encounters of students, but their own professional development.

\section{Purpose of the Study}

The purpose of this study was to examine the relationship between principals' use of power and teacher's self-perception of professionalism. Seven bases of power were explored for the purpose of this study. Five bases adapted from French and Raven (1959), include; (a) Reward Power, (b) Coercive Power, (c) Legitimate Power, (d) Referent Power, and (e) Expert Power. Raven and Kruglanski (1975) introduced (f) Information Power, and (g) Connection Power was incorporated by Hersey, Blanchard, and Natemeyer (1979). For the purpose of this study the examination of the teachers' self-perception of professionalism encompassed four dimensions of professionalism: (a) Personal Characteristics, (b) Commitment to Change and Continuous Improvement, (c) Subject and Pedagogical Knowledge, (d) participation in educational activities Beyond 
the Classroom (Tichenor \& Tichenor, 2009; Sockett, 1993). By examining the relationship existent between the principal's use of power and teachers' self-perception of professionalism, it was the intention of this researcher to provide data that would inform educational leaders of how to support professionalism within the organization as an entity and the field of education as a whole.

\section{Research Questions}

1. As perceived by teachers, how do secondary principals use power?

2. How do secondary teachers view themselves as professionals?

3. What is the relationships between the teachers' perception of the principal's use of power and their self-perceptions of professionalism?

a. What base of power used by principals is directly related to teachers' selfperception of professionalism?

b. What base of power used by principals is inversely related to teachers' self-perception of professionalism?

\section{Conceptual Underpinnings}

Understanding power and how one utilizes it within the context of educational leadership can provide insight when exploring the relationship between the principal's use of power and teachers' self-perception of professionalism. For the purpose of this framework the basis of power was described as the influence a social agent has on a person (French \& Raven, 2011/1959). For the purpose of this study seven bases of power were selected. Five common and important bases of power, included: (a) Reward Power, (b) Coercive Power, (c) Legitimate Power, (d) Referent Power, and (e) Expert Power (French \& Raven, 2011/1959). The addition of (f) Information Power (Raven \& 
Kruglanski, 1975) and, (g) Connection Power (Hersey, Blanchard, \& Natemeyer, 1979) were utilized to provide a greater exploration of power. Reward Power is the ability one has to provide rewards. Coercive Power involved one's ability to manipulate. Legitimate Power, though ambiguous, stemmed from internalized powers and one's right to influence with the subordinate obligated to submit. Referent Power focused primarily on a subject's relationship when he/she identified with the superior and submits willingly. Expert Power was exerted when an individual contained knowledge or was perceived to contain knowledge. Information Power pertained to the access to and the use of information. Finally, Connection Power "was based on connections with influential or important people. A leader high in connection power induced compliance from others because they tried to gain favor or avoided disfavor of the powerful connection" (Hersey et al, 1979, p. 419).

Teachers' self-perception of professionalism was framed utilizing the work of Tichenor and Tichenor (2005), Cheng (1996) and Sockett (1993). Professionalism was categorized as encompassing four dimensions: (a) Personal Characteristics, (b) Commitment to Change and Continuous Improvement, (c) Subject and Pedagogical Knowledge, and (d) participation in educational activities Beyond the Classroom. In a study conducted by Tichenor and Tichenor of Stetson University (2005), "professionalism was exhibited in many ways and encompasses both attitudes and behaviors" (p. 92). The study articulated that professionalism went beyond the classroom for teachers, encompassing characteristics such as effective communication with parents, colleagues, and community members; exemplary role models, participated in school decisions, cooperative, concerned about fellow teachers, and participated in professional 
organizations (p. 94). The driving question for this researcher thus becomes, "were such characteristics effected by the educational leader's use of power?"

\section{Design and Methods}

This research study was quantitative in design. It examined the relationship between the independent variable, the principal's use of power, and the dependent variable, the teacher's self-perception of professionalism (Creswell, 2009). The sample group of approximately 1,280 certified secondary classroom teachers' were selected utilizing a convenience means of sampling (Fink, 2009). The sample was drawn from a population size of approximately 20,020 certified secondary classroom teachers within the state of Missouri.

Once the sample group was selected the researcher provided the respective school principals a letter that outlined the purpose of the study and requested permission to conduct research. After approval was granted to gather data to address the research questions presented in this study, the researcher utilized an online survey that was disseminated to the teachers in the sample group through the high school principals.

The online survey tool created for the purpose of this study was entitled Power and Professionalism and combined two inventories to address the research questions developed for the purpose of this study. The Teacher Professionalism Inventory - Self (Appendix B) was adapted from the work of Tichenor and Tichenor (2005), Cheng (1996) and Sockett (1993) and was utilized to address how teachers' self-perceived professionalism. Furthermore, the Power Perception Profile-Perception of Other (Appendix C) as developed by Hersey, Blanchard, and Natemeyer (1988) were utilized to gather data pertaining to the teacher's perception of the principal's use of power. 


\section{Assumptions}

Following is an articulation of the assumptions that pertained to this study. It was assumed that teachers considered themselves as professionals, therefore taking time to answer the research questions truthfully and thoughtfully, reflecting on how they perceived themselves as a professional. Furthermore, it was assumed that teachers, as professionals, operate within the tenants of the in-group as articulated by the LeaderMember Exchange theory, and Theory Y of McGregor's (1960) Theory X and Theory Y model.

This study included a sample from a population of approximately 20,020 high school classroom teachers within the state of Missouri. It was assumed that, since the building administrator disseminated the online survey tool to all classroom teachers within the high school building, only certified classroom teachers received the invitation to participate in the study. Finally, it was assumed that secondary school principals hold to the belief that teachers are professionals and aspire to treat them as such through the provision of professional development opportunities that personally impact the teacher as a growing educator.

\section{Definition of Key Terms}

The following definitions were compiled as a result of examining related literature relevant to this study. The terms provided below helped to establish understanding as it pertained to this study. Furthermore the definitions helped to articulate key concepts pertaining to this study. 


\section{Leader-Member Exchange Theory}

Leader-member exchange (LMX) theory takes into consideration, and examines the relationship existent between the leader and the subordinate. Through the examination of a dyadic relationship, LMX articulates that leadership is not something a leader does to a subordinate, rather it is an interactive relationship that involves both the leader and the subordinate (Northouse, 2010).

In-Group. The in-group is a function of the LMX theory that describes one of the two general types of relationships. Those considered part of the in-group "were based on expanded and negotiated role responsibilities" (Northouse, 2010, p. 149). Being a part of the in-group indicated that the leader and the subordinate worked well with each other.

Out-Group. The out-group is a function of the LMX theory that describes the second of two types of relationships. Those considered part of the out-group are considered such because they complete tasks as prescribed and generally refrain from going above and beyond (Northouse, 2010).

\section{Power}

The purpose of this study the existence of power will be defined as authority gained through position or title. Seven bases of power will be examined.

Coercive Power. Coercive power is operationalized through fear. "A leader high in coercive power is seen as inducing compliance because failure to comply will lead to punishment, such as undesirable work assignments, reprimands, or dismissal" (Hersey, Blanchard, \& Natemeyer, 1979, p. 419). 
Expert Power. A leader high in expert power is someone who is perceived as an individual in possession of the knowledge, skills, and expertise to facilitate work (Hersey, Blanchard, \& Natemeyer, 1979).

Legitimate Power. A leader possessing legitimate power is given such because of the position they hold within an organization. The higher the position, the higher the amount of legitimate power is given (Hersey, Blanchard, \& Natemeyer, 1979).

Referent Power. A leader possessing referent power often times will have subordinates that emulate his or her behaviors. The more the leader is liked and revered, the more the subordinates want to be like him or her (Hersey, Blanchard, \& Natemeyer, 1979).

Reward Power. Based on the leader's ability and willingness to provide rewards to subordinates for accomplishing tasks. Reward power can be used to influence compliance (Hersey, Blanchard, \& Natemeyer, 1979).

Informational Power. Based on the leader's possession and distribution of information. Leaders may use this power base to withhold information from or provide information to subordinates as needed in order to ensure compliance (Hersey, Blanchard, \& Natemeyer, 1979).

Connection Power. "Based on connections with influential or important people. A leader high in connection power induces compliance from others because they try to gain favor or avoid disfavor of the powerful connection" (Hersey, Blanchard, \& Natemeyer, 1979, p. 419). 


\section{Teacher Professionalism}

Teacher professionalism is defined as the presence of characteristics and traits considered imperative for the success of the teacher within the field of education. Specifically, teacher professionalism encapsulates the attitude, actions, beliefs, and behavior or the teacher. For the purpose of this study four dimensions of teacher professionalism are addressed (Tichenor \& Tichenor, 2005; Cheng, 1996, and Sockett, 1993).

Personal Characteristics. The professional teacher is one who is, "resilient and keeps his/her composure at all times and under all circumstances; is caring, nurturing, friendly, patient with all, well-organized, flexible, displays confidence in the classroom; and remembers that he/she is a role model for students" (Tichenor \& Tichenor, 2004, p. 92).

Commitment to Change/Continuous Improvement. The professional teacher goes above and beyond and has a dedication to continuous improvement. He or she accepts and welcomes feedback and constructive criticism if it results in positive change; reflective and constantly self-assessing his/her methods; not satisfied with the status quo, attends workshops and conferences so as to improve his/her practice (Tichenor \& Tichenor, 2004).

Subject and Pedagogical Knowledge. The teaching professional possesses both subject knowledge and pedagogical knowledge. The teacher endeavors to increase his/her knowledge of her subject by attending conferences and collaborating with peers. The professional teacher increases pedagogical knowledge by observing peers in the classroom, collaborating with fellow teachers and discussing best instructional practices; 
applies learning theories, addresses needs of students, uses appropriate learning strategies (Tichenor \& Tichenor, 2004).

Beyond the Classroom. The teaching professional recognizes that, "they have a responsibility to collaborate and cooperate with faculty, staff, administration, parents, and community members" (Tichenor \& Tichenor, 2004, p. 93). Such professionals are; involved in developing and changing policies as needed; engaged in service projects impacting his/her community; establishing relationships with families and community members beyond the classroom.

\section{Professionalization}

Professionalization is defined for the purposes of this research as the process by which a field establishes professional status. The professionalization of a field involves two components, structural and attitudinal. The structural component addresses four areas: (a) the creation of a full time occupation, (b) the establishment of a training school, (c) the formation of professional associations, and (d) the formation of a code of ethics. The attitudinal component addresses five areas: (a) the use of professional organizations and major references, (b) a belief in service to the public, (c) belief in self-regulation, (d) a sense of calling to the field, and (e) autonomy. Combined together, the structural and the attitudinal, a professional works through the professionalization process (Hall, 1968, p. 92-93).

\section{Significance of the Study}

Gaining an understanding of the relationship between the principals' use of power and teachers' self-perception of professionalism better enabled both educational leaders and teachers as professionals to support both organizational and professional goals. When 
principals understood how their use of power related to the teachers' self-perception of professionalism they became an essential support for developing, encouraging, and challenging teachers to become their best.

The face of education is changing. Teachers' roles and responsibilities for being facilitators for the acquisition of knowledge rather than disseminators of knowledge has become more prevalent. With the incorporation of the Common Core State Standards (CCSS) and the fifth cycle of the Missouri School Improvement Plan (MSIP 5) teachers are tasked with greater responsibilities to prepare all students for life. The teacher as a professional "exhibits professionalism in the following: personal characteristics, commitment to change and continuous improvement, stays abreast of subject and pedagogical knowledge, and serves as a positive role model beyond the classroom" (Tichenor \& Tichenor, 2009). Principals who advocate for teachers who exhibit the previously mentioned characteristics as well as understand the role in supporting teacher development sets the stage for establishing a culture that values teacher professionalism.

\section{Summary}

While professionalism in the field of education is not new, the advocacy for teachers to be viewed as such is becoming more and more prevalent. The human resource theory has contributed to such a movement because it changed organizational management by accounting for the feelings and thoughts of the people involved in the organization. The purpose of the organization evolved from being an entity that exploited the abilities of members, to meeting individual needs and vice versa, working in a symbiotic relationship. The human resource frame (Bolman \& Deal, 2008) provided for educational leaders a lens to gain understanding of how their leadership can impact the 
human aspect of an organization. Douglas McGregor's (1960) Theory X and Theory Y took into account the perspective of management and the motivation of workers and the impact that job satisfaction had on the human component. Finally, the understanding of how the principal's use of power related to teacher's self-perception of professionalism better equipped educational leaders and teachers to meet both organizational and professional goals.

Chapter One included an explanation of the conceptual underpinnings that were used to frame this study, the design and methodology utilized to carry out the study. Power was defined utilizing the work of French and Raven, (2011/1959); and Hersey, Blanchard, and Natemeyer (1979). The qualities of professionalism were established by the work of Hall (Snizek, 1972), Sockett, (1993), Tichenor and Tichenor (2005, 2009), and Robinson (2008).

Chapter Two provides a comprehensive literature review. It includes a synthesis of literature centralized around two major themes: professionalism and power. Professionalism is explored through examining literature on the professionalization of teaching, professional development and the impact on teachers as professionals and concludes with an examination of literature that explores the deprofessionalization of teachers. Power is explored through examining seven bases of power, the exercise of power, the relationship that exists between the leader and the subordinate through the Leader-Member Exchange Theory and Theory X - Theory Y and concludes with the principal use of power. Chapter Three articulates the research methodology and design of the study. Quantitative findings and analysis are presented in Chapter Four. Finally, Chapter Five outlines the findings and suggestions for future research. 


\section{CHAPTER TWO}

\section{LITERATURE REVIEW}

\section{Introduction}

Since the publication of $A$ Nation at Risk (1983), public education as a whole received great criticism. On August 26, 1981 Secretary of Education T.H. Bell established the National Commission on Excellence in Education (NCEE) to address the overall quality of education in the United States. The commission worked to address "the widespread public perception that something is seriously remiss in our educational system" (National Commission on Excellence in Education, 1983, p. 6). While the commission, comprised of members of varying backgrounds from the educational arena, was charged with many tasks, one of particular interest was, "assessing the quality of teaching and learning in our Nation's public and private schools, colleges, and universities" (NCEE, 1983, p. 6).

The Nation at Risk report examined the status of the education in the United States as it compared to the global society. The findings of the commission were that:

Our Nation is at risk. Our once unchallenged preeminence in commerce, industry, science, and technological innovation is being overtaken by competitors throughout the world. This report is concerned with only one of the many causes and dimensions of the problem, but it is the one that undergirds American prosperity, security, and civility. We report to the American people that while we can take justifiable pride in what our schools and colleges have historically accomplished and contributed to the United States and the well-being of its 
people, the educational foundations of our society are presently being eroded by a rising tide of mediocrity that threatens our very future as a Nation and a people. What was unimaginable a generation ago has begun to occur-others are matching and surpassing our educational attainment. (NCEE, 1983, p. 8) Gleaning from papers written by experts on a variety of educational issues, administrators, teachers, board of education members, public officials, and the analysis of problems in education that were existent at the time, the commission endeavored to inform the public of the present state of education. The commission concluded that if the United States were to be competitive in an ever-changing global society, educational reform must happen.

In a world of ever-accelerating competition and change in the conditions of the workplace, of ever-greater danger, and of ever-larger opportunities for those prepared to meet them, educational reform should focus on the goal of creating a Learning Society. At the heart of such a society is the commitment to a set of values and to a system of education that affords all members the opportunity to stretch their minds to full capacity, from early childhood through adulthood, learning more as the world itself changes. (NCEE, 1983, p. 13)

One of the major highlights of the report regarding teachers was that, "the Commission found that not enough of the academically able students were being attracted to teaching; that teacher preparation programs need substantial improvement; that the professional working life of teachers is on the whole unacceptable; and that serious shortage of teachers exists in the field" (NCEE, 1983, p. 19). Furthermore, the Commission found that too many of the teachers entering into the profession were being 
drawn from the bottom quarter of those graduating high school and college (NCEE, 1983, p. 19). In addition, institutions training teachers allotted more credit focused on education courses resulting in less time refining and strengthening the knowledge base of the individual teacher within their subject area of interest.

Since the publication of the report the role of education and means of disseminating concepts and materials to students changed dramatically. "Employees are moving from needing repetitive skills to knowing how to deal with surprises and exceptions, from depending on memory and facts to being spontaneous and creative, from avoiding risk to taking risk, from focusing on policies and procedures to building collaboration with people" (Marquardt, 2011, p. 13).

Proceeding the publication of A Nation at Risk educational reform placed an emphasis on empowering stakeholders and endeavoring to create learning organizations where not only the performance of students was enhanced, but teachers and administrators as well. In the 44th annual Phi Delta Kappa/Gallup Poll of the Public's Attitudes Toward the Public Schools, Bushaw and Lopez (2012) wrote, "we agree that teachers should be rigorously screened and prepared, at least to the level of other professions such as engineering, business, law, and medicine" (p. 9).

Resulting from the report, "forty-one states drafted significant plans to reform, as opposed to five that had begun implementing reforms at a statewide level prior to $A$ Nation at Risk" (McMahon, 2007, p. 4). The reform of education ushered in an examination of school leadership and the professionalization of teachers. "Many scholars have voiced their intention to develop professionalism and facilitate teacher performance by improving the workplace and organizational environment in schools. Among the 
many organizational factors in school, principal's leadership, school organizational structure, and teachers' social norms seem to be important for affecting school functioning and teacher performance" (Cheng, 1996, p. 164).

The purpose of this review was to inform the reader of the relationship between the principal's use of power and the teacher's self-perception of professionalism. This chapter explored both the concept of professionalism, and power as used by the principal. Furthermore, this chapter examined the relationship between the principal and the teacher using the Leader-Member Exchange Theory (Northouse, 2010) and Theory X and Theory Y (McGregor, 1960) to examine the interaction between the two, the principal and the teacher. Finally, this chapter endeavored to inform how the two, professionalism and power, related to the teacher's self-perception of professionalism.

\section{Professionalism}

Professionalism is a term that encompassed the behaviors and beliefs of the professional. Difficult to define, professionalism had for many years been ambiguous and difficult to articulate as "it was a constantly changing and evolving concept, forced to transform as the world changes and the work available within our world changes" (Bell, 2011, p. 14). Webster (1997) defined professionalism as, "professional character, spirit, or methods; the standing, practice, or methods of a professional, as distinguished from those of an amateur" (p. 631). Sahu (2008) expounded further, defining professionalism as, "the behavior, skill, qualities special conventions, forms of politeness, etc. associated with a certain profession or shown by a professional" (p. 1). Socket (1993) described professionalism as the "quality of practice," and said: 
It [professionalism] describes the manner of conduct within an occupation, how members integrate their obligations with their knowledge and skill in a context of collegiality and of contractual and ethical relations with clients. Every action within the role is to be judged by standards specific to the profession. The collection of those constantly changing standards is the corpus of understandings, values, insights, and knowledge we call our professionalism. (p. 9)

Bell (2011) provided a comprehensive overview of literature encompassing the work of Goodson and Hargreaves (1996) which described five major views of professionalism: (a) classical professionalism, (b) practical professionalism, (c) flexible professionalism, (d) extended professionalism, and (e) complex professionalism. The classical view was characterized by the professional who possessed a special knowledgebase, holds others in high regard, is self-regulated concerning training, possessed an intrinsic drive to improve, and is ethical. "Teaching falls short of being a profession in this regard due to the vague nature of the body of knowledge one needs to teach. The knowledge and skills needed to teach are not easily encapsulated, such as those in law and medicine" (Bell, 2011, p. 15).

Practical professionalism as outlined by Bell (2011), described professionals who were characterized by their "practical knowledge and judgment skills they hold about their work" (p. 15). The argument was posed that teachers, though in possession of practical knowledge, do not necessarily possess knowledge that is practical to and relevant to their field. Goodson and Hargreaves (1996) moved that not all of the practical knowledge possessed by teachers is of educational value. Thus, teachers are not considered to be among those who are categorized as practical professionals. The 
remaining three: (a) flexible professionalism, (b) extended professionalism, and (c) complex professionalism, "place value on both theoretical and practical professional development, and collaboration among colleagues. These types of professionalism seem to be that which is emerging as governments exert higher control of education systems, but the fear is that the result will be teacher exploitation and burnout" (Bell, 2011, p. 16).

Goodson and Hargreaves (1996) articulated a sixth view of professionalism, postmodern professionalism or interactive professionalism which encompassed seven principles: (a) discretionary judgment, (b) moral and social purposes of teaching, (c) engaging in a collaborative culture as a way to enhance expertise and solve problems of professional practice, (d) balance work of both the heteronomy and autonomy, (e) proactive in caring for students with a genuine interest, (f) dedication and drive towards continuous learning, and (g) levels of status and reward appropriate for varying levels of task complexity and completion (pp. $20-21$ ). Since definitions of professionalism are malleable to the field in which they are applied, the postmodern professional appeared applicable to the teacher and began to establish the foundation for teachers as professionals.

Evans (2008) distinguished between the concept of professionalism and the existence of a professional culture. She emphasized how professional culture accounted for the attitudinal behaviors of an individual, encompassed beliefs, practices, relationships, language and symbols that were used to reflect the members of such a profession. Furthermore, she deciphers between professional culture and professionalism by stating that, "professionalism is the consensus of 'norms' which may apply to being 
and behaving as a professional defining how they function personally, organizationally, and in broader political conditions" (p. 25).

Building on her study of professionalism Evans (2008) examined the work of Hoyle (1975) who, “identified two distinct aspects of teachers' professional lives: professionalism and professionality." In 1975 Hoyle explained the distinction as being status-related elements of teachers' work, which he categorized as professionalism, and those elements of the job that constitute knowledge, skills, and procedures that teachers use in their work, and which he categorized as professionality" (Evans, 2008, p. 25-26). Similar to the work of Hall (1968) and Hoyle (1975), she stated that, "to be real, professionalism has to be something that people - professionals - actually 'do', not simply something that the government or any other agency wants them to do, or mistakenly imagines they are doing” (Evans, 2008, 27).

In an effort to establish teaching as a profession over the course of the past two decades, numerous initiatives were implemented to augment professionalism in education. "Over the years, reformers, policy makers, and educators have taken aim at different parts of the education profession in various attempts to enhance teacher's practice, increase student learning, and strengthen the overall profession" (Glazer, 2008, p. 169). With such an emphasis placed on enhancing teacher practice, student achievement, and the strengthening of the overall profession, awareness of professionalism in education began to prosper. "In the 1990's, some reformers and researchers targeted the organization of schools with the hope that enhanced collegial interaction among teachers, regular observation of teaching, and better instructional 
leadership would result in a stronger professional orientation and a higher quality of practice" (Glazer, 2008, p. 169).

Expanding the research on professionalism, Tichenor and Tichenor (2005) further explored teaching as a profession and endeavored to gain an understanding of teacher's perspectives on professionalism through comparing education with other professional fields such as sports, music, business, and medicine. In sports, athletes are defined as professionals according to their level of skill and ability in comparison to amateurs. In music, professionals who reach a certain skill level became qualified to receive financial compensation for their performance, much like an athlete. The world of business, success, as marked by fiscal gains, was often times the measure of the professional. Those in health care fields had a set of clearly defined roles, responsibilities, and expectations placed on their behaviors. "Moreover, professionals in the "classic" fields, of law, medicine, and theology have codified rules and expectations for behavior developed over many centuries" (Tichenor \& Tichenor, 2005, p. 89).

Furthermore, Tichenor and Tichenor (2005) contented that professionals were individuals that operated in a profession that demanded a specific skill set, ability level, adherence to a code of expectations; professionalism was the degree to which the professional maintained, adheres to, and operated within the expectations of his/her profession. "In the field of education, however, being a classroom teacher is not always associated with being a professional. That is, American society does not generally view teachers in the same way as they view other professionals; the belief that 'anyone can teach' is not found in other professions (i.e., not just anyone can play professional baseball, or be an accountant or engineer, or practice law or medicine)" (Tichenor \& 
Tichenor, 2005, p. 89). While the position of teaching as a profession may not be viewed in the same light as other professions as described above, the importance of effective teaching and the impact the field has on society as a whole is of great significance (Tichenor \& Tichenor, 2005).

\section{Professionalization}

Described as the quality of practice, professionalism placed an emphasis on the professional's ability to meet certain standards, to abide by a code of conduct, to be skillful and knowledgeable in the areas pertaining to his/her field. The distinction drawn between professionalism and professionalization is that "professionalization is the process whereby an occupation (rather than an individual) gains the status of a profession. When we professionalize teaching we change its status; but a teacher's professionalism is apparent in his or her practice" (Socket, 1993, p. 9).

Hall (1968) formulated that professionalization consisted of both structural and attitudinal components. The structural component address: (a) the creation of a full time occupation, (b) the establishment of a training school, (c) the formation of professional associations, and (d) the formation of a code of ethics. The attitudinal component addresses and additional five components: (a) use of professional organizations and major references, (b) belief in service to the public, (c) belief in self-regulation, (d) a sense of calling to the field, and (e) autonomy (p. 92-93). He believed that both the structural and attitudinal components served as the basis for the professional model. 'It is generally assumed that both aspects are present to a great degree in highly professionalized occupations, while they are present to lesser degrees in the less professionalized occupations" (Hall, 1968, p. 93). 
The professionalization of teaching emphasized whether or not the community values teachers - how much they are paid, fringe benefits, do they have secretarial support, and does the profession govern itself. Such components are highlights of status, not of practice and while they are significant to establishing a profession, they are not essential to establishing professionalism within the profession. With the development of postmodern professionalism, also known as interactive professionalism, Goodson and Hargreaves (1996) articulated seven characteristics that lend themselves towards the process of the professionalization of teaching. While the professionalization of education as a profession was a significant movement, it was not the intention of this researcher to argue for or against education as a profession. However, it was important to have an understanding of the process gone through to establish teaching as a profession in order to effectively examine what factors affect the teachers' self-perception of professionalism.

\section{Professional Development and the Teaching Professional}

Willower (1960) conducted a study entitled Professionalization and Education where he posed the following question, "How does the person who regards himself as a professional relate to those in formal leadership positions in his organization? Does the professional prefer certain leadership styles" (p. 74)? This study stands to be historically significant in regards to the educators' sense of job satisfaction and impact leaders have in fulfilling educators' professional goals.

The hypothesis developed to address Willower's (1960) question, portrayed the teacher professional as an individual who tended to have a positive regard for his or her superior if they "held flexible and indefinite expectations for the subordinates role" (p. 
75). The teaching professional in this regard was an individual who strived to create opportunity where students could achieve at their maximum, when left to their own devices were able to masterfully engage students in the learning process, and utilized creativity to do so. "The types of expectations held by formal leaders are important not only as they relate to the quality of the leader-follower relationship but also because of the way in which they facilitate or hinder the achievement of the goals to which the subordinate professional in the organization aspires" (Willower, 1960, p. 75). His research emphasized the importance of the organizational goals and the professional's goals to coincide as essential to enhancing job satisfaction. While job-satisfaction of teachers as professionals is not the emphasis of this research it is important to note that a teacher's self-perception of their own professionalism is adversely affected if the organizational goals and their personal professional goals do not align.

Hendriks, Luyten, Scheerens, Sleegers, and Steen (2010) conducted an international comparison of the Teaching and Learning International Survey (TALIS), utilizing the results as an analysis of teachers' professional development. The research team stated that, "professional development is viewed here as the body of systematic activities to prepare teaches for their job, including initial training, and continuous professional development within the school setting" (p. 19). The team discovered that much of the data confirmed the held belief that teachers matter.

Teachers' professional development was often geared towards addressing educational quality and is seen as instrumental to student learning and educational achievement. Professional development in this regard placed an emphasis on teacher effectiveness with a focus on the following teacher characteristics: (a) personality, (b) 
subject matter mastery, (c) pedagogical skills, (d) knowledge of pedagogical content, and (e) varied teaching repertoires.

The team's research examined, in depth, professional development activities in relationship to teachers' professional development (Hendricks et al., 2010). Their findings indicated that 'teachers who have greater professional development needs found that professional development had a stronger impact on their work. These findings indicated that teachers' motivation played an important role in the impact of professional development on teachers' practices as perceived by teachers themselves" (p. 195). Research revealed that teachers who were motivated, experienced a higher degree of selfefficacy, a willingness to take risks concerning instruction and pedagogy, and were more willing to accept feedback, as well as contribute productively in decisions affecting their teaching directly.

Educational reforms, much like that of No Child Left Behind Act of 2001 (NCLB), "tried to leverage state control in an effort to cajole and coerce schools into higher levels of performance" (Glaser, 2008, p. 169). With such reforms came prescribed methods of instruction, teacher evaluation protocols, and greater demands of leadership in instruction from the building administrator. Adverse to the concepts of the teacher as a professional were the constructs of the professional development mechanisms that were often put in place within the educational establishment in order to create sense of accountability to achieve such reforms. Such constructs can leave the teaching professional feeling a sense of deprofessionalization (Bell, 2011). Goodson and Hargreaves (1996) stated: 
More broadly, while movements towards site-based management in schools may have involved teachers more in school development planning and collective decision-making, this has often been in context where overall budgets have been reduced ('we give you less; you allocate it'); where many of the major areas of decision-making in terms of curriculum outcomes and testing requirements have been arrogated to the center ('we set the ends: you deliver the means'); and where what schools and teachers are required to manage is downloaded administrivia rather than issues of fundamental purpose and direction ('we control; you manage'). (p. 2)

Evans (2008) addressed the concept of professional development as presently employed in school. She defines professional development as, "the process whereby people's professionality and/or professionalism may be considered to be enhanced" ( $p$. 30). She discussed two elements that comprised the concept of professional development: (a) attitudinal, and (b) functional. The attitudinal element encompassed features such as intellect and motivation. The functional element highlighted procedural practices and production. Evans addressed the issue that present day professional development tends to target and focus on the functional rather than the attitudinal and that, "to be effective, professional development initiatives or policy need to incorporate not only mechanisms for achieving functional development, but also recognition of the great significance of attitudinal development" (Evans, 2008, p. 34).

\section{Deprofessionalization}

Bell (2011) described the concept of deprofressionalization, indicating that it "refers to strategies and institutional changes that decrease one's sense of 
professionalism" (p. 8). Bell's study examined teachers' sense of professionalism and how the teachers' self-perception of professionalism, whether high or low, can adversely impact how the teacher performs and their level of job satisfaction (p. 9). "If teachers believe their professionalism is being threatened, then it is possible they may not be able to produce the best environment for optimum success. Research warns that teachers can start to feel guilty about not being able to complete roles to their satisfaction in an environment of intensification, and describes teacher behavior that is guilt-driven and guilt-ridden as 'unproductive and unprofessional'” (Bell, 2011, p. 9).

Apple (1986), Wong (2006), and Hargreaves (2004) emphasized two major components contributing to the deprofessionalization of teachers: (a) intensification, and (b) deskilling. Intensification characterized the time constraints and workloads placed on teachers, often times accounting for the teachers' feelings of frustration because there simply isn't enough time to meet the demands. Vallie and Buese (2007) discovered that through incorporating differentiated instruction, intensification and expansion of work ensued. "Some tasks, such as instructional planning, became more collaborative as teachers relied on each other to learn how to use highly structured and paced curricula and to align their curriculum coverage to state standards. Other tasks, such as organizational system management, were strongly institutional, stemming directly from a district mandate rather than an intrinsic desire to participate in organizational improvement efforts" (p. 533).

While Vallie and Buese's (2007) work exemplified intensification, it also revealed deskilling and the impact it can have on professionalization. Teachers can often perceive state mandated standards, adoption of structured curriculum, and mandated 
collaboration as a means of deskilling since the teacher professional is required to use his or her skills less as things become prescriptive. Furlong (2005) recalled that:

During the 1970's, the prevailing image of teacher professionalism was of teachers possessing a high degree of autonomy justified by their expertise. It was widely accepted that their role included the freedom to decide not only how to teach but also what to teach and assess pupils on, and that they had a particular responsibility for curriculum development and innovation. (p. 120)

Troman's (1996) examination of what has been termed the rise of the newprofessional, examined the work of Apple (1986) and stated that, "Apple suggests that this crisis in capitalism will produce a new kind of teacher. Apples creates an image of the new type of teacher as a technician who, robbed of traditional craft skills in curriculum and assessment, and experiencing the intensification of work, merely implements the plans which have been designed by others" (Troman, 1996, pp. 473-474). The crisis in capitalism referred to addresses the rising demand for accountability and performance as required by the local state and national government as it effects education and educational practices.

The concept of professionalism has evolved over time and continues to work, providing for educators a platform on which they can position themselves in regards to a societal position. The professionalization of education has been a journey, endeavoring to standardized acceptable characteristics and behaviors for teachers so as to confirm the field as a profession (Evans, 2005; Glaser, 2008; Hall, 1968; and Tichenor \& Tichenor, 2005). 
Professional development significantly impacted the teaching professional by prescribing for teachers specific developmental opportunities that predominately focus on engaging students in successful educational encounters. While student achievement has been established as the measure of a teachers' success, professional development has been focused on enhancing student achievement and providing the teacher tools to do so effectively. While this is not a negative, research indicated that this can sometimes leave the teacher as a professional feeling deprofessionalized.

Teacher professionals who received professional development that were prescriptive and narrative in style experienced aspects of deprofessionalization, such as deskilling and intensification. Principals who led professional development and provided prescriptions to teachers in regards to how they are teaching, methods of instruction, means of instruction, management strategies can often times leave their teachers feeling deskilled. Teachers who were not afforded the opportunity to share in professional development were not required to utilize their expertise or share their insights concerning present practices. This non-participatory style of professional development leaves the teaching professional feeling deskilled, but can allow for intensification to be experienced.

Intensification added stress to the teaching professionals' load that was undue. Requiring them to attend many meetings, meet many deadlines, produce a numerous amount of products, and maintain quality. The school leader who understood when a teacher perceived themselves as a professional began to recognize that teachers performed with greater production and were more satisfied with his or her work. Ideally, 
the principal as the leader played an integral part in developing, promoting, and fostering a culture of professionalism in the educational organization.

\section{Power}

"The concept of power is related to leadership because it is part of the influence

process. Power was the capacity or potential to influence. People had power when they have the ability to affect others' beliefs, attitudes, and courses of action" (Northouse, 2010, p. 7). When power was utilized it is exerted to influence and bring about a desired result. "The phenomena of power and influence involves a dyadic relationship between two agents - a leader and a subordinate" (French \& Raven, 1959/2011). The leader gained a platform of power from the position they held over the subordinate and existent between the two is an influential relationship. Subordinates perceived their leader as someone who had positional power and therefore had the ability to request, direct, command, and impose accordingly.

\section{Bases of Power}

French and Raven (1959/2011) identified five bases of social power that account for the influence and impact the leader has on the subordinate, creating a relationship between the two. "Power bases provide a means for identifying and categorizing the traits abilities, qualities, skills, and characteristics of a person and their position that act as a source of potential influence and power for individuals who are attempting to get something done" (Burnette, 1992, p. 17). When an individual was provided a base of power, he/she was provided a platform on which to direct subordinates to do as he/she requests. "One of the requirements for an individual having the ability to exercise 
power is to occupy a position of power, but the person's actual power rests on how the power is derived from the position implemented" (Biggart \& Hamilton, 1984, p. 543).

The work of French and Raven (1959/2011) provided a strong foundation for understanding social power and how individuals utilize power to influence others to change. The power bases were derived from the relationship between, for the sake of this study, the individual who held the power and the subordinates. For the purpose of this study the power bases was limited to the five identified by French and Raven (1959/2011) with two additional bases of power as identified by Raven and Kruglanski (1975) and Hersey, Blanchard, and Natemeyer (1979). The seven bases of power used for this study were: (a) reward power, (b) coercive power, (c) legitimate power, (d) referent power, (e) expert power (French \& Raven, 1959/2011), with the addition of (f) information power (Raven \& Kruglanski), and (g) connection power (Hersey, Blanchard, \& Natemeyer, 1979).

Reward power was defined as an individuals' ability to reward another individual for doing something. When this power base was used, followers believed that their compliance would result in a reward. The use of reward power can be both formal and informal. The use of rewards through merit pay, overtime compensation, and positive evaluations were all examples of formal uses of reward power. Informal use of reward power could be unofficial time-off, public recognition, and letters of commendation.

The use of the coercive power base involved the use of punishment and/or fear to induce compliance from subordinates. The use of this power base can affect the relationship between leaders and subordinates; subordinates were left feeling forced to do something. "Legitimate power is based on followers viewing the leader as having the 
right to induce compliance" (Burnette, 1992, p. 20). When a leader has legitimate power, they can also be viewed as having positional power, power that was due them simply because of the position they hold within an organization.

The referent power base is derived from the relationship existent between the leader and the follower. "Referent power stems from others viewing the leader as a 'frame of reference' and wishing to be identified with him or her, thus modeling their behavior after the leader" (Burnette, 1992, p. 19). Kennedy (1984/1992), "used the term personal power when describing a source of power equivalent to referent power.

Kennedy also noted that to build a power base, a leader must have alliance power which is based on the numbers of followers emulating the leader" (p. 20).

Expert power was based on the knowledge and expertise as demonstrated by the leader. Followers recognized that the leader possessed the skills and knowledge pertinent complete required tasks competently. Informational power was "based on possession of or access to information that is valuable to others. This power base was influential because others needed or wanted this information" (Hersey, Blanchard, \& Natemeyer, 1979, p. 419). Information was essential to the successful operation of any organization. The leader can either share or withhold from subordinates information in order to achieve intended results. Finally, connection power was rooted in the leader's ability to connect with influential or important people, "A leader high in connection power induces compliance from others because they try to gain favor or avoid disfavor of the powerful connection" (Hersey, Blanchard, \& Natemeyer, 1979, p. 419). 


\section{The Exercise of Power}

"Within the exercise of power there was overlap among the sources of power although each base varies in tis number of dimensions and strategies. When utilizing a specific strategy, a person often relies on more than one base, resulting in an overlap of bases" (Burnette, 1992, p. 25). Though French and Raven (1959/2011) identified five bases of power, the strategies utilized to demonstrate/incorporate power are numerous. Burnette (1992), through a review of literature, identified sixty-five power strategies that were identified to work under the constraints of the five bases of power as identified by French and Raven; namely as follows, (a) reward power strategies, (b) coercive power strategies, (c) legitimate power strategies, (d) referent power strategies, and (e) expert power strategies.

Leaders' use of reward power provided subordinates with rewards according to their efforts and achievements of goals. However, the use of this power strategy was generally most effective when used in combination with another strategy. For instance, if a subordinate was effectively making progress towards a goal and requests more information pertaining to a facet of that goal, the leader may utilize a legitimate power base strategy and provide the subordinate a measure of dispersed information which may be viewed as a reward for their efforts (Burnette, 1992, p. 45).

Burnette's (1992) research indicated that much like the use of reward power strategies, coercive power strategies were generally used in combination with other power bases. Leaders will use punishments in order to coerce subordinates into completing a directive or achieving goal. For instance, if a leader wanted to restrict the follow of information in order to push subordinates to comply, they can. 
"Power strategies derived from the legitimate power base are related to the leader's position. Activating the power from this base involved utilizing the power sources available because of the authority given the leader by higher management" (Burnette, 1992, p. 34). Since leaders had authority given them based on the position they maintain, they also had access to controlling the flow of information and the direction of information. Leaders can utilize their position to control information, ensuring that their directives and requests are acted upon.

The strategies used to execute referent power required the leader to utilize facets of their personality traits. "Putting referent power into action requires socialization and interactions with others" (Burnette, 1992, p. 26). Such interactions were intended to exert influence resulting in subordinates complying with requests or directives made by the leader.

Leaders who applied this strategy engaged subordinates in conversations that left the subordinates feeling confident in the leaders' ability and directives. The use of power-talk "allows an individual to be viewed as powerful, through the use of semantics, sentence structure, pitch, volume, and clarity" (Burnette, 1992, p. 26). Subordinates were more likely to follow individuals who presented themselves in a confident manner and brought assurance. Leaders who exerted referent power often were "precise, concise, rational, logical, and calm" (Burnette, 1992, p. 27). Through the utilization of powertalks, not only did the leader engage the subordinates in referent power base strategies, but also utilized some degree of expert power base strategies. "In order for followers to attach value to a leader's words the communication must reflect the leader's know-how, experience, expertise, confidence, and competence" (Burnette, 1992, p. 28). 
Those who exerted referent power base strategies general were individuals who had strong socialization skills and were noted as being individuals who had charisma and charm (Burnette, 1992). Leaders who connected with people both on a personal and professional plain generally were individuals who convinced subordinates that actions were needed and directives must be completed.

Finally, the utilization of power strategies from the base of expert power, are related to the leader exhibiting behaviors during social interactions that foster an image of competence and expertise. Expert power assists with the implementation of several power strategies arising from other bases - power talk (referent power), information control (legitimate power), outward influence and upward influence (referent power). (Burnette, 1992, p. 43)

The leader became the gatekeeper of information central to the successful operations of the organization. For subordinates to function knowledgeably in their areas, leaders provided them with necessary information to allow informed decisions to be possible. At times, leaders may only provide the necessary information for the subordinate to move forward one step at a time with a dependence on the leader to provide direction and instruction. The organizational leader utilizing connection power will often times use the close ties that he or she developed with powerful stakeholders or influential individuals. Subordinates strive to keep in good graces of such "powerplayers," because of the various opportunities that such individuals may represent (Burnette, 1992).

The power strategies, when operationalized, provided opportunity for the leader to maintain intentional control over subordinates. Whether intentions be pure or have 
alternative motivations, the leader can use such strategies as mentioned to move subordinates in the direction that he or she desires to accomplish specific tasks. Power strategies afforded leaders the practical tools for implementing the bases of power through a means that engaged subordinates into action rather than mere discussion of intentions and tasks to accomplish.

\section{Leader-Member Exchange Theory}

Prior to the development of the Leader-Member Exchange Theory or LMX Theory, "researchers treated leadership as something leaders did toward all of their followers. This assumption implied that leaders treated followers in a collective way, as a group, using an average leadership style" (Northouse, 2010, p. 147). The development of the LMX Theory began to change the assumptions that leaders treated followers collectively and allowed for the relationship between the leader and the follower combined with the interactions existent between the two to become factors in analyzing leadership.

In-Group and Out-Group. Operating within the LMX Theory was the understanding that there exists both an in-group and an out-group.

The relationship between employer and employee changes over time to create and in-group consisting of a small number of trusted followers with whom the leader usually establishes a special, higher-quality exchange relationship and an outgroup with a more formal interaction. The quality of the relationship between employer and employee can have profound influence on many factors of employee performance. (Mauro, 2007, p. 23) 
Early leadership studies focused on effective leaders and leadership styles in an effort to emulate effective leadership and established a protocol for leaders to follow so that successful leadership practices could be replicated. Through such studies it was discovered that there were three dimensions to leadership; the leader domain, the follower domain, and the relationship domain. Prior to this, studies focused on the leader directly, not taking into account the subordinates or the interactions that take place between the leader and the follower. "It was suggested that a leader's characteristics determined the resulting organization through the influence of his or her leadership style. It was premised that if one could study successful leaders and mimic their traits or domain, one could experience the same or very similar positive results that the study leader experienced during their tenure" (Mauro, 2007, p. 23).

The Leader-Member Exchange Theory brought to light the understanding that when a leader mimicked good leadership practices, the audience of subordinates may change, therefore changing the effect the leader may have on the subordinates. LMX accounted for the interactions and exchanges that take place between the leader domain and the follower domain, and expanded on the relationship domain existent between the two. "Past research has suggested that subordinates who are perceived to be competent are likely to build and maintain a higher quality of LMX with their supervisors, while those who are perceived to be incompetent are likely to retain a lower quality of LMX. This is because, based on the notion of reciprocity, supervisors may perceive that competent subordinates will likely reciprocate by performing their work at a higher level" (Chen, Lam, \& Zhong, 2010, p. 598). 
LMX-Theory and Professionalism. When supervisors perceived their subordinates to be competent and able to fulfill their duties and position obligations, the likelihood that the subordinates performed at a greater level of proficiency was increased. Furthermore, when subordinates perceived that their supervisor regarded them as competent and able, the professionalism of the subordinate was believed to be enhanced.

The perception of supervisors regarding the competency of their subordinates is a critical antecedent of high-quality LMX. The perception of the behavior of supervisors (who always hold greater power) by their subordinates should also be considered in explaining the development of LMX. High-quality LMX requires mutual beneficial perceptions and behaviors between the supervisor and the subordinate within a dyad. (Chen, Lam, \& Zhong, 2010, p. 598)

Understanding LMX emphasized the relationship that exists between the leader and the subordinate, principals and teachers as professionals begin to gain an understanding of what components from such a relationship affect the teacher's selfperception of professionalism. The principal's use of power as perceived by the teacher can play a significant role in promoting teacher professionalism in that it directly affects a teacher's perception of competency. While the LMX theory accounts for three domains of leadership: the leader domain, the follower domain, and the relationship domain, Theory X and Theory Y as developed by McGregor (1960) provides a greater perspective concerning the positional views affecting the relationship between the principal and the teacher as a professional. 


\section{Theory X-Y}

Theory X and theory Y as developed by Douglas McGregor (1960) provided perspective concerning the positional views of organizational management and allows for further exploration of the relationship between the principal and the teacher within the educational organization. Theory $\mathrm{X}$ "is based upon the assumption that without the active intervention of management, employees will be passive, avoid work, and resist supporting organizational needs. Thus, according to this view, the task of management is to overcome peoples 'natural' inertia through techniques of persuasion, reward, and punishment so that they direct their efforts toward achieving organizational goals" (Balfour \& Marini, 1991, p. 483).

When examining educational leadership, the principal who led using the tenets of Theory $\mathrm{X}$ as a management platform believed that teachers needed to be persuaded, rewarded, or punished in order to direct efforts towards achieving organizational goals. Principal's leading from this platform believed that they must coerce, in some manner, their teachers to overcome being passive, lazy, and resistant to supporting the organizational goals. McGregor (1960) argued that it was managements' practice, not subordinates behavior that was the root cause of such behavior. Theory X style of management failed to motivate subordinates' because it did not support, encourage, or invest in subordinates. Furthermore, it instilled in subordinates the very behaviors that it sought to overcome (Balfour \& Marini, 1991, p 483).

In contrast, McGregor articulated that people, by nature, are not passive and resistant to organizational needs. Rather, a reciprocal relationship existed. Balfour and Marini (1991) stated that, "the task of theory Y management is to help people recognize 
their potential and achieve their own goals best by directing their own efforts toward organizational objectives" (p. 483). Theory Y perceived that employees were eager to learn and contribute to an organization whose goals and objectives support their own personal and professional desire to excel and contribute productively. When professional goals and organizational goals coincided both the organization and the employee were satisfied.

Theory X/Y and Professionalism. Theory X and Theory Y both impacted how professionalism was supported and enriched in an organization. Russ (2011) synthesized the work of McGregor (1960) by stating:

Theory X managers typically assume employees possess unfavorable opinions about work, are incapable of self-direction, need top-down direction, must be forced to work, and avoid taking responsibility for organizational results.

Conversely, McGregor predicted that managers with a theory Y orientation often assume that employees typically have an instinctual motivation to perform, hold themselves accountable for achieving results, and are capable of self-direction and self-control. (p. 825-826)

Russ (2011) noted that, "theory Y managers usually assume employees are motivated to meet higher-order needs through accomplishing meaningful work, being involved in making work-related decisions, and providing valuable input to enhance an organization's effectiveness" (p. 826). In this light, the leader operationalizing theory Y as their management style, were empowering subordinates and fostering a sense of professionalism that was positively impacting the organization. Theory $\mathrm{X}$ did quite the opposite by leaving the subordinate deprofessionalized and deskilled. 
Utilizing theory $\mathrm{Y}$ as a management platform, principals led educational organizations and recognized that teachers as professionals added to enrich the educational organization. When professional goals and organizational goals aligned, both the teacher as the professional and the organization benefited greatly. School leaders who operationalized theory $\mathrm{Y}$ in their management strategies help to support and promote a professional culture within their organization.

\section{Principals and Power}

Warren (1969) hypothesized that "in a given organization the combinations of power base and peer group that show complementary types of conformity will achieve the highest level of social control and conformity to organization goals" (p. 544). His study utilized the power bases as developed by French and Raven (1960) and focused on the interactions of power between the power agent and the subordinates. Warren noted that "power bases tend to elicit behavioral or attitudinal conformity" (p. 548). Recognizing that when the superiors use of power interacts positively with the subordinates experiences and expectations, both the superiors and the subordinates contributed towards providing the highest level of support to promote and meet organizational goals.

Lymas (1992) studied how middle school and high schools principal's use of power related to teacher satisfaction with work and their principal. The study revealed that teachers' dissatisfaction with work and their principal was prevalent when principal's used coercive power, connection power, and reward power. She noted that high school principals used more referent power and expert power to influence, and relied little on coercive power or reward power. 
In a study examining teacher participation in school decision making, Smylie (1992) assessed factors influencing teachers' willingness to participate in school decision making. He observed that “teachers' participation in decision making gave administration access to critical information closest to the source of many problems of schooling” (p. 53). With such increased access school administrators were able to make informed decisions thus positively impacting the quality of decisions. Teachers were empowered to impact decisions made and were provided that opportunity when the principal allowed and supported an open line of communication. Smylie (1992) provided as a discussion point that:

Teachers appear substantially more willing to participate in all areas of decision making if they perceive their relationships with their principals as more open, collaborative, facilitative, and supportive. They are much less willing to participate in any area of decision making if they characterize their relationships with principals as closed, exclusionary, and controlling. (p. 63)

Studies investigating teacher job satisfaction in relation to the principal's use of power revealed that teachers whose perception of their principal is positive tend to experience high job satisfaction. Schultz's research (1986) discovered that a statistically significant relationship existed between the teachers' job satisfaction and their perception of their principals' use of referent, legitimate, expert, and information power. Furthermore, teachers low job satisfaction was linked to the principals' use of coercive and connection power.

DeRose (1985) critically examined the relationship between perceived power used by secondary principal and the degree of teacher alienation and failed to yield a 
significant relationship between the number of power bases and the degree of alienation. However, after conducting a canonical correlation analysis, she discovered a positive relationship between the principals' use of referent and expert power and the teachers' level of enhanced involvement. Furthermore, social isolation and lack of power were found in teachers who worked in schools where the principals experienced high levels of stress. Results of this study concluded that principals use of power and levels of stress can significantly impact teachers' involvement and perceptions of their principal.

The examination of the seven bases of power and the strategies utilized to implement power helps to provide insight of how educational leaders impact teachers' self-perception of professionalism. Defining power as the capacity or potential to influence, the examination of the relationship between the principal and the teacher through both the LMX Theory and Theory X/Y helped contextualize how the principal can influence the teacher. Educational leaders who had an understanding of how their use of power impacted subordinates began to foster an organizational culture that valued and supported teachers as professionals.

\section{Summary}

This study, sought to examine the relationship existent between the principal's use of power and the teacher's self-perception of professionalism, recognizes that existent between the principal and the teacher was a relationship influenced by factors from both perspectives. A brief literature review outlining professionalism as it pertains to the teacher provided both a structural and attitudinal perspective (Hall, 1968). An examination of deprofessionalization incorporated present educational practices that can create feelings of intensification and deskilling. Intensification accounted for pressures 
placed on teachers to perform and execute tasks within a prescribed time frame.

Deskilling addressed state and local mandates that created prescriptive curricular tools, fabricate professional development models, leading to drained autonomy and creativity of the teacher as a professional, and negatively impacted the teachers' self-perception of professionalism.

The exploration of the bases of power as described by French and Raven (1959), Raven and Kruglanski (1975), and Hersey, Blanchard, and Natemeyer (1979) provided a means of accomplishing organizational tasks and directions through the principal's role as educational leader. The leader-member exchange theory (Northouse, 2010) and McGregor's (1960) theory X-theory Y, provided a useful frame to examine the relationship between both the principal and the teacher. Since the publication of $A$ Nation at Risk, education as a profession has been under extreme criticism, endeavoring to establish itself as a true profession. University teacher preparation programs have increased rigor, certification standards have been raised, and educational leaders have made great strides in establishing the profession of education.

The role and impact that the principal as the school leader has on the teacher as a professional is of great significance. As the teacher-professional strives to establish him or herself as just that, a professional, the principal must be cognizant of how he or she impacts such an establishment as well as how he or she can be supportive in helping teachers reach their own professional goals. A reciprocal relationship between the organization and the teachers must be fostered. The principal, as the school leader, can ensure that such reciprocity thrives in providing an environment where organizational 
goals are stated and communicated clearly, as well as supportive of the teachers own professional goals.

Chapter Three provides the research design and methodology used to conduct this study. Sections outlining the purpose and overview of the study; methodology used; population and sample description; data collection procedures and instrumentation; data analysis; validity; research biases and assumptions are included. Quantitative findings and analysis are presented in Chapter Four. Finally, Chapter Five outlines the findings and suggestions for future research. 


\section{CHAPTER THREE \\ RESEARCH DESIGN AND METHODOLOGY}

\section{Introduction}

For public education, power and professionalism create a bit of a conundrum. Power is pervasive and complex and can often times be disguised within society. French and Raven (1959/2011), “define power in terms of influence, and influence in terms of psychological change" (p. 298). Power when used by individuals impact behaviors, opinions, attitudes, goals, needs, values, and all other aspects of a person's psychological field, encompassing the characteristic of change that French and Raven refer to when considering influencing through the utilization of power.

The application of such influence, when used by a principal in the public education setting, challenges the very concept of professionalization. "A professional may be defined simply as a person possessing technical competence within a specialized occupational area" (Willower, 1960, p. 73). Willower (1960) posed the question, "How does the person who regards himself as a professional relate to those in formal leadership positions in his organizations? Does the professional prefer certain leadership styles?" (p. 74). Willower's study Professionalization and Education publicized in the world of research the importance of the professionalization of school personnel, and in many respects began the conversation in regards to the teacher as a professional.

The following sections provide details pertaining to the research design and methods utilized to carry out this study. Three research questions were utilized to examine the relationships between the principals use of power and teachers self- 
perception of professionalism. For the purpose of this study a quantitative means of data collection was developed utilizing a survey instrument distributed to a sample group of certified secondary (grades 9-12) classroom teachers in the state of Missouri.

Provided is a description of how the sample was selected from the population of certified secondary classroom teacher. Following is a description of the survey instrument developed for this study and the data analysis methods used. The researcher addresses reliability, validity, limitations, and assumptions of this study. This study explored the relationship between the principals' use of power and the impact such power has on the teachers' self-perception of professionalism. Furthermore, the data gathered enabled both educational leaders and teachers as professionals to support both organizational and professional goals.

\section{Purpose of the study}

The purpose of this quantitative correlational study was to determine the relationship between principals' use of power, and teachers' self-perception of professionalism within public high schools in the state of Missouri. The significance of the research was that it may enhance the knowledge and skills of how principals can promote and foster a sense of professionalism through their use of power. The research questions addressed teachers' perceptions of principals' use of power as well as how teachers self-perceived professionalism (Cheng, 1996; Sockett, 1993 and Tichenor \& Tichenor, 2005). 


\section{Research Questions}

1. As perceived by teachers, how do secondary principals use power?

2. How do secondary teachers view themselves as professionals?

3. What is the relationships between the teachers' perception of the principal's use of power and their self-perceptions of professionalism?

a. What base of power used by principals is directly related to teachers' selfperception of professionalism?

b. What base of power used by principals is inversely related to teachers' self-perception of professionalism?

\section{Design of the Study}

This research project was a quantitative study to explore the relationship that existed between the principal's use of power and the teacher's self-perception of professionalism. For the purpose of this study, the principal's use of power was identified as the predictor variable while the teacher's self-perception of professionalism will be identified as the criterion variable (Salkind, 2010).

The development of the survey tool, the Self-Perception of Professionalism Inventory adapted from the work of Hall, (1967); Sockett, (1993); Tichenor and Tichenor, (2005, 2009); and Robinson, (2008), was used to gather data concerning the teachers' self-perception of professionalism. The Power Perception Profile (PPP) as developed by Hersey, Blanchard, and Natemeyer (1979), was utilized to gather data pertaining to the teachers' perception of their principals' use of power. This researcher intended to utilize the above mentioned tools to gather quantitative data to examine if a 
correlation existed between the principals use of power and teachers self-perception of professionalism.

\section{Population and Sample}

The population from which the sample was drawn includes all secondary public school classroom teachers located within the state of Missouri. According to the 20112012 Statistics of Missouri Public Schools (DESE, 2012, p. 1), there were 609 public high schools located in Missouri which employed approximately 567 high school principals, 560 assistant high school principals, and 20,050 classroom teachers. Due to the breadth of the population this researcher felt it appropriate to utilize a convenience means of selecting the sample, selecting high schools that were close in proximity to the researcher.

The convenience sample consisted of schools located in Southwest Missouri and part of the Central Ozark Conference (COC). The COC was made up of two divisions, large and small and included a total of fifteen high schools. The large COC consisted of the following high schools: (a) Branson - 101 teachers, (b) Carthage -134 teachers, (c) Neosho - 106 teachers, (d) Nixa - 133 teachers, (e) Ozark - 114 teachers, (f) Republic 91 teachers, (g) Webb City - 90 teachers, and (h) Willard - 101. The large COC included a total of 870 teachers. The small COC consisted of the following high schools: (a)

Bolivar - 76 teachers, (b) Buffalo - 64 teachers, (c) Hollister -46 teachers, (d) Rogersville - 55 teachers, (e) Marshfield - 75 teachers, (f) Reeds Spring - 64 teachers, and (g) Catholic 26 teachers. The small COC included a total of 406 teachers. The total sample size utilized for this study was 1,276 high school teachers. 


\section{Data Collection and Instrumentation}

Data was collected through the administration of an on-line survey tool. Once appropriate permissions were granted, the on-line survey was distributed to a sample group of secondary classroom teachers as described in the previous section. The following section articulates the data collection procedures employed and provides a description of the instruments utilized in this study.

Data collection procedures. The procedures for collecting data for this study included: (a) obtaining appropriate permission to conduct the study both from the high schools administration (see Appendix D), (b) upon approval the researcher provided building administrators with the necessary information and materials to electronically distribute to classroom teachers, (c) teachers received an email, with an informed consent page imbedded (see Appendix E) briefly outlining the study and a link to navigate to the survey tool, and (d) a timeline indicating the deadline for completing the survey was provided.

First, the researcher provided each high school's principal in the research study a cover letter (Appendix D) outlining the purpose of the study, means of data collection, a copy of the informed consent teachers would be provided (Appendix E), and an example of the survey instrument. Second, once the high school administrative approval was granted the researcher provided the building administrator with a template email to be distributed to all certified classroom teachers. The template email provided teachers a brief introduction to the purpose of the study, a link to gain access to the informed consent and survey tool, and provided the teacher a deadline for survey completion. Once teachers gained access to the informed consent letter they were prompted to either 
accept or decline participation in the study. If they accepted the terms they were directed to the survey tool. If the teacher declined participation in the study they were prompted to confirm that they elected not to participate and were directed to close the browser.

Finally, at the end of the indicated timeline, the researcher examined the data received and decided if the number of respondents was enough for analysis. If necessary, the researcher contacted the building administrators and requested that a reminder email, provided by the researcher, be sent out to all certified teaching staff.

Survey Instruments. For the purpose of this study two instruments were combined to collect data to examine the relationship between the principals' use of power and the teachers' self-perception of professionalism. The online survey tool entitled, Power and Professionalism (Appendix A) combined two inventories to address the research questions developed for the purpose of this study. The Teacher Professionalism Inventory - Self (Appendix B) was adapted from the work of Tichenor and Tichenor (2005), Cheng (1996) and Sockett (1993) and was utilized to address how teachers' selfperceived professionalism. The Power Perception Profile-Perception of Other (Appendix C) as developed by Hersey, Blanchard, and Natemeyer (1988) was utilized to gather data pertaining to the teacher's perception of the principal's use of power.

Power Perception Profile-Perception of Other (PPP). The Power Perception Profile-Perception of Other (Appendix C) was developed by Hersey, Blanchard, and Natemeyer (1979) as a means of providing leaders with feedback as it pertained to the power bases they utilized. Two versions of this profile are available: self-perception profile and perception of others profile. For the purpose of this study the researcher has 
selected the use of the perceptions of others profile as a means of gathering data from the teachers perspective.

The PPP contains twenty-one forced-choice pairs of reasons often given by people when asked why they do things that a leader suggests or wants them to do. Each statement reflects one of the seven sources of power; coercive power, connection power, expert power, information power, legitimate power, referent power, and reward power. Respondents are asked to distribute three points between each set of two choices, responding from their perception of why they comply with the leaders particular instructions. (Hersey et. al., 1979, p. 426) Teacher Professionalism Inventory of Self. The survey tool Teacher Professionalism Inventory of Self was developed by Tichenor and Tichenor (2009) in conjunction with their previous work (Sockett, 1993; Tichenor \& Tichenor, 2005) and analysis of a survey on teacher professionalism developed by Cheng (1996).

A survey instrument was developed that asked teachers and administrators to describe the priority teacher place on a wide variety of behaviors and characteristics. The 51 survey items are categorized into four dimensions of professionalism: personal characteristics, commitment to change and continuous improvement, subject and pedagogical knowledge, and participation in educational activities beyond the confines of the classroom. (Tichenor \& Tichenor, 2009, p. 11)

For the purpose of this study the researcher combined the components of each of the above-described instruments into an online survey tool entitled Power and Professionalism (Appendix A) to gather data relevant to this study. The online survey 
instrument was designed utilizing a seven point Likert scale for questions relevant to the Teacher Professionalism Inventory of Self (Appendix B) and utilized the four dimension of professionalism (Sockett, 1993; Tichenor \& Tichenor, 2005) as subscales for analysis. The questions relevant to the Power Perception Profile-Perception of Other (Appendix C) utilized a zero to three point distribution for a forced pair choice, addressing the seven bases of power as described in this study. The Power and Professionalism Survey was anticipated to take approximately fifteen minutes to complete.

\section{Reliability and Validity}

Reliability and validity of the survey instrumentation utilized in this study have been addressed by the researcher's utilization of measures that have been tested and retested. The Power Perception Profile (PPP) developed by Hersey, Blanchard, and Natemeyer (1979) has been utilized multiple times (Elliot, 1992; Turman, 2001; and Kelly \& Tazbir, 2013) to measure subordinates perception of leader's use of power.

The four dimensions of professionalism adapted for the purpose of this study were built on the results of focus group interviews with teachers (Tichenor \& Tichenor, 2005) as well as a survey on teacher professionalism developed by Cheng (1996) and constructed into a survey instrument by Tichenor and Tichenor in 2009. "After the survey was piloted and revised, teachers from eight elementary schools in one county in central Florida were selected to participate. A total of 216 surveys were collected from the teachers at eight schools" (Tichenor \& Tichenor, 2009). There were statistically significant differences of note on 19 of the 51 items describing various dimensions of professionalism. It was the recommendation of Tichenor and Tichenor (2009), that this survey tool be utilized on a larger sample in order to confirm or support generalizability. 


\section{Human Subjects Protection}

In order to ensure the protection of human subjects, certification to conduct research using human subjects was obtained by the researcher through the Collaborative Institutional Training Initiative (CITI) and is endorsed by the researcher's attending university. Upon completion of CITI training the researcher submitted a research proposal to the university's Institutional Review Board (IRB) which outlined the: (a) purpose of the study, (b) procedures of the study, (c) provided all consent forms, (d) letters of permission or support requesting participation, (e) data monitoring safety plan, and (f) questionnaires, handouts, or any other applicable instruments. Subjects responses were anonymous as there were no disclosures or identifiable data collected that would link back to any certain individuals.

\section{Data Analysis}

The data collected from the survey instrument was analyzed using IBM Statistics (SPSS) Version 19. The following research questions: (1) How is the principals' use of power perceived by secondary teachers?: and (2) How do secondary teachers view themselves as professionals were examined through quantitative analysis utilizing descriptive statistics, examining means in descending order and the standard deviation as processed by SPSS. Furthermore, research question three "what is the relationship between the teachers' perception of the principal's use of power and their self-perception of professionalism" had been examined utilizing Pearson's correlation coefficient, examining the relationship between the two variables: power and professionalism. 


\section{Research Question One}

Results from The Power Perception Profile-Perception of Other (Appendix C) provided data from the teacher's perception of the school leader's use of the seven types of power as described French and Raven (1959/2011) and expanded upon by Hersey, Blanchard, and Natemeyer (1988). The seven power bases included: (a) coercive power, (b) connection power, (c) expert power, (d) information power, (e) legitimate power, (f) referent power, and $(\mathrm{g})$ reward power. A table of subscale means, presented in rank order, created a power profile of principals in the study as perceived by the secondary teacher.

\section{Research Question Two}

The Teacher Professionalism Inventory of Self (Appendix B) adapted from the work of Tichenor and Tichenor (2005), Cheng (1996) and Sockett (1993) provided data addressing the teachers' self-perception of professionalism and was organized utilizing four subscales: (a) personal characteristics, (b) commitment to change and continuous improvement, (c) subject and pedagogical knowledge, and (d) participation in educational activities beyond the confines of the classroom" (Tichenor \& Tichenor, 2009, p. 11). A table of subscale means, presented in rank order, created a self-perception of professionalism profile of the teachers in the study.

\section{Research Question Three}

By examining a correlation matrix produced from the data the researcher was able to examine if correlations existed between the criterion variable and the predictor variable, i.e., power and professionalism. To further establish understanding of the relationship existent between the two variables the researcher standardized the covariance by means of the Pearson correlation coefficient (Field, 2009; Salkind, 2007). "A 
coefficient of +1 indicates that two variables are perfectly positively correlated, so as one variable increases, the other increases by a proportionate amount. Conversely, a coefficient of -1 indicates a perfect negative relationship: if one variable increases, the other decreases by a proportionate amount. A coefficient of zero indicates no linear relationship" (Field, 2009, p. 170). The researcher used a forward multiple regression as a means to create a prediction model for each subscale of professionalism using power bases as the predictors.

\section{Limitations and Assumptions}

\section{Limitations}

Due to the large population represented in this study the researcher utilized a means of selecting a sample size that was representative of the whole. While the sample size is sufficient, due to the systematic means of selecting participants generalizability of the findings might be limited. The study is limited to secondary principals and teachers, limited to one Missouri state, and limited to quantitative measures of the variables under investigation. While participation in the study was voluntary, responses were confidential and cannot be linked to an identifiable respondent, it was possible that teachers could have been hesitant to respond truthfully with reservation that their principal would find out. Teachers were assured of anonymity. The data collection instrument was adapted by this researcher, utilizing research from current contributors, in order to ensure that data was collected that addressed the research questions.

\section{Assumptions}

Several assumptions were taken into consideration concerning this study. It was assumed that teachers responded truthfully to the questions on the survey tool. This 
study included a sample from a population of approximately 20,020 high school classroom teachers within the state of Missouri, and it is the assumption of this researcher that, since the building administrator disseminated the online survey tool to all classroom teachers within the high school building, only certified classroom teachers received invitation to participate in the study. An additional assumption was that the phenomenon under investigation, power and professionalism, could be measured. Finally, it was assumed that teachers responded to the survey thoughtfully and accurately.

\section{Summary}

This correlational study was constructed utilizing a quantitative design. The researcher identified the independent variable as being the principal's use of power and the dependent variable being the teacher's self-perception of professionalism. The researcher set out to examine if a relationship exists between the independent and dependent variables utilizing a survey instrument that combined the Power Perception Profile-Perception of Other (Appendix C) as developed by Hersey and Natemeyer (1988) and the Teacher Professionalism Inventory - Self (Appendix B) adapted from the work of Tichenor and Tichenor (2005), Cheng (1996) and Sockett (1993). The sample group, from a population of approximately 20,020 secondary classroom teachers, was selected through a means of convenience sampling, resulting in a sample size of approximately 925 certified, secondary classroom teachers.

Once the districts were selected for participation, the researcher contacted each superintendent to gain access to the selected high schools. Upon approval of the superintendent the researcher contacted the high school principal(s) requesting approval to provide opportunity for secondary classroom teachers to participate in the study. Once 
approval was granted by the high school principal the researcher provided the principals with a template email that contained a cover letter outlining the purpose and procedures of the study, informed consent, and a link to access the survey instrument.

When the informed consent and surveys were returned the researcher performed quantitative analysis examining means in descending order as well as standard deviation. Utilizing SPSS the researcher inputted the survey responses to allow for analysis. The analysis of the data was made to examine if a relationship exists between the principal's use of power and the teacher's self-perception of professionalism. 


\section{CHAPTER FOUR}

\section{RESEARCH DATA ANALYSIS}

\section{Purpose}

The purpose of this study was to examine the relationship between principals' use of power and teacher's self-perception of professionalism. Goodson and Hargreaves (1996) addressed that, "what teachers think about professionalism or what they experience under its name are addressed too rarely" (p. vii). This study sought to examine the relationship that existed between the principals' use of power and the teacher's selfperception of professionalism. Seven bases of power were explored for the purpose of this study. Five bases adapted from French and Raven (1959), include; (a) reward power, (b) coercive power, (c) legitimate power, (d) referent power, and (e) expert power. Information power (f) was introduced by Raven and Kruglanski (1975), and (g) connection power was incorporated by Hersey, Blanchard, and Natemeyer (1979).

The examination of the teachers' self-perception of professionalism encompassed four dimensions of professionalism: (a) personal characteristics, (b) commitment to change and continuous improvement, (c) subject and pedagogical knowledge, (d) participation in educational activities beyond the confines of the classroom (Tichenor \& Tichenor, 2009; Sockett, 1993). By examining the relationship existent between the principal's use of power and teachers self-perception of professionalism, it was the intention of this researcher to provide data that would inform educational leaders of how to support professionalism within the organization as an entity and the field of education as a whole. 


\section{Research Questions}

Through a thorough examination and review of related literature, the understanding of how the principals' use of power related to the teacher's self-perception of professionalism was discovered to be limited. The development of the research questions provided the researcher means to collect relevant data in order to better examine the principals' use of power in relation to the teacher's self-perception of professionalism. The following research questions were utilized to guide this study:

4. As perceived by teachers, how do secondary principals use power?

5. How do secondary teachers view themselves as professionals?

6. What is the relationships between the teachers' perception of the principal's use of power and their self-perception of professionalism?

a. What base of power used by principals is directly related to teachers' selfperception of professionalism?

b. What base of power used by principals is inversely related to teachers' self-perception of professionalism?

\section{Research Methods}

This quantitative research study examined the relationship between the independent variable, the principal's use of power, and the dependent variable, the teacher's self-perception of professionalism (Creswell, 2009). Utilizing a convenience means of sampling (Fink, 2009), approximately 1,276 certified secondary teachers were selected from a population size of approximately 20,020 certified secondary classroom teachers within the state of Missouri. 
Once the convenience group was selected the researcher provided the respective high school principals with a letter that outlined the purpose of the study and requested permission to utilize faculty under their leadership to participate in the study. After approval was granted to gather data to address the research questions presented in this

study, the researcher utilized an online survey that was disseminated to the teachers in the sample group through the high school principals.

The online survey tool created for the purpose of this study was entitled Power and Professionalism and combined two inventories to address the research questions developed for the purpose of this study. The Teacher Professionalism Inventory - Self (Appendix B) was adapted from the work of Tichenor and Tichenor (2005), Cheng (1996) and Sockett (1993) and was utilized to address how teachers' self-perceived professionalism. Furthermore, the Power Perception Profile-Perception of Other (Appendix C) as developed by Hersey, Blanchard, and Natemeyer (1988) was utilized to gather data pertaining to the teacher's perception of the principal's use of power.

\section{Data Demographics and Analysis}

The purpose of this study was to examine the relationship between the high school principal's use of power and the teachers' self-perception of professionalism. Requests for permission to distribute the Power and Professionalism Inventory were sent to 15 high school principals, members of the Central Ozark Conference (COC) in the state of Missouri. Once permission was granted, principals were provided a template email containing a link to access the inventory which they forwarded to their certified high school teachers. 
The survey was distributed to approximately 925 certified high school teachers throughout the Central Ozark Conference. This chapter provides results from a total of 132 surveys that were completed in their entirety by certified high school teachers. The survey is made-up of two parts: (a) Power Perception Profile - Perception of Other (Appendix C), and the (b) Teacher Professionalism Inventory - Self (Appendix B). The Power Perception Profile was constructed of 21 forced-choice-pair responses, requiring the teacher to allocate a total point distribution of three between the two choices, validating which of the seven power bases the teacher perceived his/her principal to utilize in that instant.

After completing the Power Perception Profile, the teacher then proceeded to the second portion of the survey that consisted of the Teacher Professionalism InventorySelf. Forty-three questions were presented utilizing a Likert scale with six choices ranging from strongly disagree to strongly agree. For the purpose of this study professionalism consisted of four sub-scales: (a) personal characteristics, (b) commitment to change and continuous improvement, (c) subject and pedagogical knowledge, and (d) beyond the classroom. Table 1 provides an overview of the organization of research questions and the survey tool utilized to gather data.

The Statistical Package for Social Sciences (SPSS, Version 19) was utilized to analyze the data collected from the surveys completed by the participating teachers. An analysis of means in rank order as well as a Pearson correlation coefficient (Field, 2009) was completed to address research questions one and two. Research question three utilized a correlation matrix, examining relationships that were both inverse and direct between power and professionalism. 


\section{Table 1}

Organization of all Research Questions and Analyses

Research Questions Survey Subale Data Analysis
Questions

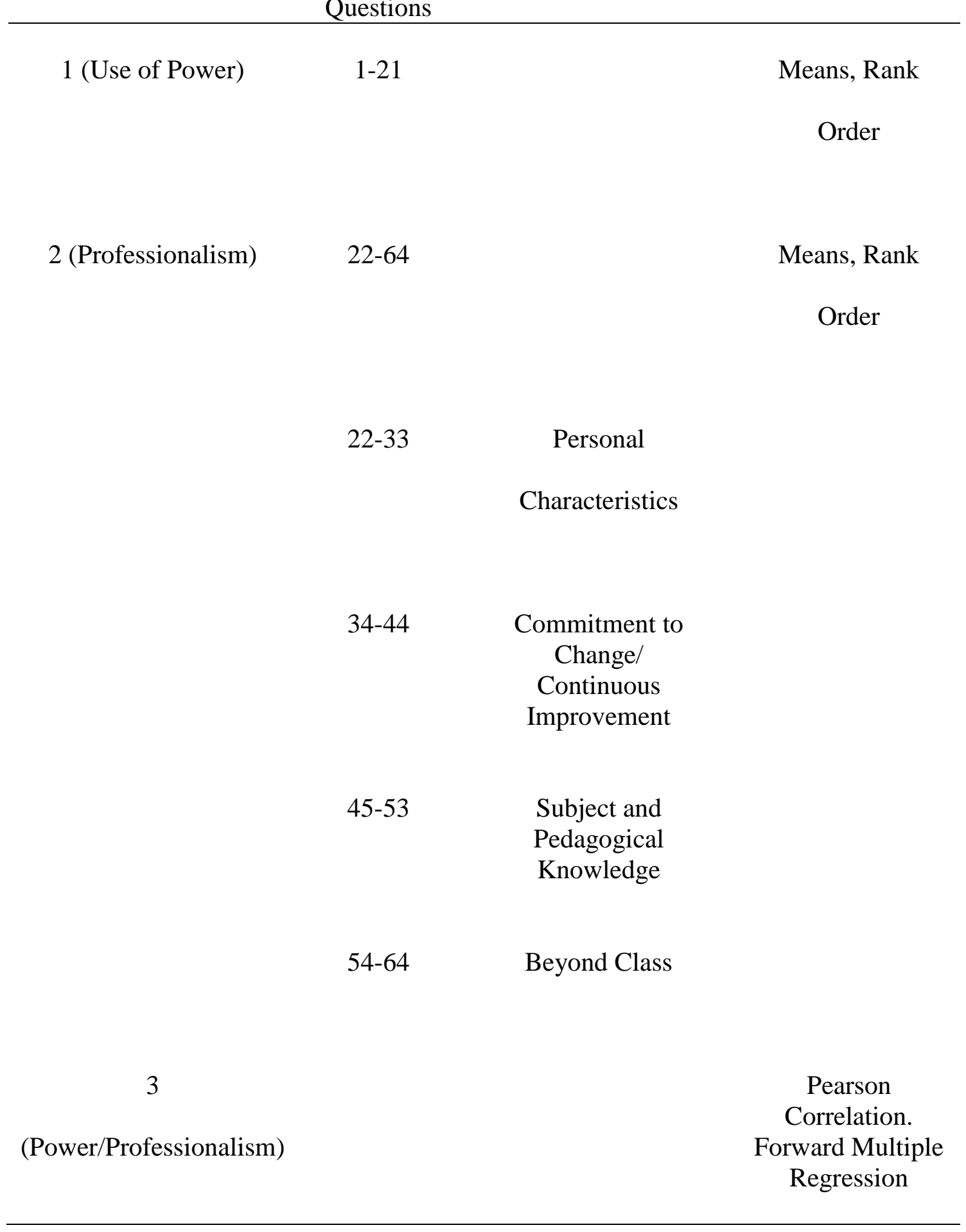




\section{Results for Research Question One}

The following data analysis provided findings addressing research question one, examining how principals used power as perceived by teachers. The seven bases of power examined included: (a) coercive power, (b) connection power, (c) expert power, (d) information power, (e) legitimate power, (f) referent power, and (g) reward power. Table 2 provides the subscale means, presented in ascending rank order. Furthermore, Table 2 provides frequency and percentage of distribution of points allocated by teachers utilizing 0-9 and 10-18 as the groupings. This grouping was selected because nine was the median points possible.

Table 2

Power Subscale Means in Ascending Order with Frequency and Percent Distribution as Perceived by Teacher

\begin{tabular}{|c|c|c|c|c|c|}
\hline Power Base & $N$ & Lower Use & Higher Use & Mean & Std. Deviation \\
\hline Connection Power & 144 & $112(77.8 \%)$ & $32(22.2 \%)$ & 6.81 & 3.68 \\
\hline Coercive Power & 138 & $119(73.2 \%)$ & $19(26.8 \%)$ & 7.62 & 3.87 \\
\hline Reward Power & 135 & $97 \quad(71.9 \%)$ & $38(28.1 \%)$ & 8.27 & 2.68 \\
\hline Referent Power & 137 & $69(50.4 \%)$ & $68(49.6 \%)$ & 8.82 & 3.77 \\
\hline Information Power & 135 & $66(48.9 \%)$ & $69(51.1 \%)$ & 9.53 & 2.92 \\
\hline Legitimate Power & 140 & $46 \quad(32.9 \%)$ & $94(67.1 \%)$ & 10.64 & 3.05 \\
\hline Expert Power & 145 & $46 \quad(31.7 \%)$ & $99(68.3 \%)$ & 11.42 & 3.51 \\
\hline Total Valid $N$ & 132 & & & & \\
\hline
\end{tabular}




\section{Connection Power}

The statement, "I realize that my principal has connections with influential and important persons," was used six times in forced-choice-pair responses. Represented by a mean score of 6.81 , respondents indicated that of the seven bases of power, connection power was the power least used as perceived by teachers. Of the 132 valid responses 112 or $77.8 \%$ of the teachers allocated nine points or less. The remaining 32 or $22.2 \%$ allocated 10 points or more, with a maximum point allocation of 18 . Figure 1 provides a graphic for the distribution of points concerning teacher's perception of their principals' use of connection power.

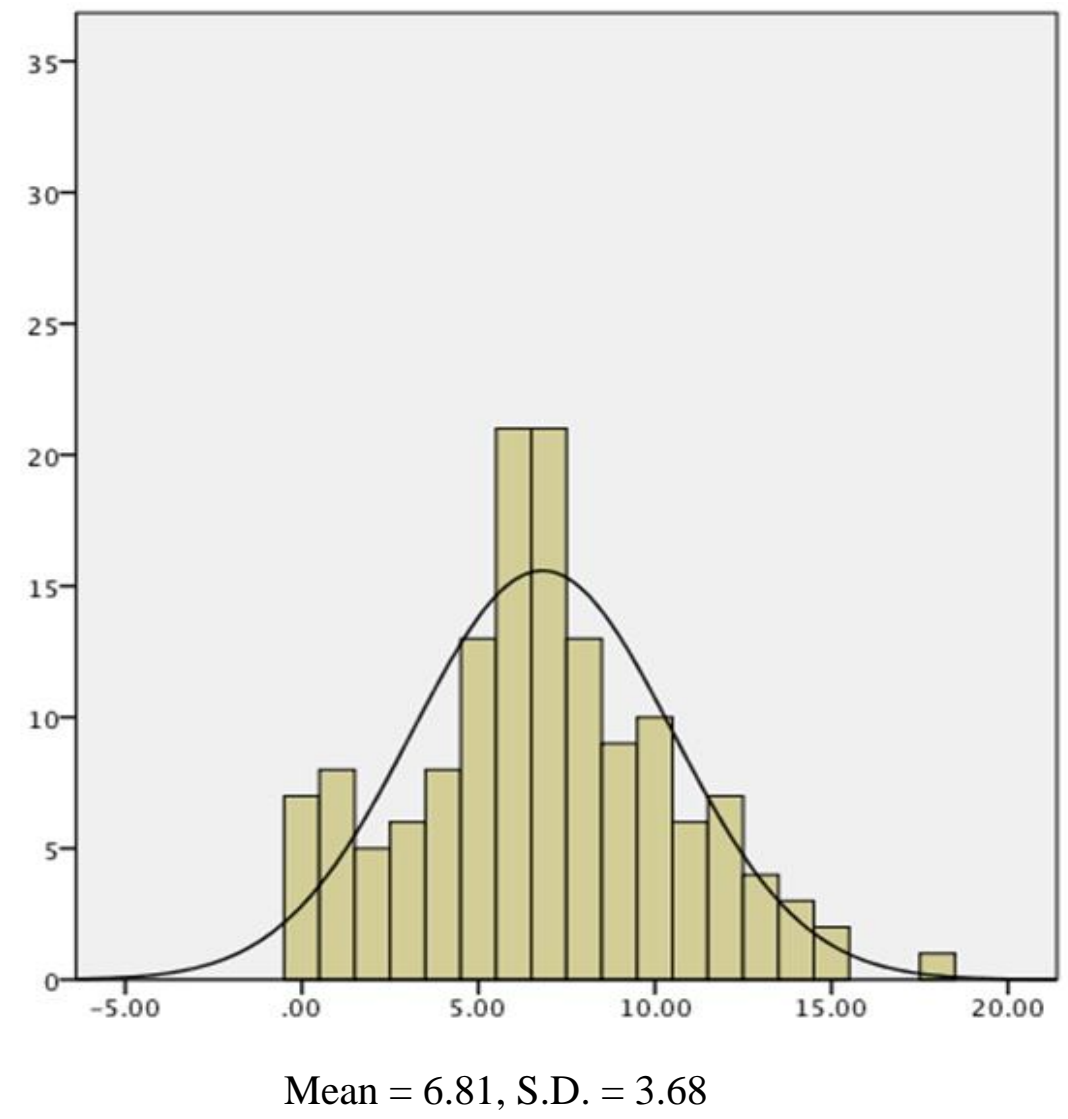

Figure 1. Distribution of responses for Principal use of connection power perceived by Teachers. 


\section{Coercive Power}

"My principal can administer sanctions and punishments to those who do not cooperate," was the statement utilized six times in forced-choice-pair responses. With a mean score of 7.62, the overall perception of teachers concerning their principals' use of power was that coercive power was used minimally. Of the 138 valid responses 119 or $73.2 \%$ of the teacher's allocated nine points or less. The remaining 19 or $26.8 \%$ allocated ten points or greater, with a maximum allocation of 18 . Of the 132 responses, two teachers perceived that their principals utilized coercive power over all the other power bases, allocating all 18 points. Figure 2 provides a graphic representation of the distribution in regards to coercive power.

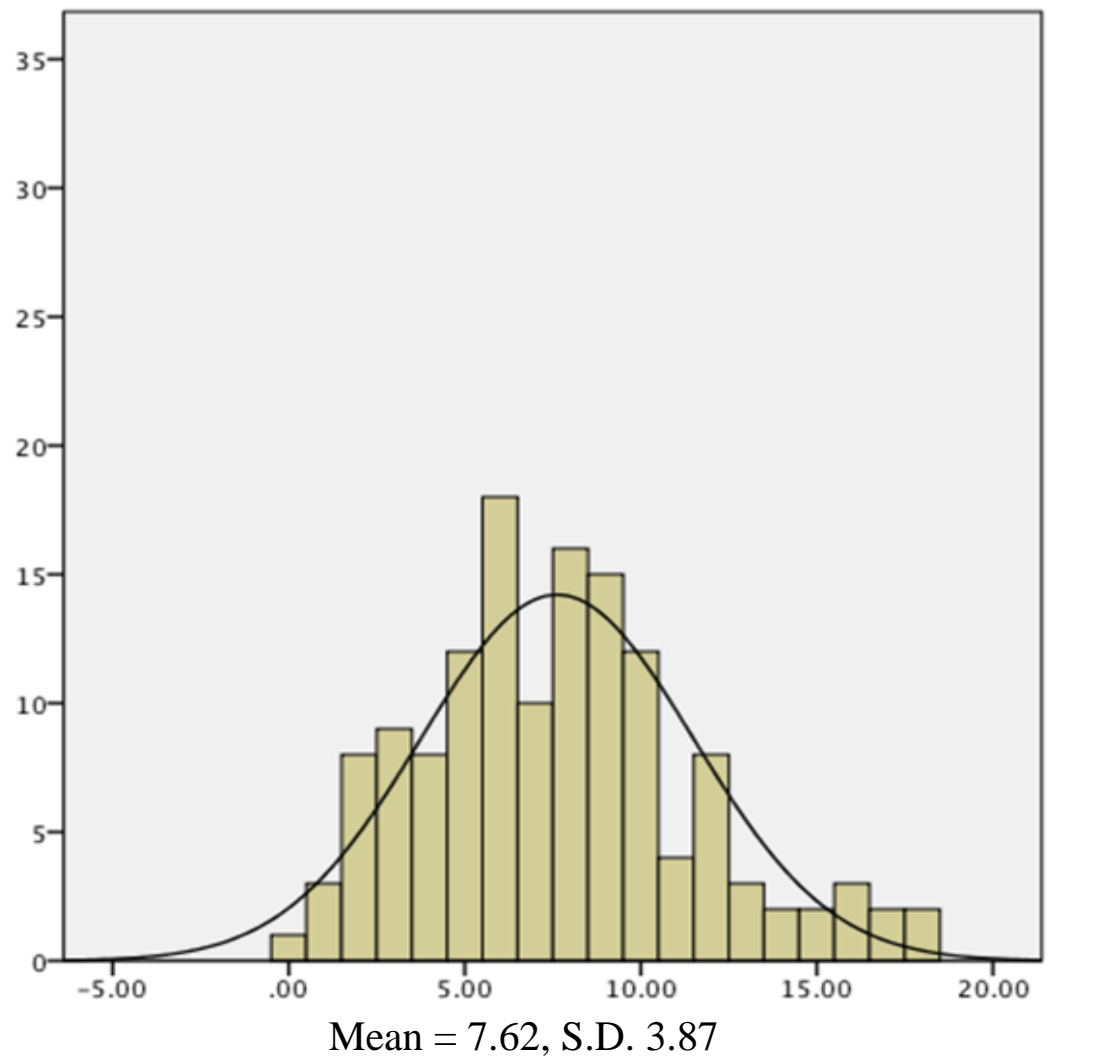

Figure 2. Distribution of responses for Principal use of coercive power as perceived by Teachers. 


\section{Reward Power}

Identified by the use of the following statement, "my principal can provide rewards and support to those who cooperate," reward power had a mean of 8.27. Of the 135 valid responses 97 or $71.9 \%$ of the teachers allocated nine points or less. The remaining 38 or $28.1 \%$ of teachers allocated ten points or more, with a maximum allocation of 18. Figure 3 provides a graphic representation of the distribution of responses in regards to reward power.

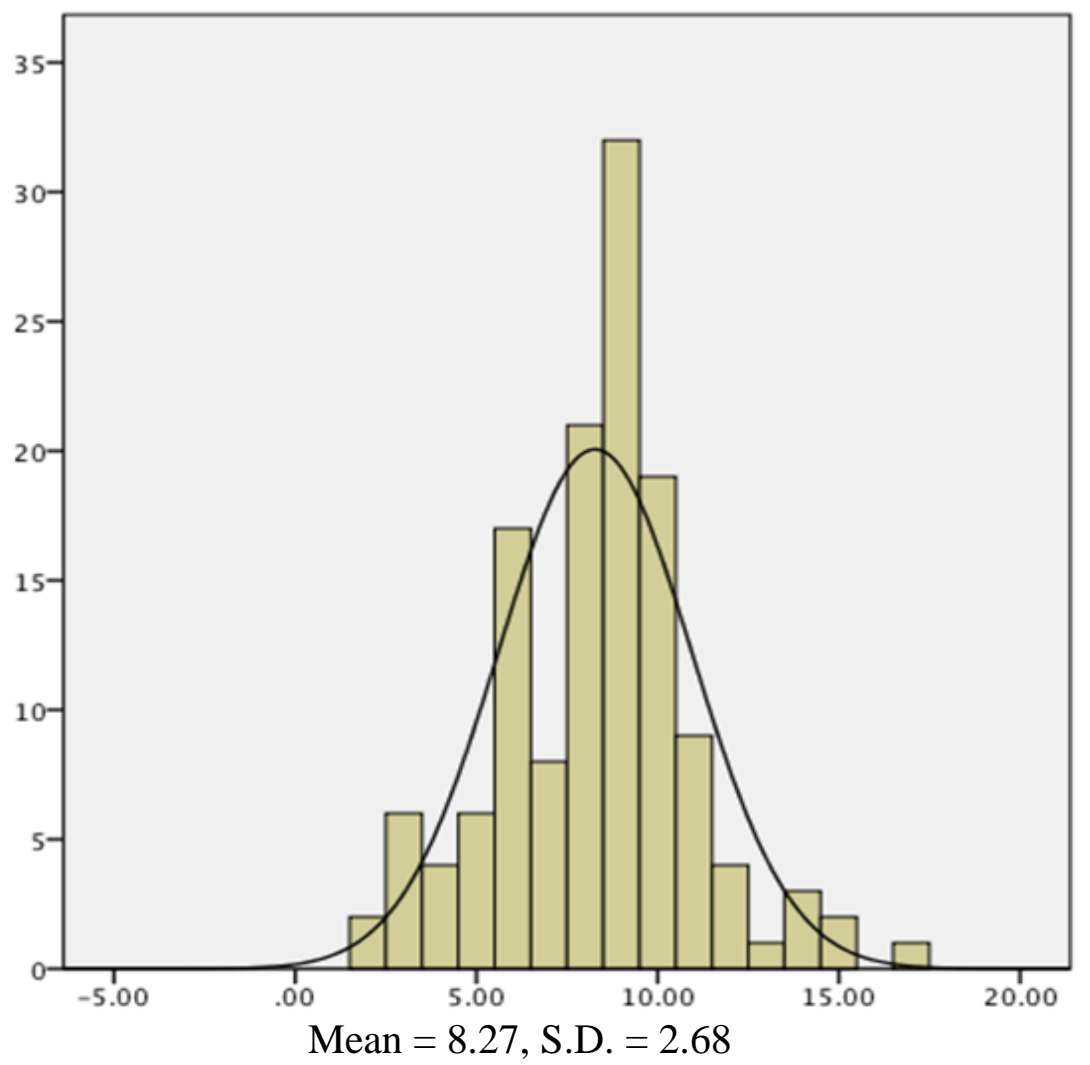

Figure 3. Distribution of responses for Principal use of reward power as perceived by Teachers. 


\section{Referent Power}

"I like my principal and want to do things that please him or her," was the statement combined in forced -pair-choice statements six times, providing teachers the opportunity to share their perceptions of their principals use of referent power. Of the 137 valid responses 69 or $50.4 \%$ of the teachers allocated nine points or less. The remaining 68 or $49.6 \%$ of the teachers allocated ten points or more, with a maximum of 17 out of 18 reached. Figure 4 provides a graphic representation of the distribution of responses in regards to referent power.

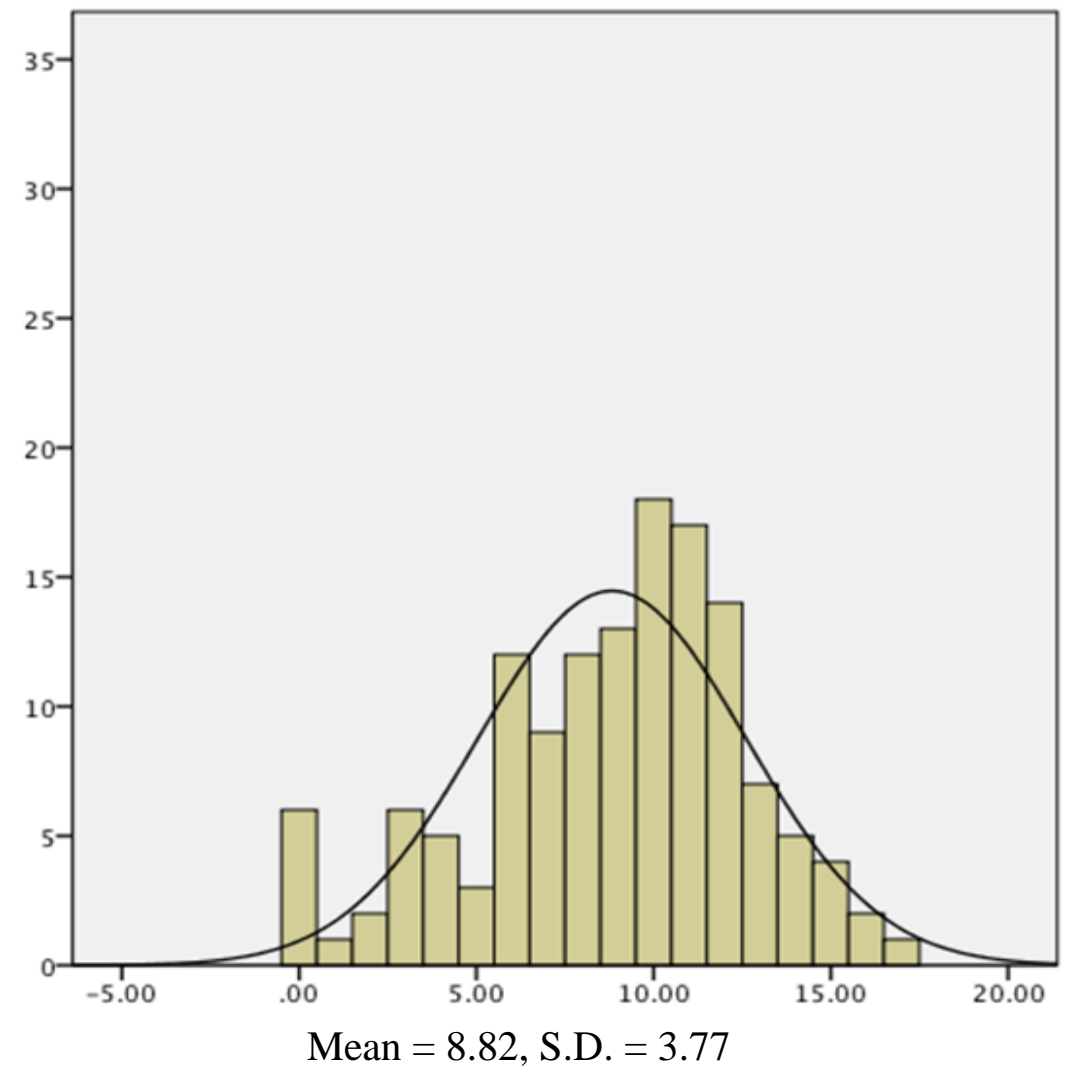

Figure 4. Distribution of responses for Principal use of referent power as perceived by Teachers. 


\section{Information Power}

Identified by the statement, "my principal possesses or has access to information that is valuable to others," information power returned a mean score of 9.53 . Of the 135 valid responses 66 or $48.9 \%$ of teachers allocated nine points or less. The remaining 69 or $51.1 \%$ of teachers allocated ten points or more, with a maximum of 18 points reached. Figure 5 provides a graphic representation of the distribution of responses in regards to information power.

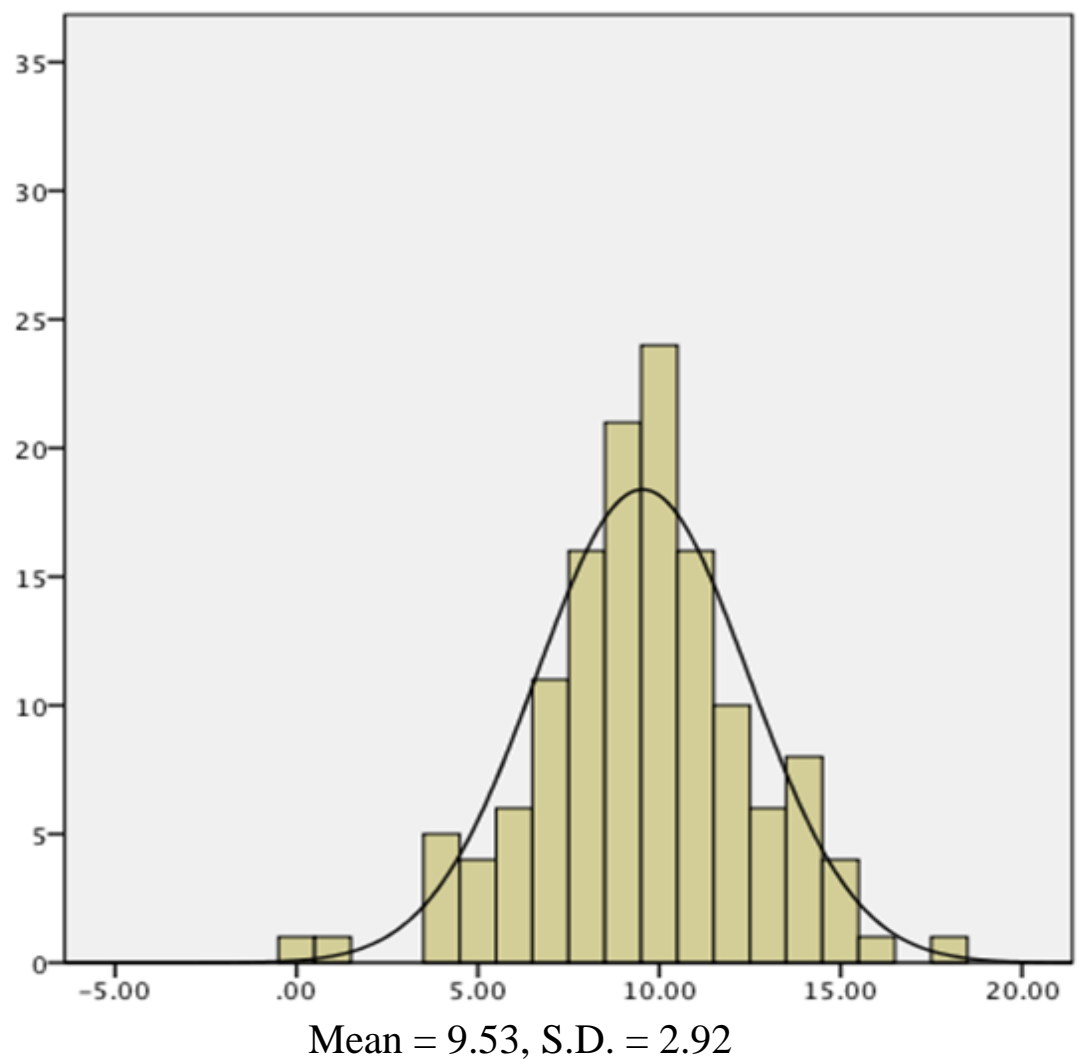

Figure 5. Distribution of responses for Principal use of information power as perceived by Teachers. 


\section{Legitimate Power}

"My principal's position in the organization provides him or her the authority to direct my work activities," was the statement utilized six times in forced-choice-pair responses. With a mean score of 10.64 , the overall perception of teachers concerning their principals' use of power was that legitimate power was perceived to be a power base used often by principals. Of the 140 valid responses 46 or $32.9 \%$ of the teacher's allocated nine-points or less. The remaining 94 or $67.1 \%$ of teachers allocated ten points or more, with a maximum allocation of 18 points. Figure 6 provides a graphic representation of the distribution in regards to legitimate power.

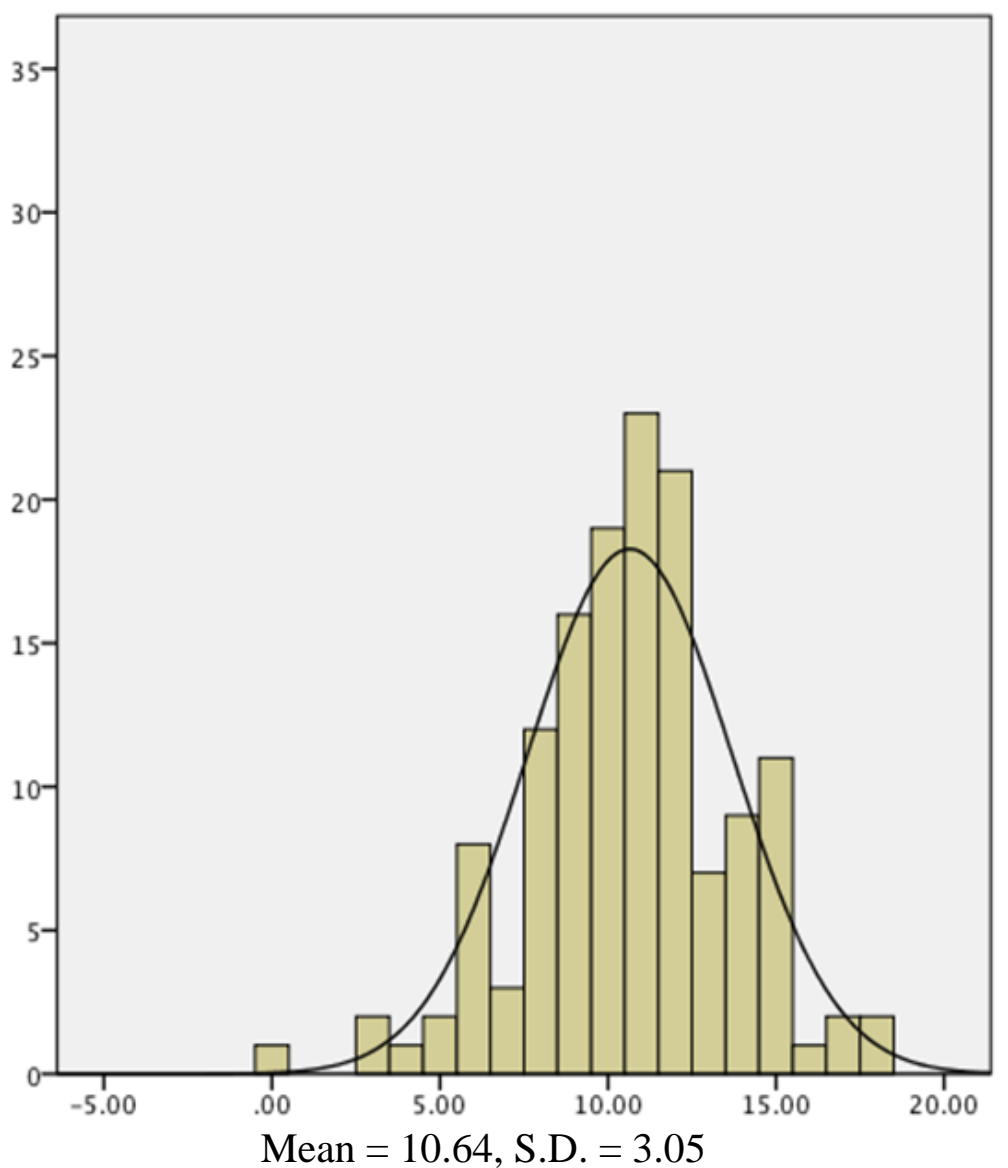

Figure 6. Distribution of responses for Principal use of legitimate power as perceived by Teachers. 


\section{Expert Power}

The statement utilized six times in forced-choice-pair responses for expert power was, "I respect my principals understanding, knowledge, judgment, and experience." With a mean score of 11.42, the overall perception of teachers was the expert power was perceived to be used most by principals. Of the 145 valid responses 46 or $31.7 \%$ of the teacher's allocated nine-points or less. The remaining 99 or $68.3 \% 81.4 \%$ of teachers allocated 10 points or greater, with a maximum allocation of 18 . Figure 7 provides a graphic representation of the distribution in regards to expert power.

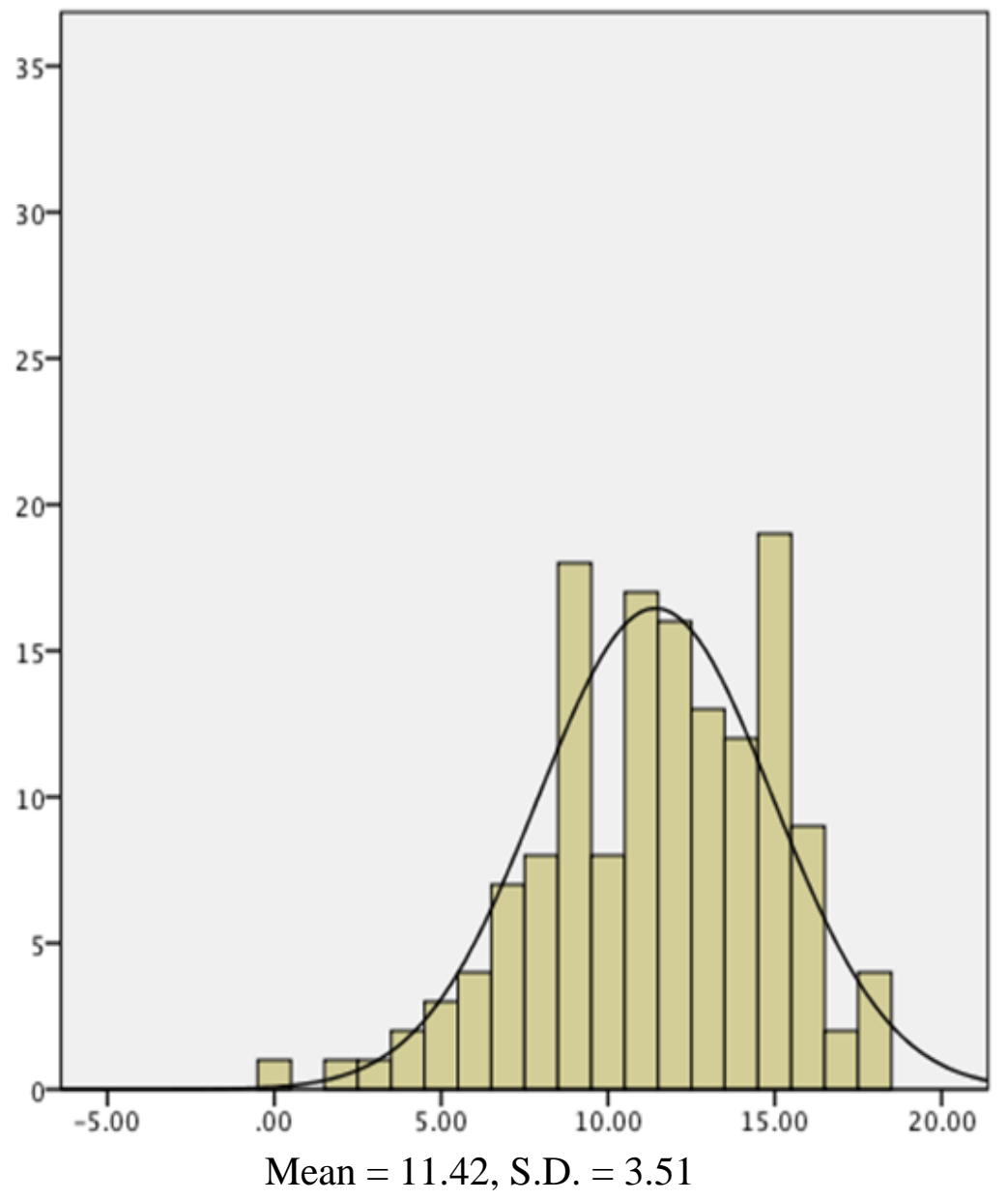

Figure 7. Distribution of responses for Principal use of expert power as perceived by Teachers. 


\section{Summary for Research Question One}

Quantitative data was collected to answer research question one, “As perceived by teachers, how do secondary principals use power?" Seven bases of power were explored using 21 forced-choice-pair responses, requiring teachers to allocate three points between two alternative reasons they perceived their principal used power. Based on the research question, teachers perceived that principals utilized all bases of power to some degree. It was also apparent when analyzing the items in conjunction with their pairs that no single power base was perceived to be used solely by the teachers' principal. Rather, they were used in tandem or in conjunction with another.

The seven bases of power explored: (a) connection power, (b) coercive power, (c) reward power, (d) referent power, (e) information power, (f) legitimate power, and (g) expert power were all represented to some degree. Connection power, coercive power, and reward power were perceived by teachers to be the least utilized by their principals, indicating that teachers perceived their principals as leaders who did not rely on connections had with other people to afford them the power they needed to lead. Neither did a large amount of teachers perceive their principals to administer sanctions, or punishments to those who did not cooperate. Furthermore, teachers did not perceive their principals to be leaders who provided rewards and support to those who cooperated with him/her.

A greater percentage of teachers perceived that their principals utilized information power, legitimate power, and expert power as a means of leading their organization. Teachers who perceived that their principal utilized information power agreed that their principal possessed or had access to information that was valuable to 
others. Legitimate power, teachers perceived that the principal's position in the organization provided him/her the authority to direct their work activity. The descriptor utilized for expert power and received the highest mean of the seven bases of power, indicated that teachers, "respect their principals understanding, knowledge, judgment, and experience." Table 3 provides the bases of power and the power perception descriptors used in the survey, listed in ascending order by means.

Table 3

Power Perception Profile Descriptors (presented in ascending order by means)

\begin{tabular}{ll}
\hline \multicolumn{1}{c}{ Power Base } & \multicolumn{1}{c}{ Profile Descriptors } \\
\hline Connection Power & $\begin{array}{l}\text { I realize that my principal has connection with influential and } \\
\text { important persons. (Mean = 6.81, S.D. = 3.68) }\end{array}$ \\
\hline Coercive Power & $\begin{array}{l}\text { My principal can administer sanctions and punishments to } \\
\text { those who do not cooperate. (Mean = 7.62, S.D. }=3.87 \text { ) }\end{array}$ \\
\hline Reward Power & $\begin{array}{l}\text { My principal can provide rewards and support to those who } \\
\text { cooperate. (Mean = 8.27, S.D. }=2.68 \text { ) }\end{array}$ \\
\hline Referent Power & $\begin{array}{l}\text { I like my principal and want to do things that please him/her. } \\
\text { (Mean = 8.82, S.D. = 3.77) }\end{array}$ \\
\hline Information Power & $\begin{array}{l}\text { My principal possesses or has access to information that is } \\
\text { valuable to others. (Mean = 9.53, S.D. = 2.92) }\end{array}$ \\
\hline Legitimate Power & $\begin{array}{l}\text { My principal's position in the organization provides him/her } \\
\text { the authority to direct my work activities. (Mean = 10.64, S.D. } \\
=3.05 \text { ) }\end{array}$ \\
\hline Expert Power & $\begin{array}{l}\text { I respect my principal's understanding, knowledge, judgment, } \\
\text { and experience. (Mean = 11.42, S.D. = 3.51) }\end{array}$ \\
\hline
\end{tabular}

Note. Higher scores indicate greater use of that type of power by principals, as perceived by teachers.

\section{Data Results for Research Question Two}

The following data analysis provided findings addressing research question two. "How do secondary teachers view themselves as professionals?" This research question provided results that addressed how secondary teachers viewed themselves as professionals utilizing four subscales. The four subscales of professionalism examined included: (a) commitment to change and continuous improvement, (b) beyond the 
classroom, (c) subject and pedagogical knowledge, and (d) personal characteristics.

Table 4 provides the subscale means, presented in ascending rank order. Furthermore, Table 4 provides the frequency and percentage of teachers who allocated $0-3$ on the Likert scale and 4-6. This division was made by the researcher to provide analysis of those teachers who disagreed with the professionalism statement compared with those who did agree with the statement.

Table 4

Professionalism Subscale Means for Teachers in Ascending Order as Self-Reported by Teachers

\begin{tabular}{|c|c|c|c|c|c|}
\hline & $N$ & Disagreement & Agreement & Mean & $\begin{array}{l}\text { Std. } \\
\text { Dev. }\end{array}$ \\
\hline $\begin{array}{l}\text { Commitment to } \\
\text { Change and Cont. } \\
\text { Improvement }\end{array}$ & 132 & $17(12.9 \%)$ & $115(87.1 \%)$ & 4.59 & .621 \\
\hline $\begin{array}{l}\text { Beyond the } \\
\text { Classroom }\end{array}$ & 132 & $3(2.3 \%)$ & $129(97.7 \%)$ & 5.13 & .479 \\
\hline $\begin{array}{l}\text { Subject/Pedagogy } \\
\text { Knowledge }\end{array}$ & 132 & $1 \quad(0.8 \%)$ & $131(99.2 \%)$ & 5.23 & .433 \\
\hline $\begin{array}{l}\text { Personal } \\
\text { Characteristics }\end{array}$ & 132 & $0 \quad(0.0 \%)$ & $132(100.0 \%)$ & 5.43 & .349 \\
\hline Valid $N$ & 132 & & & & \\
\hline
\end{tabular}

Commitment to Change and Continuous Improvement. Utilizing eleven sixpoint Likert scale responses, teachers were required to provide a response varying from strongly disagree to strongly agree, with no provision for a neutral response. Data collected indicated that of the four professionalism subscales, commitment to change and continuous improvement was the least emphasized, with a mean of 4.59. 
Table 5 articulates the statements utilized for commitment to change and continuous improvement and presents both the number of responses ranging from strongly disagree to somewhat disagree (0-3) and their percentage response rate, as well as the number of responses ranging from somewhat agree to strongly agree (4-6) and their percentage of response rate. For the purpose of this data analysis the researcher sorted the items in ascending order according to the somewhat agree to strongly agree (46) responses provided.

Items 43, 38, 40, 34, 35, and 39 of the Teacher Professionalism Inventory - Self each received 123 responses (or 93.2\%) or higher that indicated teachers somewhat agreed, agreed, or strongly agreed with the statements provided. Item 43 received the highest number of responses at $131(99.2 \%)$ indicating some degree of agreement that teachers remain receptive to new ideas and change. Items 37, 41, 44, 42, and 36 saw a decline in teachers' agreement regarding the statements pertaining to commitment to change and continuous improvement. In regards to item $42,36.60 \%$ of teachers disagreed that they regularly observed other teachers to improve their own teaching. Furthermore, $47.70 \%$ of teachers responded that they disagreed with statement 36 , indicating they that they do not make presentations at seminars, workshops, and/or conferences. While responses indicated that commitment to change and continuous improvement received the lowest mean score, 4.59 , of the subscales pertaining to teacher professionalism, the data indicates that overall teacher's perceive themselves as individuals who strongly agree with a majority of the statements included. 
Table 5

Commitment to Change and Continuous Improvement in Ascending Order Agreement as Self-Reported by Teachers

\begin{tabular}{|c|c|c|c|c|c|}
\hline \multirow{2}{*}{ Item } & \multirow{2}{*}{$\begin{array}{l}\text { Professionalism Statement } \\
\text { I make presentations at seminars, workshops, } \\
\text { and/or conferences. }\end{array}$} & \multicolumn{2}{|c|}{ Disagreement } & \multicolumn{2}{|c|}{ Agreement } \\
\hline & & 63 & $47.70 \%$ & 69 & $52.30 \%$ \\
\hline 42 & $\begin{array}{l}\text { I regularly observe other teachers to improve } \\
\text { my own teaching. }\end{array}$ & 47 & $35.60 \%$ & 85 & $64.40 \%$ \\
\hline 44 & $\begin{array}{l}\text { I engage in teacher research or action } \\
\text { research to improve my own practice. }\end{array}$ & 30 & $22.70 \%$ & 102 & $77.30 \%$ \\
\hline 41 & $\begin{array}{l}\text { I keep up with current social and political } \\
\text { trends affecting education. }\end{array}$ & 16 & $12.10 \%$ & 116 & $87.90 \%$ \\
\hline 37 & $\begin{array}{l}\text { I am willing to lead a new team in my school } \\
\text { setting to address areas of student need }\end{array}$ & 14 & $10.60 \%$ & 118 & $89.40 \%$ \\
\hline 35 & $\begin{array}{l}\text { I am dedicated to teaching as a life-long } \\
\text { career. }\end{array}$ & 9 & $6.80 \%$ & 123 & $93.20 \%$ \\
\hline 39 & $\begin{array}{l}\text { I actively seek professional development } \\
\text { opportunities. }\end{array}$ & 9 & $6.80 \%$ & 123 & $93.20 \%$ \\
\hline 34 & $\begin{array}{l}\text { I select teaching strategies based on best } \\
\text { practices in education and current research } \\
\text { findings. }\end{array}$ & 6 & $4.50 \%$ & 126 & $95.50 \%$ \\
\hline 40 & $\begin{array}{l}\text { I experiment with innovative teaching } \\
\text { practices. }\end{array}$ & 5 & $3.80 \%$ & 127 & $96.20 \%$ \\
\hline 38 & $\begin{array}{l}\text { I contribute to the professional growth of my } \\
\text { colleagues. }\end{array}$ & 4 & $3.00 \%$ & 128 & $97.00 \%$ \\
\hline 43 & I remain receptive to new ideas and change. & 1 & $0.80 \%$ & 131 & $99.20 \%$ \\
\hline
\end{tabular}

Note. Possible scores from 1-6 (0-3 = Disagreement and 4-6 = Agreement; no Neutral point was provided in order to ensure a positive or a negative response; Table is sorted in ascending order utilizing the degrees of agreement 4-6).

Beyond the Classroom. Eleven six-point Likert scale responses were provided teachers, varying from strongly disagree to strongly agree, with no provision for a neutral response. Represented by a mean score of 5.13 , respondents indicated a majority agreed with the statements provided to some varying degree concerning the subscale of items 
pertaining to going beyond the classroom. Table 6 articulates the statements utilized to gather data for "Beyond the Classroom." An item analysis representing both ranges of agreement, strongly disagree to somewhat disagree (0-3) and somewhat agree to strongly agree (4-6) are presented along with the percentage of response rate pertaining to each. For the purpose of this data analysis the researcher utilized the degree of agreement (4-6) and sorted the items in ascending order from the highest response to the lowest.

All responses gathered pertaining to items 58, 54, 59, and 60 demonstrated some degree of agreement. All teachers perceived themselves as: cooperating with colleagues in the best interest of students, serving as positive role models for students and colleagues, showing respect, and foster a positive work environment. A majority of teachers agreed with items, 56, 57, 62, and 61. Indicating that they: shared teaching strategies and ideas with colleagues, established friendly and cooperative relationships with parents, had a willingness to mentor new and veteran teachers, and discussed teaching philosophies with colleagues. Items 64, 55, and 63 declined in teachers' degree of agreement, indicating that some did not: participate actively in curriculum development, actively participate in school wide committees and/or school decision making, and stay actively involved in professional organizations. 
Table 6

Beyond the Classroom in Ascending Order by Agreement as Self-Reported by Teachers

\begin{tabular}{|c|c|c|c|c|c|}
\hline \multirow{2}{*}{ Item } & \multirow{2}{*}{$\begin{array}{l}\text { Professionalism Statement } \\
\text { I stay actively involved in professional } \\
\text { organizations for educators }\end{array}$} & \multicolumn{2}{|c|}{ Disagreement } & \multicolumn{2}{|c|}{ Agreement } \\
\hline & & 26 & $19.70 \%$ & 106 & $80.30 \%$ \\
\hline 55 & $\begin{array}{l}\text { I actively participate on school-wide } \\
\text { committees and/or in school decision } \\
\text { making }\end{array}$ & 20 & $15.20 \%$ & 112 & $84.80 \%$ \\
\hline 64 & I participate in curriculum development & 18 & $13.60 \%$ & 114 & $86.40 \%$ \\
\hline 61 & $\begin{array}{l}\text { I discuss teaching philosophies with } \\
\text { colleagues }\end{array}$ & 8 & $6.10 \%$ & 124 & $93.90 \%$ \\
\hline 62 & $\begin{array}{l}\text { I mentor or am willing to mentor } \\
\text { beginning and experienced teachers }\end{array}$ & 5 & $3.80 \%$ & 127 & $96.20 \%$ \\
\hline 57 & $\begin{array}{l}\text { I establish friendly and cooperative } \\
\text { relationships with parents }\end{array}$ & 4 & $3.00 \%$ & 128 & $97.00 \%$ \\
\hline 56 & $\begin{array}{l}\text { I share teaching strategies and ideas } \\
\text { with colleagues }\end{array}$ & 2 & $1.50 \%$ & 130 & $98.50 \%$ \\
\hline 58 & $\begin{array}{l}\text { I cooperate with colleagues in the } \\
\text { interest of students }\end{array}$ & 0 & $0.00 \%$ & 132 & $100.00 \%$ \\
\hline 54 & $\begin{array}{l}\text { I serve as a positive role model for } \\
\text { students and colleagues }\end{array}$ & 0 & $0.00 \%$ & 132 & $100.00 \%$ \\
\hline 59 & $\begin{array}{l}\text { I show respect for colleagues and } \\
\text { administrators }\end{array}$ & 0 & $0.00 \%$ & 132 & $100.00 \%$ \\
\hline 60 & $\begin{array}{l}\text { I help foster a positive working } \\
\text { environment within the school }\end{array}$ & 0 & $0.00 \%$ & 132 & $100.00 \%$ \\
\hline
\end{tabular}

Note. Possible scores from 1-6 (0-3 = Disagreement and 4-6 = Agreement; no Neutral point was provided in order to ensure a positive or a negative response; Table is sorted in ascending order utilizing the degrees of agreement 4-6). 
Subject and Pedagogical Knowledge. Nine six-point Likert scale responses were provided teachers, varying from strongly disagree to strongly agree, with no provision for a neutral response. Represented by a mean score of 5.23, respondents indicated a majority agreed with the statements provided to some varying degree. An item analysis representing both ranges of agreement, strongly disagree to somewhat disagree (0-3) and somewhat agree to strongly agree (4-6) are presented along with the percentage of response rate pertaining to each. For the purpose of this data analysis the researcher utilized the degree of agreement (4-6) and sorted the items in ascending order from the highest response to the lowest.

All items representing Subject and Pedagogical Knowledge received a strong response rate indicating some degree of agreement. Item 49 indicated that $4.5 \%$ of teachers disagreed that they possessed a high degree of pedagogical knowledge. Item 48 revealed that $6.8 \%$ of teachers disagreed to some degree that they knew and applied human development and learning theories. With a mean score of 5.23, teachers selfperceived that they possessed, to some degree, subject and pedagogical knowledge and believed it to be an important component to their self-perception of professionalism. Table 7 articulates the statements utilized to gather data for "Subject and Pedagogical Knowledge." 
Table 7

Subject and Pedagogical Knowledge in Ascending Order by Agreement as Self-Reported by Teachers

\begin{tabular}{|c|c|c|c|c|c|}
\hline Item & Professionalism Statement & \multicolumn{2}{|c|}{ Disagreement } & \multicolumn{2}{|c|}{ Agreement } \\
\hline 48 & $\begin{array}{l}\text { I know and apply human development } \\
\text { and learning theories }\end{array}$ & 9 & $6.80 \%$ & 123 & $93.20 \%$ \\
\hline 51 & $\begin{array}{l}\text { I possess a high degree of pedagogical } \\
\text { knowledge }\end{array}$ & 6 & $4.50 \%$ & 126 & $94.50 \%$ \\
\hline 49 & $\begin{array}{l}\text { I regularly evaluate my own choices } \\
\text { and actions in the classroom }\end{array}$ & 2 & $1.50 \%$ & 130 & $98.50 \%$ \\
\hline 46 & $\begin{array}{l}\text { I understand the developmental needs } \\
\text { of children }\end{array}$ & 1 & $0.80 \%$ & 131 & $99.20 \%$ \\
\hline 47 & $\begin{array}{l}\text { I make classroom decisions based on } \\
\text { the needs of students }\end{array}$ & 1 & $0.80 \%$ & 131 & $99.20 \%$ \\
\hline 52 & $\begin{array}{l}\text { I consider all aspects of the students I } \\
\text { teach }\end{array}$ & 1 & $0.80 \%$ & 131 & $99.20 \%$ \\
\hline 53 & $\begin{array}{l}\text { I create a positive learning environment } \\
\text { for students }\end{array}$ & 1 & $0.80 \%$ & 131 & $99.20 \%$ \\
\hline 45 & $\begin{array}{l}\text { I teach in developmentally appropriate } \\
\text { ways }\end{array}$ & 0 & $0.00 \%$ & 132 & $100.00 \%$ \\
\hline 50 & $\begin{array}{l}\text { I possess a high degree of content } \\
\text { knowledge in my areas of certification }\end{array}$ & 0 & $0.00 \%$ & 132 & $100.00 \%$ \\
\hline
\end{tabular}

Note. Possible scores from 1-6 (0-3 = Disagreement and 4-6 = Agreement; no Neutral point was provided in order to ensure a positive or a negative response; Table is sorted in ascending order utilizing the degrees of agreement 4-6).

Personal Characteristics. Twelve six-point Likert scale responses were provided teachers, varying from strongly disagree to strongly agree, with no provision for a neutral response. Represented by a mean score of 5.43, respondents indicated the strongest frequency and percentage of agreement regarding the statements addressing Personal Characteristics. Of the 132 valid responses none of the teachers disagreed with the statements provided. All 132 teachers agreed with the statements provided. An item analysis articulating the frequency and percentage of responses pertaining to each item is provided. 
With a mean score of 5.43, Personal Characteristics is perceived by teachers as one of the most important subscales pertaining to professionalism. Items $23,25,28,29$, 31 , and 32 indicated that all teachers' to some degree of agreement perceived themselves as possessing personal character as it pertains to professionalism. While items $24,26,33$, 27, 22, and 30 deviated slightly as few teacher did not agree with the items, the overall impression gained is that teachers self-perceive that personal character is an important part of their perceived professionalism. Table 8 articulates the statements utilized to gather data for Personal Characteristics.

Table 8

Personal Characteristics in Ascending Order by Agreement as Self-Reported by Teachers

\begin{tabular}{|c|c|c|c|c|c|}
\hline \multirow{2}{*}{$\begin{array}{c}\text { Item } \\
22\end{array}$} & \multirow{2}{*}{$\begin{array}{l}\text { Professionalism Statement: Personal } \\
\text { Character } \\
\text { It is important to me to dress in a neat } \\
\text { manner }\end{array}$} & \multicolumn{2}{|c|}{ Disagreement } & \multicolumn{2}{|c|}{ Agreement } \\
\hline & & 3 & $2.20 \%$ & 129 & $97.80 \%$ \\
\hline 30 & $\begin{array}{l}\text { I look forward to coming to school each } \\
\text { day }\end{array}$ & 3 & $2.30 \%$ & 129 & $97.70 \%$ \\
\hline 27 & $\begin{array}{l}\text { I regard the education of students as my } \\
\text { primary duty }\end{array}$ & 2 & $1.50 \%$ & 130 & $98.50 \%$ \\
\hline 24 & $\begin{array}{l}\text { I put the welfare of students before } \\
\text { personal interests }\end{array}$ & 1 & $0.80 \%$ & 131 & $99.20 \%$ \\
\hline 26 & $\begin{array}{l}\text { I behave in an ethical manner in and out of } \\
\text { school }\end{array}$ & 1 & $0.80 \%$ & 131 & $99.20 \%$ \\
\hline 33 & $\begin{array}{l}\text { I maintain composure in all school-related } \\
\text { situations }\end{array}$ & 1 & $0.80 \%$ & 131 & $99.20 \%$ \\
\hline 23 & $\begin{array}{l}\text { I exhibit confidence in my teaching on a } \\
\text { daily basis }\end{array}$ & 0 & $0.00 \%$ & 132 & $100.00 \%$ \\
\hline 25 & I display enthusiasm for teaching & 0 & $0.00 \%$ & 132 & $100.00 \%$ \\
\hline 28 & I see myself as a life-long learner & 0 & $0.00 \%$ & 132 & $100.00 \%$ \\
\hline 29 & I respect students and their ideas & 0 & $0.00 \%$ & 132 & $100.00 \%$ \\
\hline 31 & $\begin{array}{l}\text { I exhibit personal responsibility for the } \\
\text { quality of my own teaching }\end{array}$ & 0 & $0.00 \%$ & 132 & $100.00 \%$ \\
\hline 32 & I set high standards for self and students & 0 & $0.00 \%$ & 132 & $100.00 \%$ \\
\hline
\end{tabular}




\section{Summary for Research Question Two}

Quantitative data was collected to address research question two, "how do secondary teachers view themselves as professionals?" Four subscales of professionalism were utilized as identified by Tichenor and Tichenor (2005), Cheng (1996), and Socket (1993). Using a six-point Likert scale means of response, teachers responded to each statement, varying from strongly disagree to strongly agree with no neutral point.

In analyzing the teachers' responses, teachers perceived themselves as individuals who participated in, or possessed, to some degree, the characteristics necessary to be a professional: (a) Commitment to Change and Continuous Improvement, (b) Beyond the Classroom, (c) Subject and Pedagogical Knowledge, and (d) Personal Characteristics. Teachers' responses to the items emphasizing Commitment to Change and Continuous Improvement revealed that while a majority of respondents agreed to some degree that they perceived themselves as possessing or demonstrating such characteristics, there was still a small percentage of teachers who did not agree. For instance, $47.7 \%$ of respondents indicated that they did not make presentations at seminars, workshops, and/or conferences (item 36).

Teachers' self-perception of their inclusion/participation in activities that go Beyond the Classroom is another important subscale of professionalisms. Respondents felt, to some degree of agreement, they participated in activities that afforded them the opportunity to impact others beyond just their students. Teachers' indicated they shared teaching practices with colleagues, cooperated with colleagues when considering what is in the best interest of the student, showing respect, and fostering a positive work 
environment. Some teachers indicated they did not participate in school decisionmaking, curriculum development, and were not involved in professional organizations. While the teachers indicating disagreement is small, the data indicates an overall agreement that teachers self-perceive themselves as individuals who incorporate components of going beyond the classroom that enhanced their professionalism.

Items addressing Subject and Pedagogical Knowledge received a strong response rate from teachers that indicated a strong degree of agreement pertaining to the professionalism statements. Data indicated that all participating teachers perceived themselves as teaching in developmentally appropriate ways and possessing a high degree of content knowledge in areas of certification. With a combined mean of 5.23, teachers self-perceived that subject and pedagogical knowledge is important to the professional position held by teachers.

The subscale of professionalism that emphasized Personal Characteristics revealed that teachers believed personal character to be of great value and self-perceived that they incorporates such in their daily practice as an educator. Receiving a mean score of 5.43, a majority of teachers demonstrated that Personal Characteristics is important and an important component to what it means to be a professional. A small percentage of teachers expressed that they did not look forward to coming to school each day, and didn't feel that it was important to dress in a neat manner.

Figure 8 provides a graphic representation of teachers' responses with the mean provided for the four subscales that summarize professionalism: (a) Commitment to Change, (b) Beyond the Classroom, (c) Subject and Pedagogical Knowledge, and (d)

\section{Personal Character.}



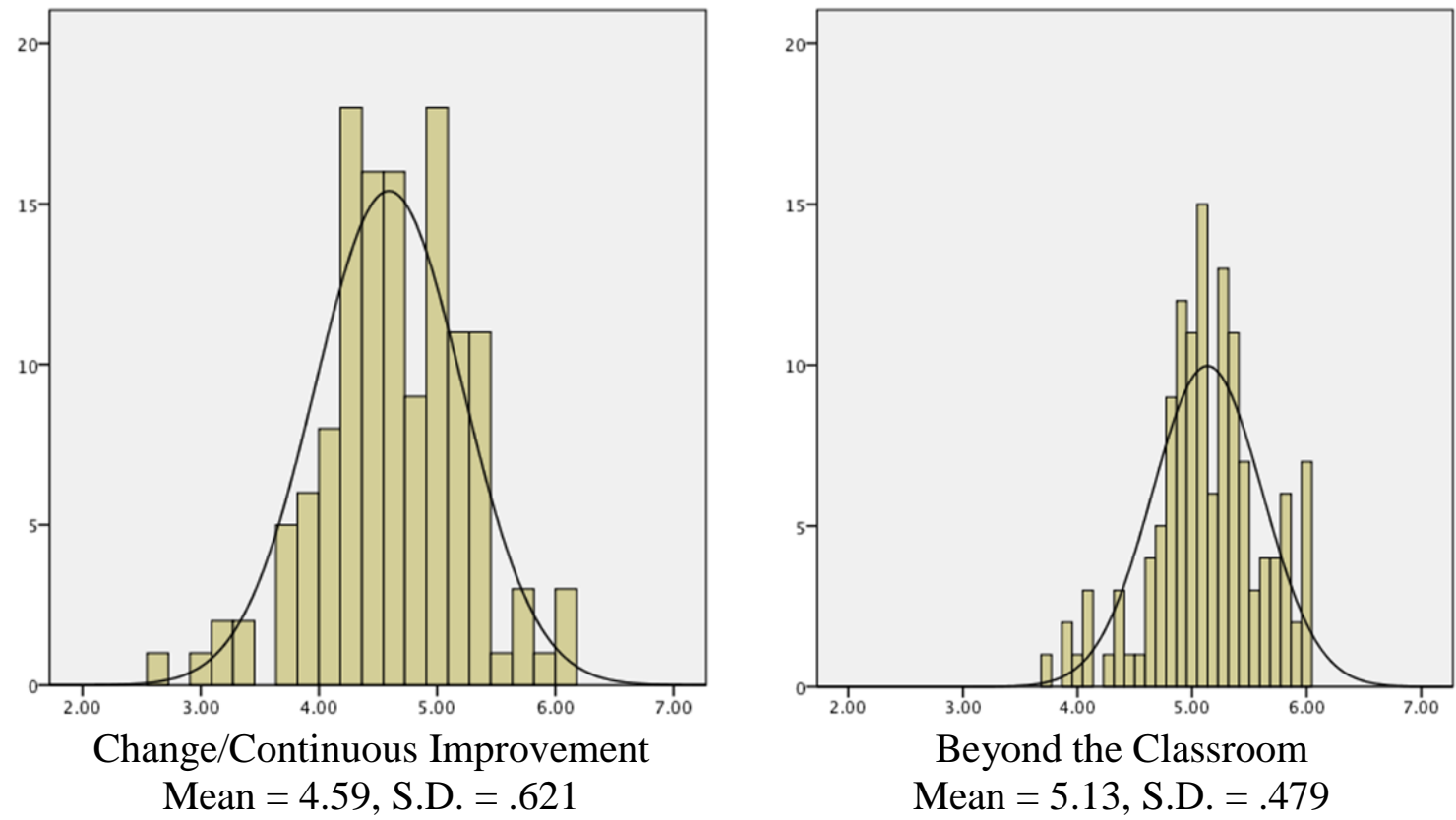

Beyond the Classroom

Mean $=5.13$, S.D. $=.479$
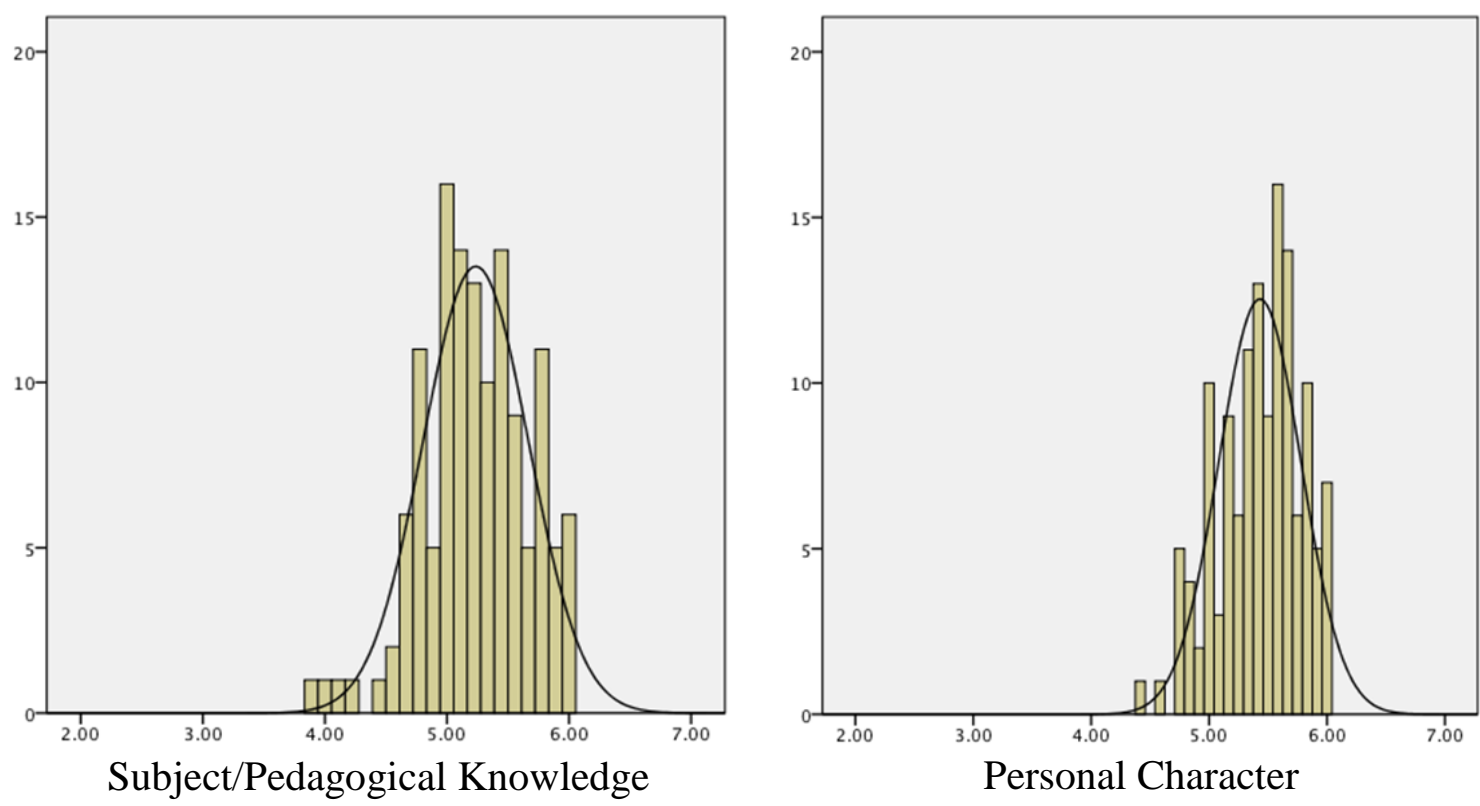

Mean $=5.24$, S.D. $=.433$

Mean $=5.43$, S.D. $=.349$

Figure 8. Self-Perception of Professionalism Response Results 


\section{Results for Research Question Three}

The following data analysis provided findings addressing research question three. "What is the relationship between the teachers' perception of the principal's use of power and their self-perceptions of professionalism?" Research question three contained two sub-questions to provide for a correlational analysis: (a) what base of power used by principals is directly related to teachers' self-perception of professionalism; and (b) What base of power used by principals is inversely related to teachers' self-perception of professionalism?

Once the data was analyzed using SPSS, a Pearson's Correlation Coefficient with a significance level of .05 was used to examine the relationship between the principal's use of power and the teachers' self-perception of professionalism. For the purpose of this study the researcher further identified correlations of $+/-.1$ as variables having a small effect on each other.

\section{Overview of Correlations}

Negative correlations were identified as having an inverse relationship existent between power and professionalism while positive correlations were identified as having a direct relationship existent between power and professionalism. While no relationship between power bases and professionalism subscales were identified as being statistically significant, several relationships existent between the base of power and the professionalism subscales were identified as having a small effect $(+/-.1)$ on each other. Table 9 provides an overview of the correlations discovered when analyzing the relationship the principal's use of power and the teachers' self-perception of professionalism. 
Table 9

Correlations: Power and Professionalism

\begin{tabular}{lcccc}
\hline & $\begin{array}{c}\text { Commitment } \\
\text { Cersonal } \\
\text { Character }\end{array}$ & $\begin{array}{c}\text { Change } \\
\text { And } \\
\text { Continuous } \\
\text { Improvement }\end{array}$ & $\begin{array}{c}\text { Subject } \\
\text { Knowledge }\end{array}$ & $\begin{array}{c}\text { Beyond the } \\
\text { Classroom }\end{array}$ \\
\hline Coercive Power & $\mathbf{- . 1 1 5}$ & -.079 & $\mathbf{- . 1 2 3}$ & $\mathbf{- . 1 6 8}$ \\
Connection Power & -.038 & .087 & $\mathbf{- . 1 2 0}$ & -.083 \\
Expert Power & .090 & -.002 & $\mathbf{. 1 6 3}$ & .074 \\
Information Power & -.022 & $\mathbf{. 1 1 2}$ & .055 & $\mathbf{. 1 4 0}$ \\
Legitimate Power & -.033 & $\mathbf{- . 1 3 0}$ & -.033 & -.004 \\
Referent Power & $\mathbf{. 1 5 5}$ & $\mathbf{- . 0 4 4}$ & $\mathbf{. 1 5 6}$ & $\mathbf{. 1 4 9}$ \\
Reward Power & -.017 & $\mathbf{. 1 4 3}$ & -.077 & -.049 \\
\hline
\end{tabular}

Note. No relationships were statistically significant. All relationships identified in this table as having a small effect of $+/-.1$ have been bolded.

\section{Direct Relationship with Professionalism: RQ3a}

Four bases of power were identified as being directly related to teachers' selfperception of professionalism; (a) Expert Power, (b) Information Power, (c) Referent Power, and (d) Reward Power. Teachers experienced higher levels of professionalism in Subject Knowledge when they perceived their principals to be utilizing Expert Power. Commitment to Change and Continuous Improvement, as well as the teacher's willingness to go Beyond the Classroom increased when they perceived their principals to be utilizing Information Power. Teacher's experienced higher levels of professionalism in Personal Characteristics, Subject Knowledge, and willingness to go Beyond the Classroom with the principals increased use of Referent Power. Finally, the principals' use of Reward Power revealed an increase in teacher's professionalism in their 
Commitment to Change and Continuous Improvement. Table 10 provides a summary of the power bases that are directly related to the teachers' self-perception of professionalism.

\section{Inverse Relationship with Professionalism: RQ3b}

Three bases of power were identified as being inversely related to teachers' selfperception of professionalism; (a) Coercive Power, (b) Legitimate Power, and (c) Connection Power. Teachers experienced lower levels of professionalism in Personal Characteristics, Subject Knowledge, and going Beyond the Classroom when principals' were perceived to be utilizing Coercive Power. When the principals' use of Legitimate Power was perceived by teachers, a lower level of professionalism concerning their Commitment to Change and Continuous Improvement was noticed. Finally, the principals' use of Connection Power revealed an inverse relationship with the teachers' self-perception of professionalism as it pertained to Subject Knowledge. Table 10 provides a summary of the power bases that are inversely related to the teachers' selfperception of professionalism. 
Table 10

Direct and Inverse Correlations

\begin{tabular}{lcccc}
\hline & $\begin{array}{c}\text { Commitment } \\
\text { Personal } \\
\text { Character }\end{array}$ & $\begin{array}{c}\text { Change } \\
\text { And } \\
\text { Continuous } \\
\text { Improvement }\end{array}$ & $\begin{array}{c}\text { Subject } \\
\text { Knowledge }\end{array}$ & $\begin{array}{c}\text { Beyond the } \\
\text { Classroom }\end{array}$ \\
\hline Coercive Power & Inverse & ---- & Inverse & Inverse \\
Connection Power & ---- & ---- & Inverse & ---- \\
Expert Power & ---- & ---- & Direct & ---- \\
Information Power & ---- & Direct & ---- & Direct \\
Legitimate Power & ---- & Inverse & ---- & ---- \\
Referent Power & Direct & ---- & Direct & Direct \\
Reward Power & ---- & Direct & ---- & ---- \\
\hline
\end{tabular}

Note. No relationships were statistically significant. All relationships identified in this table were small +/-.1.

\section{Summary for Research Questions Three}

Quantitative data were collected to answer question three, "What is the relationships between the teachers' perception of the principal's use of power and selfperception of professionalism?" Research question three contained two sub-questions “(a) What base of power used by principals directly related to teachers' self-perception of professionalism, and (b) What base of power used by principals is inversely related to teachers' self-perception of professionalism?"

An analysis utilizing Pearson Correlation Coefficient was conducted with a significance level of .5. When examining the correlation between the bases of power and the subscales of professionalism, (a) Commitment to Change and Continuous 
Improvement, (b) Beyond the Classroom, (c) Subject/Pedagogy Knowledge, (d) and Personal Characteristics, no statistically significant correlations were found. Due to no evidence of a statistically significant relationship existing between the principal's use of power and the teachers' self-perception of professionalism it was decided not to proceed with completing the forward multiple-regression resulting in constructing a prediction model. However, when utilizing the significance level of $+/-.1$ several small effects were identified. Teacher's experienced higher levels of professionalism when principals utilized, (a) Expert Power, (b) Information Power, (c) Referent Power, and (d) Reward Power. Teacher's experienced lower levels of professionalism when leadership utilized, (a) Coercive Power, (b) Connection Power, and (c) Legitimate Power.

\section{Summary}

Throughout this chapter, a data analysis addressing the research questions has been provided. The purpose was to explore the relationship between the principals' use of power and the teacher's self-perception of professionalism. A quantitative methods approach was used for gathering data. A survey utilizing 21-forced choice pair responses combined with 43 Liker scale responses was completed by 132 out of 925 certified high school teachers. Chapter five provides a detailed summary and discusses suggestions for future research opportunities.

\section{Research Question One}

Research question one, “As perceived by teachers, how do secondary principals use power?" was answered utilizing 21 forced-choice-pair response items. Seven bases of power were explored: (a) Connection Power, (b) Coercive Power, (c) Reward Power, (e) Referent Power, (f) Information Power, (g) Legitimate Power, and (h) Expert Power. 
The quantitative survey resulted in teachers perceiving that their principal's utilized expert power, legitimate power, and information power.

\section{Research Question Two}

Research questions two, "How do secondary teachers view themselves as professionals?" was answered using a quantitative Likert response survey. Four subscales of professionalism were explored, (a) Commitment to Change and Continuous Improvement, (b) Beyond the Classroom, (c) Subject/Pedagogical Knowledge, and (d) Personal Characteristics. Each subscale provided data exploring teacher's selfperception of professionalism.

\section{Research Question Three}

Research question three, "What is the relationship between the teachers' perception of the principal's use of power and their self-perception of professionalism?" was addressed using two sub questions, (a) What base of power used by principals is directly related to teachers' self-perception of professionalism? And (b) What base of power used by principals is inversely related to teachers' self-perception of professionalism? An analysis utilizing the Pearson correlation coefficient yielded no statistically significant relationships between the power bases or the subscales of professionalism. 


\section{CHAPTER FIVE \\ DISCUSSION OF FINDINGS}

\section{Introduction}

With the dawn of the human resource theory in the early 1900's through the work of Taylor (1916) and Mayo (1933), and further developed by McGregor (1960), educational leaders began to take stock in how they interacted with their teachers. The premise that people existed to serve and meet the needs of the organization dwindled and the understanding that organizations existed to serve and meet the needs of people (Bolman \& Deal, 2008) became operationalized in how organizational leaders interacted with subordinates. While the educational arenas predominate focus is to serve and meet the needs of students, it also exists to serve and meet the needs of the teacher professionals.

Principals have the challenging task of fostering an environment that meets state certification requirements and goals of nurturing student growth, while at the same time fostering an environment where teachers feel supported and valued as professionals. Principals can and do, at times, impose upon teachers programs, committees, curricular implementations, and agendas on teachers, disregarding how such impositions will impact the teachers. Principals can often times make these decisions because they believe them to be what is best for the students, while at the same time disregarding how such impositions will impact teachers sense of professionalism. 


\section{Overview of the Study}

The purpose of this study was to examine the relationship between the principal's use of power and the teachers' self-perception of professionalism. The research questions utilized for this study were constructed utilizing (a) teachers' perceptions of the principal's use of power, (b) teachers' self-perception of professionalism, and (c) the relationship between the teacher's perception of the principal's use of power and their self-perception of professionalism. A quantitative approach was used to gather data relevant to the research questions.

Findings from the data gathered provided limited insight into how teachers perceived their principal's use of power and their self-perception of professionalism. In this study, survey data was collected from certified secondary teachers of high schools located within the Central Ozark Conference (COC) in Missouri State. An online survey containing two inventories, (a) power perception profile, and (b) teacher's self-perception of professionalism inventory, were distributed electronically. A total of 925 certified high school teachers were identified and received the survey with 132 completing the survey, resulting in a fourteen percent response rate. The two inventories were combined together to create the Power and Professionalism Inventory and asked teachers to provide responses pertaining to their perceptions of their principals use of power and their own self-perceptions of professionalism.

The research examined if a relationship could be determined to exist between the teachers' perception of their principal's use of power and the teacher's self-perception of professionalism. Data collected was analyzed quantitatively and examined teachers' perceptions of their principal's use of power through analysis of means in ascending 
order. The study then examined the teachers' self-perception of professionalism through analysis of means in ascending order. The responses from both inventories were then analyzed utilizing Pearson Correlation Coefficient with a significance level of .05. The responses from the survey were collected to examine if a connection existed between the principal's use of power and the teachers' self-perception of professionalism.

\section{Research Questions}

The following research questioned were used to drive the quantitative research project, “The Relationship Between the Principal's Use of Power and the Teachers' SelfPerception of Professionalism:"

1. As perceived by teachers, how do secondary principals use power?

2. How do secondary teachers view themselves as professionals?

3. What is the relationships between the teachers' perception of the principal's use of power and their self-perceptions of professionalism?

a. What base of power used by principals is directly related to teachers' selfperception of professionalism?

b. What base of power used by principals is inversely related to teachers' self-perception of professionalism?

\section{Summary of Findings}

\section{Descriptive Results}

The proceeding sections present the findings of the 132 teacher respondents who participated in this study. The sections are organized by sample demographics, Principal's use of power and teacher professionalism. Furthermore, the research questions used to frame this study are summarized in relation to data gathered. 


\section{Sample Demographics}

The quantitative study examined the relationship between the principal's use of power and the teachers' self-perception of professionalism. A convenience means of selecting the sample was used. The population of certified secondary teachers numbered approximately 20,050. From that population high schools that were part of the Central Ozark Conference (COC) were selected to participate in the study. The COC consisted of 15 public high schools that included approximately 1,276 teachers. Of the 15 high schools 10 agreed to participate. A total of 925 certified high school teachers received the survey, of which 132 valid responses were received.

\section{Principal's Use of Power}

The principal's use of power was examined utilizing an adaptation of The Power Perception Profile - Perception of Other as developed by Hersey, Blanchard, and Natemeyer (1988). The survey was comprised of 21-forced choice pair responses that required the teacher to allocate a total point distribution of three between both choices, resulting in a distribution that validated which of the seven power bases the teacher perceived his/her principal to utilize the most.

\section{Professionalism}

The survey Teacher Professionalism Inventory - Self comprised of forty-three questions was presented utilizing a six point Likert-scale ranging from strongly disagree to strongly agree. The professionalism inventory consisted of four subscales: (a)

Personal Characteristics, (b) Commitment to Change and Continuous Improvement, (c) Subject/Pedagogical Knowledge, and (d) Beyond the Classroom. 


\section{Research Question One}

The principals' use of power as perceived by teachers was calculated by The Power Perception Profile - Perception of Other as developed by Hersey, Blanchard, and Natemeyer (1988). The seven bases of power examined included: (a) Coercive Power, (b) Connection Power, (c) Expert Power, (d) Information Power, (e) Legitimate Power, (f) Referent Power, and (g) Reward Power. The point distribution indicated which base of power the respondent perceived their principal to utilize the most.

Findings from the survey indicated that connection power, coercive power, and reward power were the power bases utilized least by principals as perceived by teachers. Furthermore, information power, legitimate power and expert power were perceived by teachers to be greatly utilized by principals.

\section{Research Question Two}

The teachers' self-perception of professionalism was calculated through the use of the Teacher Professionalism Inventory - Self, developed utilizing the work of Tichenor and Tichenor (2005), Cheng (1996), and Socket (1993). Professionalism was categorized as encompassing four dimensions: (a) Personal Characteristics, (b) Commitment to Change and Continuous Improvement, (c) Subject and Pedagogical Knowledge, and (d) participation in educational activities Beyond the Classroom.

The findings from this study suggested that teachers view themselves to be professionals in relation to the four dimension of professionalism with exception of a few components. In regards to teacher's commitment to change and continuous improvement, while respondents generally agreed, there were components that were lacking. For instance, teacher's making presentations at seminars, workshops, and/or 
conferences were limited. Furthermore, having the opportunity to regularly observe other teachers to improve their own teaching was another component that was lacking.

The findings also suggested that teachers strongly agreed that their reach Beyond the Classroom added greatly to their self-perception of professionalism. Teachers believed they served as positive role models for students and colleagues, established friendly and cooperative relationships with parents, and expressed a willingness to mentor beginning and experienced teachers. Two areas that were lacking for some teachers were being active participants on school-wide committees and/or in school decision making, and being involved in professional organizations for educators.

The final two dimensions of professionalism, Subject and Pedagogical Knowledge, and Personal Characteristics received strong response rates in regards to how teachers self-perceived these components to be a part of their identification with professionalism. Teachers perceived themselves to be individuals who incorporated, practiced, and involved the dimensions of professionalism to some degree.

\section{Research Question Three}

The relationship between the teachers' perception of the principal's use of power and their self-perception of professionalism was analyzed utilizing Pearson's correlation coefficient with .5 level of significance utilized. While evidence of statistical significance was difficult to establish concerning the relationships between the principal's use of power and the teachers' self-perception of professionalism there were several relationships were identified as having a direct effect and an inverse effect. This researcher utilized the significance level of $+/-.1$ to identify both positive and negative 
correlations that existed between the principals' use of power and the teacher's selfperception of professionalism.

When the principals' use of Expert Power, Information Power, Referent Power, and Reward Power increased, a direct relationship between the principal's use of power and the teacher's self-perception of professionalism was identified. When the principals' use of Coercive Power, Connection Power, and Legitimate Power increased, an inverse relationship between the principals' use of power and teacher's self-perception of power

was identified. While neither the direct or inverse relationships revealed a relationships of statistical significance, they did reveal that a small relationship was existent between the principals' use of power and the teacher's self-perception of professionalism.

\section{Discussion}

This quantitative study was developed to examine the relationship between the principals' use of power and teacher's self-perception of professionalism. The relationship existent between the teacher and the principal was informed by the LeaderMember Exchange Theory (Northouse, 2010) and Theory X and Theory Y (McGregor, 1960). Utilizing both theories this researcher set out to examine the principal and the teacher in relation to how the principals' use of power impacted the teacher's selfperception of professionalism.

While studies examining the relationships between the principals' use of power and the teacher's self-perception of professionalism are extremely limited, Willower (1960) conducted a study entitled Professionalization and Education. The study existed as one of the most historically significant studies in regards to exploring the educator's 
sense of job satisfaction and the impact that school leaders have in fulfilling educators' professional goals.

Willower (1960) regarded the teacher professional as an individual who had a positive regard for his or her superior if they "held flexible and indefinite expectations for the subordinates' role" (p. 75). In a time with heightened accountability and standards for educators, such autonomy provided to teachers prevails as being limited. However, the principals' impact on teacher's self-perception of professionalism resides as a topic of continued interest of scholars, educational leaders, and teachers.

The survey tool for this study was distributed to approximately 925 certified secondary teachers. Of the 925 surveys distributed 132 completed responses were received. Teacher's responses concerning their perceptions of their principals' use of power as well as their self-perception of their own professionalism provided both positive and negative correlations. Several positive correlations between the principals' use of power and the teacher's self-perception of professionalism were identified.

Teachers experienced higher levels of professionalism where principals' were perceived to use Expert Power, Information Power, Referent Power, and Reward Power. Teachers who perceived their principal to use Expert Power revealed a direct relationship with the Subject and Pedagogical Knowledge professionalism subscale. Those who perceived Information Power to be the power base utilized by their principal revealed a direct relationship with Commitment to Change and Continuous Improvement and being involved in activities Beyond the Classroom. Teachers who perceived their principal to utilize Reward Power demonstrated an increase in their Commitment to Change and Continuous Improvement. Finally, Teachers who self-perceived their principal's to use 
Referent Power had the greatest self-perception of professionalism, identifying a direct correlation with Personal Characteristics, Subject and Pedagogical Knowledge, and being involved in activities Beyond the Classroom. While several positive correlations were discovered so were those that had an inverse effect.

Teachers experienced lower levels of professionalism when their principals' utilized Coercive Power, Connection Power, and Legitimate Power. Those who perceived their principal to use Connection Power revealed an inverse relationships with Subject and Pedagogical Knowledge, while the principals' use of Legitimate Power revealed an inverse relationship with Commitment to Change and Continuous Improvement. The use of Coercive Power demonstrated the greatest inverse relationship, impacting Personal Characteristics, Subject and Pedagogical Knowledge, and participation in activities that went Beyond the Classroom.

Overall, teachers' in the Central Ozark Conference who completed the survey tool communicated an overall positive sense of professionalism and regarded their principals' in a positive way concerning their demonstrated use of power. Teachers' indicated that they were generally supported and perceived themselves as professionals in regards to the four dimensions of professionalisms explored: (a) Personal Characteristics, (b) Commitment to Change and Continuous Improvement, (c) Subject and Pedagogical Knowledge, and (d) participation in educational activities Beyond the Classroom.

\section{Implication for Practice}

Educational leaders have the role and responsibility of ensuring that their organizations create opportunities for growth, not only for the student but for the teacher as well. The results of this study provided insight from the teacher's perception of how a 
principals' use of power can impact the teacher's self-perception of professionalism. By exploring the principals' use of power as perceived by the teacher combined with the teacher's self-perception of professionalism the relationships between power and professionalism were able to be better understood.

While the limited response rate existed as a limitation concerning identifying statistically significant relationships existent between the principals' use of power and teacher's self-perception of professionalism, several small effects were identified that could provide guidance for principals' use of power as well as future training of school leaders. Through examining how the teacher's self-perception of professionalism was impacted by the perceived use of power by the principal, leaders can begin to substantially impact the professional culture of their organization by being cognizant of the how they utilize power.

Bolman and Deal (2008) identify four major tenants within the human resource frame: (a) organizations exist to serve and meet the needs of people, (b) people and organizations are interdependent, (c) if fit between individual and organization is poor both suffer, and (d) a good fit benefits both. Principals understanding how they impact teachers' sense of professionalism are better equipped to provide them with the necessary opportunities to keep them connected and engaged within the organizations.

Principals can begin to gain an understanding of how their use of power could potentially grow or hinder their teacher's growth and self-perception of professionalism. Principals' have an obligation to not only establish an environment conducive to learning for students, but to foster a professional learning environment that observes the teacher as 
a professional both in action and in means of leadership as it pertains to the principals' use of power.

\section{Recommendation for Future Research}

This study was conducted utilizing a convenience sample of schools located in the Southwest Missouri and part of the Central Ozark Conference (COC). The sample size of this study included 1,276 high school certified teachers. Although the sample size was significant enough to accommodate the type of data analysis that was executed, the limited response rate prevented the researcher from conducting a multiple regression means of looking at the relationship between the two variables: power and professionalism. A larger sample size, extended window of time for data collection, and high school principal input could provide both a great response rate and a more accurate assessment of the interaction between the principals' use of power and the teacher's selfperception of professionalism.

Increasing the sample size from 1,276 to the approximately 20,020 certified secondary teachers within the state of Missouri as identified by the Department of Elementary and Secondary Education (DESE, 2014) and extending the window of time for data collection could possibly increase the amount of responses. Furthermore, taking into account the principals self-perception of power and use of power would provide for further data to allow for comparison between the teachers' perception of their principals' use of power as well as the principals' self-perception of their own use of power. Finally, adding a component of qualitative data, such as teacher interviews and principal interviews, could allow for the triangulation of data to take place. 


\section{Conclusion}

Having a strong understanding of the relationship that exists between the principal and the teacher is important when understanding what components effect teacher professionalism in education. This quantitative study sought to explore the relationship between the principals' use of power and the teacher's self-perception of professionalism. Prior to the human resource theory the purpose of the organization as an entity was to achieve, by any means, its mission and its purpose. Neglected in this process were the people who made up the organization. The human resource frame (Bolman \& Deal, 2008) articulated the importance of the relationship between the organization and those involved in the make-up of the organization. The purpose of the organization evolved to one that began to meet the needs of individuals and fulfill their own professional goals and purpose resulting in both organizational and participant satisfaction.

It was the intention of this researcher to examine the relationship between the principals' use of power and the teacher's self-perception of professionalism with the purpose of identifying how the principal supports or distracts from the teachers' sense of professionalism. While the limited response rate affected this researchers' ability to make conclusions that included any statistical significance, it was evident that teachers' in the Central Ozark Conference, for the most part, perceived their principal's use of power with positive regard as well as their self-perception professionalism. 


\section{References}

Agarwala, T. (2002). Human resource management: The emerging trends. Indian Journal of Industrial Relations, 37(3), 315-331.

Bolman, L. G., \& Deal, T. E. (2008). Reframing organizations: Artistry, choice, and leadership (4th ed.). San Francisco, CA: Jossey-Bass.

Burnette, N. P. (1992). A descriptive study of the power bases used by North Carolina Principals (Doctoral dissertation). Retrieved from ProQuest. (304018778).

Cheng, Y. C. (1996). Relation between teachers' professionalism and job attitudes, educational outcomes, and organizational factors. Journal of Educational Research, 89(3), 163-171.

Cramer, S. R. (1996). Assumptions central to quality movement in education. The Clearing House, 69(6), 360-364.

Creswell, J. W. (2009). Research design: Qualitative, quantitative, and mixed methods Approaches (3rd ed., pp. 49-61). Thousand Oaks, CA: Sage.

D'Amico, D. (2010). Claiming profession: The dynamic struggle for teacher professionalism in the twentieth century (Doctoral dissertation). Retrieved from ProQuest. (763608149).

Department of Elementary and Secondary Education. (2013). 2012-2013 statistics of Missouri public schools. Retrieved May 20, 2014, from http://mcds.dese.mo.gov/quickfacts/Missouri\%20School\%20Directory/2014/Miss ouri\%20School\%20Statistics.pdf. 
DeRose, M. N. (1985). A study of the relationship between perceived power use by secondary school principals and the degree of teacher alienation in school situations perceived by their principals as stressful-influence, authority, involvement (Doctoral dissertation). Retrieved from ProQuest. (303396775).

DuFour, R., \& Eaker, R. (1998). Professional learning communities at work: Best practices for enhancing student achievement. Bloomington, IN: National Education Service.

Edstam, T. S. (1998). Perceptions of professionalism among elementary school english as a second language teachers (Doctoral dissertation) Retrieved from ProQuest. (304435869).

Eisenmann, L. (1991). Teacher professionalism: A new analytical tool for the history of teachers. Harvard Educational Review, 61(2), 215-224.

Evans, L. (2008). Professionalism, professionality and the development of education professionals. British Journal of Educational Studies, 56(1), 20-38.

Field, A. (2009). Discovering statistics using SPSS (3rd ed.). Los Angeles, CA: Sage.

Fink, A. (2009). How to conduct surveys: A step-by-step guide (4th ed.). Los Angeles, CA: Sage.

French, J. R. P., \& Raven, B. (2011). The bases of social power. In J. M. Shafritz, J. S. Ott, \& Y. S. Yang (Eds.), Classics of organizational theory (7th ed., pp. 298-306). Boston, MA: Wadsworth. (Reprinted from Studies in social power, ed. Dorwin P. Cartwright. pp. 150-167, Ann Arbor, MI: Institute for Social Research, University of Michigan, 1959) 
Furlong, J. (2005). New labour and teacher education: The end of an era. Oxford Review of Education, 31(1), 119-134.

Hendriks, M, Luyten, H., Scheerens, J., Sleegers, P., \& Steen, R. (2010). Teacher professional development: An analysis of teachers' professional development based on OECD's teaching and learning international survey. Retrieved from http://www.dgeec.mec.pt/np4/105/\%7B\$clientServletPath\%7D/?newsId=157\&fil eName=Teachers__Professional_Development.pdf

Hersey, P., Blanchard, H., \& Natemeyer, W. E. (1979). Situational leadership, perception, and the impact of power. Group and Organization Management 4(4), 418-428. doi: 10.1177/105960117900400404.

Hersey, P., \& Natemeyer, W. (1988). Power Perception Profile. Escondido, CA: Center for Leadership Studies.

Hilferty, F. (2008). Theorizing teacher professionalism as an enacted discourse of power. British Journal of Sociology of Education, 29(2), 161-173. doi: $10.1080 / 01425690701837521$.

Hiltz, G. (1992). Professionalism: Perceptions of New Hampshire educators (Doctoral dissertation). Retrieved from ProQuest. (303990185).

King, B., \& Kerchner, C. T. (1991). Defining principal leadership in an era of teacher Empowerment (Doctoral Dissertation). Retrieved from ProQuest.

Lymas, L. W. (1992). A study of the use of power by middle school and high school principals and its relationship to teacher satisfaction with work and with principal (Doctoral dissertation). Retrieved from ProQuest. (304019567). McGregor, D. (1960). The human side of enterprise. New York: McGraw-Hill. 
McMahon, E. M. (2007). Professionalism in teaching: An individual level measure for a structural theory (Doctoral dissertation). Retrieved from ProQuest. (304821497).

Northouse, P. G. (2010). Leadership: Theory and practice (5th ed.). Los Angeles: Sage.

Raven, B. H., \& Kruglanski, W. (1975). Conflict and power. In P. G. Swingle (Ed.), The structure of conflict. New York: Academic Press.

Robinson, T. (2008). The relationship between teacher self-perception of professionalism and professional learning community characteristics (Doctoral dissertation). University of Missouri, Missouri.

Russ, T. L. (2011). Theory X/Y assumptions as predictors of managers' propensity for participative decision making. Management Decisions, (49)5, 823-836.

Schultz, I. D. L. (1986). A study of the relationship of teachers' job satisfaction and their perceptions of principals' use of power and organizational effectiveness (Doctoral dissertation). Retrieved from ProQuest. (303430976).

Smylie, M. A. (1992). Teacher participation in school decision making: Assessing willingness to participate. Educational Evaluation and Policy Analysis. 14(1), 53-67.

Snizek, W. E. (1972). Hall's professionalism scale: An empirical reassessment. American Sociological Review 37(1), 109-114.

Sockett, H. (1993). The moral base for teacher professionalism. New York: Teachers College Press.

Stroh, L. K. (1986). Student evaluation of teachers the impact on teacher effectiveness and professionality (Doctoral dissertation). Retrieved from ProQuest. (303432403). 
Sun, L., Aryee, S., and Law, K. S. (2007). High-performance human resource practices, citizenship behavior, and organizational performance: A relational perspective. The Academy of Management Journal 50(3), 558-557.

Taylor, F. W. (2011). The principles of scientific management. In J. M. Shafritz, J. S. Ott, \& Y. S. Yang (Eds.), Classics of organizational theory $\left(7^{\text {th }}\right.$ ed., pp. 65-76). Boston, MA: Wadsworth. (Reprinted from Bulletin of the Taylor Society. December, 1916)

Tichenor, M., \& Tichenor, J. (2005). Understanding teachers' perspectives on professionalism. Professional Educator, 27(1-2), 89-95.

Tichenor, M., \& Tichenor, J. (2009) Comparing teacher and administrator perspectives on multiple dimensions of teacher professionalism. Journal of Southeastern Regional Association of Teacher Educators, 18(2), 9-18.

Troman, G. (1996). The rise of the new professionals? The restructuring of primary teachers' work and professionalism. British Journal of Sociology of Education, 17(4), 473-487.

Warrend, D. I. (1969). The effects of power bases and peer groups on conformity in formal organizations. Administrative Science Quarterly, 14(4), 544-556.

Willower, D. J. (1960). Professionalization and education. Peabody Journal of Education, 38(2), 73-78. 


\section{Appendices}

\section{Appendix A: Power and Professionalism Inventory}

The Power and Professionalism Inventory is the Teacher Professionalism Inventory Self (Appendix A) and the Power Perception Profile-Perception of Other (Appendix C) combined together and placed online to be disseminated to the sample group. 
Appendix B: Teacher Professionalism Inventory of Self

\begin{tabular}{|c|c|c|c|c|c|c|c|}
\hline & $\begin{array}{r}\text { TEACHER PRC } \\
\text { Adapted from the work of } T\end{array}$ & $\begin{array}{l}\text { FESSIC } \\
\text { chenor anc }\end{array}$ & $\begin{array}{l}\text { NALIS } \\
\text { Tichenor }\end{array}$ & $\begin{array}{l}1 \text { INVEN } \\
\text { 05); Cheng }\end{array}$ & $\begin{array}{l}\text { TORY - } \\
\text { 1996); and } S\end{array}$ & $\begin{array}{l}\text { ELF } \\
\operatorname{cket}(19)\end{array}$ & \\
\hline \# & QUESTION/STATEMENT & $\begin{array}{l}\text { Strongly } \\
\text { Disagree } \\
\end{array}$ & Disagree & $\begin{array}{l}\text { Somewhat } \\
\text { Disagree }\end{array}$ & $\begin{array}{c}\text { Somewhat } \\
\text { Agree }\end{array}$ & Agree & $\begin{array}{c}\text { Strongly } \\
\text { Agree }\end{array}$ \\
\hline 1 & $\begin{array}{l}\text { It is important to me to dress } \\
\text { in a neat manner. }\end{array}$ & $\mathbf{0}$ & $\mathbf{0}$ & $\mathbf{0}$ & $\mathbf{0}$ & $\mathbf{0}$ & $\mathbf{0}$ \\
\hline 2 & $\begin{array}{l}\text { I exhibit confidence in my } \\
\text { teaching on a daily basis. }\end{array}$ & $\mathbf{0}$ & $\mathbf{0}$ & 0 & $\mathbf{0}$ & 0 & 0 \\
\hline 3 & $\begin{array}{l}\text { I put the welfare of students } \\
\text { before personal interests. }\end{array}$ & $\mathbf{0}$ & $\mathbf{0}$ & 0 & $\mathbf{0}$ & $\mathbf{0}$ & $\mathbf{0}$ \\
\hline 4 & $\begin{array}{l}\text { I display enthusiasm for } \\
\text { teaching. }\end{array}$ & $\mathbf{0}$ & $\mathbf{0}$ & 0 & $\mathbf{0}$ & $\mathbf{0}$ & $\mathbf{0}$ \\
\hline 5 & $\begin{array}{l}\text { I behave in an ethical manner } \\
\text { in and out of school }\end{array}$ & 0 & 0 & 0 & 0 & 0 & $\mathbf{0}$ \\
\hline 6 & $\begin{array}{l}\text { I regard the education of } \\
\text { students as my primary duty. }\end{array}$ & O & 0 & 0 & 0 & 0 & 0 \\
\hline 7 & $\begin{array}{l}\text { I see myself as a life-long } \\
\text { learner. }\end{array}$ & $\mathbf{0}$ & 0 & $\mathbf{0}$ & 0 & $\mathbf{0}$ & 0 \\
\hline 8 & $\begin{array}{l}\text { I respect students and their } \\
\text { ideas. }\end{array}$ & 0 & $\mathbf{0}$ & 0 & 0 & $\mathbf{0}$ & 0 \\
\hline 9 & $\begin{array}{l}\text { I look forward to coming to } \\
\text { school each day. }\end{array}$ & 0 & 0 & $\mathbf{0}$ & $\mathbf{0}$ & 0 & 0 \\
\hline 10 & $\begin{array}{l}\text { I exhibit personal } \\
\text { responsibility for the quality } \\
\text { of my own teaching. }\end{array}$ & 0 & 0 & 0 & 0 & 0 & 0 \\
\hline 11 & $\begin{array}{l}\text { I set high standards for self } \\
\text { and students }\end{array}$ & 0 & 0 & 0 & 0 & 0 & 0 \\
\hline 12 & $\begin{array}{l}\text { I maintain composure in all } \\
\text { school-related situations. }\end{array}$ & 0 & 0 & 0 & 0 & 0 & 0 \\
\hline 13 & $\begin{array}{l}\text { I select teaching strategies } \\
\text { based on best practices in } \\
\text { education and current } \\
\text { research findings }\end{array}$ & 0 & 0 & 0 & 0 & 0 & 0 \\
\hline 14 & $\begin{array}{l}\text { I am dedicated to teaching as } \\
\text { a life-long career }\end{array}$ & 0 & 0 & 0 & 0 & 0 & 0 \\
\hline 15 & $\begin{array}{l}\text { I make presentations at } \\
\text { seminars, workshops, and/or } \\
\text { conference. }\end{array}$ & 0 & 0 & 0 & 0 & 0 & 0 \\
\hline 16 & $\begin{array}{l}\text { I am willing to lead a new } \\
\text { team in my school setting to } \\
\text { address areas of student } \\
\text { need. }\end{array}$ & 0 & 0 & 0 & 0 & 0 & 0 \\
\hline 17 & $\begin{array}{l}\text { I contribute to the } \\
\text { professional growth of my } \\
\text { colleagues. }\end{array}$ & 0 & 0 & 0 & 0 & 0 & 0 \\
\hline 18 & $\begin{array}{l}\text { I actively seek professional } \\
\text { development opportunities. }\end{array}$ & 0 & 0 & 0 & 0 & 0 & 0 \\
\hline 19 & $\begin{array}{l}\text { I experiment with innovative } \\
\text { teaching practices. }\end{array}$ & 0 & 0 & 0 & 0 & 0 & 0 \\
\hline 20 & $\begin{array}{l}\text { I keep up with current social } \\
\text { and political trends affecting } \\
\text { education. }\end{array}$ & 0 & 0 & 0 & 0 & 0 & 0 \\
\hline
\end{tabular}




\begin{tabular}{|c|c|c|c|c|c|c|c|}
\hline \multicolumn{8}{|c|}{$\begin{array}{l}\text { TEACHER PROFESSIONALISM INVENTORY - SELF } \\
\text { Adapted from the work of Tichenor and Tichenor (2005); Cheng (1996); and Socket (1993) }\end{array}$} \\
\hline \# & QUESTION/STATEMENT & $\begin{array}{l}\text { Strongly } \\
\text { Disagree }\end{array}$ & Disagree & $\begin{array}{c}\text { Somewhat } \\
\text { Disagree }\end{array}$ & $\begin{array}{l}\text { Somewhat } \\
\text { Agree }\end{array}$ & Agree & $\begin{array}{l}\text { Strongly } \\
\text { Agree }\end{array}$ \\
\hline 21 & $\begin{array}{l}\text { I regularly observe other } \\
\text { teachers to improve my own } \\
\text { teaching. }\end{array}$ & $\mathbf{0}$ & $\mathbf{O}$ & $\mathbf{0}$ & $\mathbf{0}$ & $\mathbf{0}$ & $\mathbf{0}$ \\
\hline 22 & $\begin{array}{l}\text { I remain receptive to new } \\
\text { ideas and change. }\end{array}$ & $\mathbf{0}$ & $\mathbf{0}$ & $\mathbf{0}$ & $\mathbf{0}$ & 0 & $\mathbf{0}$ \\
\hline 23 & $\begin{array}{l}\text { I engage in teacher research } \\
\text { or action research to improve } \\
\text { own practice. }\end{array}$ & $\mathbf{0}$ & $\mathbf{0}$ & $\mathbf{0}$ & $\mathbf{0}$ & 0 & $\mathbf{0}$ \\
\hline 24 & $\begin{array}{l}\text { I teach in developmentally } \\
\text { appropriate ways. }\end{array}$ & $\mathbf{0}$ & $\mathbf{0}$ & $\mathbf{0}$ & 0 & $\mathbf{0}$ & $\mathbf{0}$ \\
\hline 25 & $\begin{array}{l}\text { I understand the } \\
\text { developmental needs of } \\
\text { children. }\end{array}$ & 0 & $\mathbf{0}$ & $\mathbf{0}$ & 0 & $\mathbf{0}$ & $\mathbf{0}$ \\
\hline 26 & $\begin{array}{l}\text { I make classroom decisions } \\
\text { based on the needs of } \\
\text { students. }\end{array}$ & $\mathbf{0}$ & $\mathbf{0}$ & $\mathbf{0}$ & $\mathbf{0}$ & $\mathbf{0}$ & $\mathbf{0}$ \\
\hline 27 & $\begin{array}{l}\text { I know and apply human } \\
\text { development and learning } \\
\text { theories. }\end{array}$ & 0 & $\mathbf{0}$ & $\mathbf{0}$ & O & $\mathbf{0}$ & $\mathbf{0}$ \\
\hline 28 & $\begin{array}{l}\text { I regularly evaluate my own } \\
\text { choices and actions in the } \\
\text { classroom. }\end{array}$ & $\mathbf{0}$ & $\mathbf{0}$ & $\mathbf{0}$ & $\mathbf{0}$ & 0 & 0 \\
\hline 29 & $\begin{array}{l}\text { I possess a high degree of } \\
\text { content knowledge in my } \\
\text { areas of certification. }\end{array}$ & $\mathbf{0}$ & $\mathbf{0}$ & $\mathbf{0}$ & $\mathbf{0}$ & $\mathbf{0}$ & $\mathbf{0}$ \\
\hline 30 & $\begin{array}{l}\text { I possess a high degree of } \\
\text { pedagogical knowledge. }\end{array}$ & $\mathbf{0}$ & 0 & 0 & 0 & 0 & 0 \\
\hline 31 & $\begin{array}{l}\text { I consider all aspects of the } \\
\text { students I teach. }\end{array}$ & 0 & 0 & 0 & 0 & 0 & 0 \\
\hline 32 & $\begin{array}{l}\text { I create a positive learning } \\
\text { environment for students. }\end{array}$ & 0 & 0 & 0 & 0 & 0 & 0 \\
\hline 33 & $\begin{array}{l}\text { I serve as a positive role } \\
\text { model for students and } \\
\text { colleagues. }\end{array}$ & 0 & 0 & 0 & 0 & 0 & 0 \\
\hline 34 & $\begin{array}{l}\text { I actively participate on } \\
\text { school-wide committees } \\
\text { and/or in school decision } \\
\text { making. }\end{array}$ & 0 & 0 & 0 & 0 & 0 & 0 \\
\hline 35 & $\begin{array}{l}\text { I share teaching strategies } \\
\text { and ideas with colleagues. }\end{array}$ & 0 & 0 & 0 & 0 & 0 & 0 \\
\hline 36 & $\begin{array}{l}\text { I establish friendly and } \\
\text { cooperative relationships } \\
\text { with parents. }\end{array}$ & 0 & 0 & 0 & 0 & 0 & 0 \\
\hline 37 & $\begin{array}{l}\text { I cooperative with colleagues } \\
\text { in the interest of students. }\end{array}$ & 0 & 0 & 0 & 0 & 0 & 0 \\
\hline 38 & $\begin{array}{l}\text { I show respect for colleagues } \\
\text { and administrators. }\end{array}$ & 0 & 0 & 0 & 0 & 0 & 0 \\
\hline 39 & $\begin{array}{l}\text { I help foster a positive } \\
\text { working environment within } \\
\text { the school. }\end{array}$ & 0 & 0 & 0 & 0 & 0 & 0 \\
\hline
\end{tabular}




\begin{tabular}{|c|l|c|c|c|c|c|c|}
\hline \multicolumn{8}{|c|}{ TEACHER PROFESSIONALISM INVENTORY - SELF } \\
\hline$\#$ & QuESTION/STATEMENT & $\begin{array}{c}\text { Strongly } \\
\text { Disagree }\end{array}$ & Disagree & $\begin{array}{c}\text { Somewhat } \\
\text { Disagree }\end{array}$ & $\begin{array}{c}\text { Somewhat } \\
\text { Agree }\end{array}$ & Agree & $\begin{array}{c}\text { Strongly } \\
\text { Agree }\end{array}$ \\
\hline 40 & $\begin{array}{l}\text { I discuss teaching } \\
\text { philosophies with colleagues. }\end{array}$ & $\mathbf{0}$ & $\mathbf{0}$ & $\mathbf{0}$ & $\mathbf{0}$ & $\mathbf{0}$ & $\mathbf{0}$ \\
\hline 41 & $\begin{array}{l}\text { I mentor or am willing to } \\
\text { mentor beginning and } \\
\text { experienced teachers. }\end{array}$ & $\mathbf{0}$ & $\mathbf{0}$ & $\mathbf{0}$ & $\mathbf{0}$ & $\mathbf{0}$ & $\mathbf{0}$ \\
\hline 42 & $\begin{array}{l}\text { I stay actively involved in } \\
\text { professional organizations } \\
\text { for educators. }\end{array}$ & $\mathbf{0}$ & $\mathbf{0}$ & $\mathbf{0}$ & $\mathbf{0}$ & $\mathbf{0}$ & $\mathbf{0}$ \\
\hline 43 & $\begin{array}{l}\text { I participate in curriculum } \\
\text { development. }\end{array}$ & $\mathbf{0}$ & $\mathbf{0}$ & $\mathbf{0}$ & $\mathbf{0}$ & $\mathbf{0}$ & $\mathbf{0}$ \\
\hline
\end{tabular}


Appendix C: Power Perception Profile

\section{POWER PERCEPTION PROFILE-PERCEPTION OF OTHER}

Listed below are 21 pairs of reasons often given by people when they are asked why they do the things that their principal suggests or wants them to do. Allocate 3-points between the two alternative reasons in each pair. Base your point allocation on your judgment of each alternative's relative importance ( $0=$ Not important to $3=$ Very Important). This is in reference to your perception of why you comply with your principal. Remember, for each pair only allocate a total number of three points.

\begin{tabular}{ll|l|l|l}
\multirow{1}{*}{1} & $\mathbf{A}$ & & My principal can administer sanctions and punishments to those who do not cooperate. \\
\cline { 2 - 4 } & $\mathbf{B}$ & & I realize that my principal has connections with influential and important persons.
\end{tabular}

\begin{tabular}{l|l|l|l}
$\mathbf{2}$ & $\mathbf{C}$ & & I respect my principal's understanding, knowledge, judgment, and experience. \\
\hline & $\mathbf{D}$ & & My principal possesses or has access to information that is valuable to others.
\end{tabular}

\begin{tabular}{c|c|c|c|}
3 & $\mathbf{E}$ & & My principal's position in the organization provides him/her the authority to direct my work activities. \\
\cline { 2 - 4 } & $\mathbf{F}$ & I like my principal and want to do things that please him/her.
\end{tabular}

4 G $\quad$ My principal can provide rewards and support to those who cooperate.

A My principal can administer sanctions and punishments to those who do not cooperate.

5 B $\quad$ I realize that my principal has connections with influential and important persons.

I respect my principal's understanding, knowledge, judgment, and experience.

\begin{tabular}{ll|l|l}
6 & $\mathbf{D}$ & & My principal possesses or has access to information that is valuable to others. \\
\cline { 2 - 4 } & $\mathbf{E}$ & & My principal's position in the organization provides him/her the authority to direct my work activities.
\end{tabular}

7 F $\quad$ I like my principal and want to do things that please him/her.

G My principal can provide rewards and support to those who cooperate.

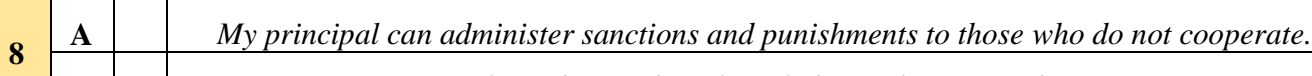

C I respect my principal's understanding, knowledge, judgment, and experience.

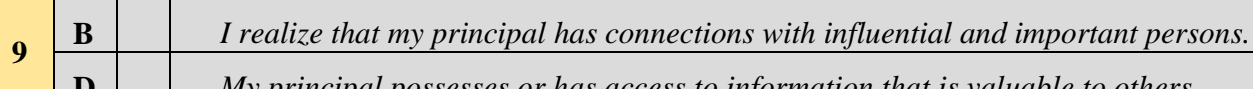

D My principal possesses or has access to information that is valuable to others.

\begin{tabular}{c|c|c|c|}
\multirow{2}{1}{10} & $\mathbf{C}$ & & I respect my principal's understanding, knowledge, judgment, and experience. \\
\cline { 2 - 5 } & $\mathbf{E}$ & & My principal's position in the organization provides him/her the authority to direct my work activities.
\end{tabular}

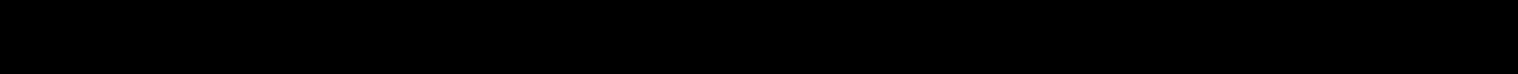

\begin{tabular}{l|l|l|l|}
\multirow{2}{*}{11} & D & & My principal possesses or has access to information that is valuable to others. \\
\cline { 2 - 4 } & A & & My principal can administer sanctions and punishments to those who do not cooperate.
\end{tabular} 


\begin{tabular}{|c|c|c|c|}
\hline \multirow{2}{*}{12} & $\mathbf{E}$ & & My principal's position in the organization provides him/her the authority to direct my work activities. \\
\hline & B & & I realize that my principal has connections with influential and important persons. \\
\hline \multirow{2}{*}{13} & $\mathbf{F}$ & & I like my principal and want to do things that please him/her. \\
\hline & $\mathbf{C}$ & & I respect my principal's understanding, knowledge, judgment, and experience. \\
\hline \multirow{2}{*}{14} & G & & My principal can provide rewards and support to those who cooperate. \\
\hline & B & & I realize that my principal has connections with influential and important persons. \\
\hline \multirow{2}{*}{15} & A & & My principal can administer sanctions and punishments to those who do not cooperate. \\
\hline & $\mathbf{E}$ & & My principal's position in the organization provides him/her the authority to direct my work activities. \\
\hline \multirow{2}{*}{16} & B & & I realize that my principal has connections with influential and important persons. \\
\hline & $\mathbf{F}$ & & I like my principal and want to do things that please him/her. \\
\hline \multirow{2}{*}{17} & $\mathbf{C}$ & & I respect my principal's understanding, knowledge, judgment, and experience. \\
\hline & G & & My principal can provide rewards and support to those who cooperate. \\
\hline \multirow{2}{*}{18} & D & & My principal possesses or has access to information that is valuable to others. \\
\hline & $\mathbf{F}$ & & I like my principal and want to do things that please him/her. \\
\hline \multirow{2}{*}{19} & $\mathbf{E}$ & & My principal's position in the organization provides him/her the authority to direct my work activities. \\
\hline & G & & My principal can provide rewards and support to those who cooperate. \\
\hline \multirow{2}{*}{20} & $\mathbf{F}$ & & I like my principal and want to do things that please him/her. \\
\hline & A & & My principal can administer sanctions and punishments to those who do not cooperate. \\
\hline \multirow{2}{*}{21} & G & & My principal can provide rewards and support to those who cooperate. \\
\hline & D & & My principal possesses or has access to information that is valuable to others. \\
\hline & A & $\mathbf{0}$ & Coercive Power \\
\hline & B & $\mathbf{0}$ & Connection Power \\
\hline & C & $\mathbf{0}$ & Expert Power \\
\hline & D & $\mathbf{0}$ & Information Power \\
\hline & $\mathbf{E}$ & $\mathbf{0}$ & Legitimate Power \\
\hline & $\mathbf{F}$ & $\mathbf{0}$ & Referent Power \\
\hline & G & $\mathbf{0}$ & Reward Power \\
\hline & & & Adapted from Paul Hersey and Walter E. Natemeyer (1979) \\
\hline
\end{tabular}


Appendix D: Introductory Letter to the High School Principal

DATE

High School Principal Name

School District/High School

Street Name

City, State and Zip Code

I am doctoral student and I am currently working toward a degree with the University of Missouri - Columbia in the Education Leadership and Policy Analysis Program. I would like to complete a quantitative study examining the relationship between the principal's use of power and teacher's self-perception of professionalism. My dissertation will be in partial fulfillment of doctoral course work at the University of Missouri - Columbia. The working title of my dissertation is: THE RELATIONSHIP BETWEEN THE PRINCIPALS USE OF POWER AND TEACHERS SELF-PERCEPTION OF PROFESSIONALISM. I will work under the advisement of Dr. Cynthia MacGregor who can be contacted at 417-836-6046 should you have any questions or concerns.

The purpose of this study is to examine the relationship between the principals use of power and teachers self-perception of professionalism. Upon approval of both the superintendent and the high school principal, a template email will be provided to the high school principal to be disseminated to all certified secondary classroom teachers that contains an: introduction to the study, link to the survey with an informed consent imbedded on the first window. Participation is voluntary and answers will remain anonymous. You may request an executive summary of my findings if you wish by contact me via email at the below provided contact information.

By providing your signature below you are granting permission for me, Travis Graham to administer the online survey The Power and Professionalism Inventory (TPPI) to all certified faculty at (HIGH SCHOOL NAME). Furthermore you are granting permission for the information gathered from TPPI to be utilized in the above named dissertation.

Name-Print

Name - Signature

Date-mm/dd/year

Sincerely,

Travis Graham, Research Investigator-Co-Worker

University of Missouri - Columbia

Educational Leadership and Policy Analysis: Ed.D.

Phone: 417-527-8163

Email: tgraham@hollister.k12.mo.us 


\section{Appendix E: Introduction \& Informed Consent - Teachers}

Dear Educator:

I am doctoral student and I am currently working toward a degree with the University of Missouri - Columbia Education Leadership and Policy Analysis Program. I would like to complete a quantitative research study examining the relationships between the principal's use of power and teacher's self-perception of professionalism. My dissertation will be in partial fulfillment of doctoral course work at the University of Missouri - Columbia. The working title of my dissertation is: THE RELATIONSHIP BETWEEN THE HIGH SCHOOLS PRINCIPALS' USE OF POWER AND TEACHER'S SELF-PERCEPTION OF PROFESSIONALISM. I request your permission to participate in this research study by filling out an online survey concerning your views of yourself as a professional and your principal's use of power. The survey will take approximately 30 minutes to complete and will be open for a period of two weeks. Prior to you making a final decision to participate, please read the following concerning your rights as a participant:

Your answers will remain anonymous. The only identifying materials collected pertain to your demographic information and concern your specific teaching experiences. Data collected will be maintained and stored for a period of seven years once the study is complete. The data you provide will be summarized for reporting. I will act as the caretaker of all data and will be the only person with access to identifiable data. Your name cannot be attributed to the survey you submit.

Participation is voluntary. You may withdraw at any time. If, through the online survey process, you wish to withdraw from the study there will be an option to do so provided on the online survey. Refusal to participate will have no adverse consequences. For any questions about your participation, please contact me at (417) 527-8163 or by electronic mail at tgraham@ hollister.k12.mo.us, or my advisor Dr. Cynthia MacGregor at (417) 836-6046 or by electronic mail at CMacGregor@MissouriState.edu.

You control how much information you wish to provide and this insures that there will be no identifiable risk greater than that encountered in everyday life. If you have any questions concerning your rights as a human subject please do not hesitate to University of Missouri Campus IRB at (573) 882-9585.

The survey should take approximately 30 minutes. Additionally, you may request an executive summary of my findings. If you wish to receive an executive summary of my findings please use contact information provided on this page. Thank you for your consideration; my learning relies on the input of professionals like you.

Sincerely,

Travis Graham -Doctoral Student and Assistant Principal, Hollister High School, Hollister, Missouri.

\section{INFORMED CONSENT FROM SURVEY PARTICIPANT}

I agree to participate in the study described above conducted by Travis Graham, doctoral student at the University of Missouri - Columbia. I understand the following:

- My participation is voluntary, and may be withdrawn at any point.

- My responses will be used in partial fulfillment of a doctoral degree requirement; the research study will be published and disseminated outside the regular classroom.

- My identity and affiliation will be kept anonymous. I have read the statement above, which answered my questions completely.

By selecting CONTINUE you are providing an electronic signature and your INFORMED CONSENT to participate in the above described study. If at any time during this survey you wish to withdraw participation, please select the I WISH TO WITHDRAW selection which will exit you from the survey tool. Your participating in this study is valuable and appreciated. If you have any questions please do not hesitate to contact me via email at: tgraham@hollister.k12.mo.us 


\section{Appendix F: Principal Permission Request to Conduct Research}

\section{Principal Permission Request to Conduct Research}

\section{Dear COC High School Principal,}

The purpose of this letter is to request your permission to conduct research utilizing certified high school teachers from your building. The working title of my dissertation is: THE RELATIONSHIP BETWEEN THE HIGH SCHOOL PRINCIPALS' USE OF POWER AND THE TEACHER'S SELF-PERCEPTION OF PROFESSIONALISM.

The purpose of this study is to examine the relationship between the principals' use of power and the teacher's selfperception of professionalism A survey titled, The Power and Professionalism Inventory (TPPI) will be utilized to collect data. The survey is intended for all certified faculty to complete online and will be distributed by the building administrator electronically by forwarding an introductory email with a link to the survey.

By providing your electronic signature below you are agreeing to participate in my study by distributing the survey, TPPI, to all certified faculty members at your high school Furthermore you are granting permission for the information gathered from the TPPI to be utilized in the above named dissertation research project. The project will be conducted after approval from the University of Missouri IRB (573) 882-9585.

Sincerely,

Travis W. Graham

University of Missouri - Cohmbia

HIGH SCHOOL
FIRST NAME
LAST NAME
DATE
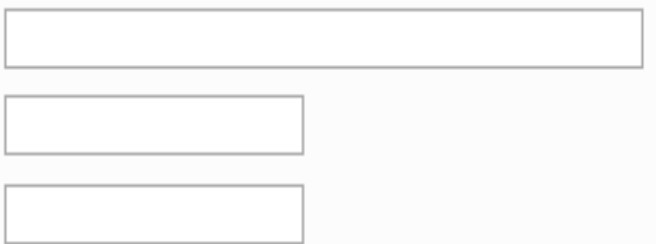

DATE 
VITA

Travis W. Graham was born in Louisiana and raised in Washington State with his older brother. He began his collegiate career at College of the Ozarks where he graduated with a bachelor of science in K-12 vocal music education. He completed his initial master's degree at Missouri State University in music education with an emphasis in secondary education. During this time he married and embarked on another journey of completing a master's degree in educational administration. Travis served as a vocal music educator for nine years which led him to pursue his doctorate degree in educational leadership. While completing his doctorate degree through the University of MissouriColumbia, Travis started serving as an assistant principal, and did for two years before becoming a high school building principal in a small Missouri school district. Travis continues to pursue leadership opportunities in the South Central Missouri region and looks forward to continuing serving in the field of education. 